FROM COMMUNITY INSTITUTION TO CONDO CONVERSION:

ADAPTIVE REUSE WITHIN NEIGHBOURHOOD GENTRIFICATION IN CITIES IN ONTARIO

\author{
by \\ Emma Abramowicz \\ B.A. (Honours), Queen's University, 2013 \\ A Major Research Paper \\ presented to Ryerson University \\ in partial fulfillment of the requirements for the degree of \\ Master of Planning \\ in \\ Urban Development
}

Toronto, Ontario, Canada, 2016

(C) Emma Abramowicz, 2016 


\section{AUTHOR'S DECLARATION FOR ELECTRONIC SUBMISSION OF AN MRP}

I hereby declare that I am the sole author of this MRP. This is a true copy of the MRP, including any required final revisions.

I authorize Ryerson University to lend this MRP to other institutions or individuals for the purpose of scholarly research.

I further authorize Ryerson University to reproduce this MRP by photocopying or by other means, in total or in part, at the request of other institutions or individuals for the purpose of scholarly research.

I understand that my MRP may be made electronically available to the public 


\title{
FROM COMMUNITY INSTITUTION TO CONDO CONVERSION: ADAPTIVE REUSE WITHIN NEIGHBOURHOOD GENTRIFICATION IN CITIES IN ONTARIO
}

\author{
(C) Emma Abramowicz, 2016 \\ Master of Planning \\ in \\ Urban Development \\ Ryerson University
}

\begin{abstract}
What role do school and church condominium conversions play in processes of neighbourhood change? This paper examines 40 residential condominium conversions of former neighbourhood institutions in Ontario's three largest urban municipalities to determine their role within local gentrification processes. The research analyzes indicator data over time in each conversion neighbourhood to identify gentrification trends and the points at which the conversions are proposed within or outside them. The research finds that post-institutional conversions can fall at any point before, during, after or outside neighbourhood gentrification. This paper concludes that such conversions do not play a universal driving or reactive role, however they have the power to foster further gentrification where they occur early in the process. Planners are thus encouraged to consider facilitating alternatives to private conversion in particular neighbourhood contexts. Further research is recommended on the intersection of heritage conservation, adaptive reuse and neighbourhood gentrification.
\end{abstract}

Key words: adaptive reuse; gentrification; school conversions; church conversions; heritage planning 


\section{ACKNOWLEDGEMENTS}

I'd like to thank two particular guiding influences for this paper: first, my supervisor, Dr. Mitchell Kosny, for trusting my instincts throughout this venture and others, but most of all for selling me on this incredible program back in 2013. Second, to Dr. Gary Miedema, who offered valuable critical insight toward this paper, and who first introduced me to the heritage planning world. I also want to thank Kaitlin Wainwright, whose helpful research suggestions managed to make this project feel a little less overwhelming.

A massive acknowledgement goes to my classmates. I can't even begin to explain how special these two years have been. You are all so intelligent, motivated and interesting, and it's been amazing to be part of such a close, supportive, super keen community. (Particular shout-outs for all the trivia and the rail-based board games.) I couldn't have been luckier.

This research is ultimately dedicated to my parents and to Brendan, who've motivated me to be driven, to think (and argue) critically, and to work hard enough to make up for the gravy train.

To my café study buddies over the years, without whom I wouldn't have survived these six years of university. And to Geoff, who for some reason continues to be so patient, supportive and accepting while I live and breathe school - now you have my full attention, and always all of my love. 


\section{TABLE OF CONTENTS}

1.0 INTRODUCTION 1

1.1 Research Question 2

1.2 Overview of this Paper 3

2.0 CONTEXT

2.1 Adaptive Reuse

2.2 Intersecting Heritage and Gentrification 6

2.3 Corporatizing Gentrification in the $21^{\text {st }}$ Century 8

3.0 LITERATURE REVIEW

$\begin{array}{ll}3.1 \text { Literature on Adaptive Reuse } & 11\end{array}$

3.1.1 Divergent Perspectives on Adaptive Reuse 13

3.2 A Brief Overview of Gentrification Literature 15

3.2.1 Production and Consumption Explanations of Gentrification 16

3.2.2 Gentrification in a Local Context 18

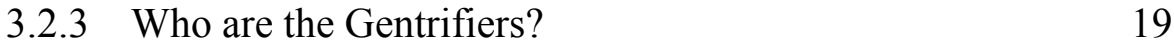

3.2.4 Types of Development within Gentrification 20

4.0 METHODOLOGY 22

4.1 Research Objectives 22

4.2 The Methodology 23

4.3 Methodological Choices 25

$\begin{array}{ll}\text { 4.3.1 Selection of Cities } & 25\end{array}$

4.3.2 Selection of Snapshot Year 25

4.3.3 Condominiums Adjacent to Still-Operational Churches 26

4.4 Methodological Challenges 26

4.4.1 Identifying Gentrification Trends 26

$\begin{array}{ll}\text { 4.4.2 Census Data Challenges } & 29\end{array}$

$\begin{array}{ll}4.5 & \text { Applying the Methodology } \\ & 30\end{array}$

5.0 RESEARCH FINDINGS 31

$\begin{array}{lll}5.1 & \text { The Inventory } & 31\end{array}$

5.2 Neighbourhood Trends 33

5.2.1 Post-2011 Gentrification Trends 34

5.3 Analysis of the Findings 38

5.4 Implications of this Research 38

$\begin{array}{ll}5.5 \text { Summary of the Findings } & 40\end{array}$

6.0 BUILDING ON THIS RESEARCH

6.1 A Future of Gentrification 42

6.2 Reflections for Professionals 43

6.3 Reflections for Academics $\quad 46$

6.4 Moving Forward 48 


\section{LIST OF TABLES}

Table 1: Post-Institutional Condominium Conversions by City and Type

Table 2: Post-Institutional Condominium Conversions within Processes of Neighbourhood Change

\section{LIST OF FIGURES}

Figure 1: Map of Post-Institutional Condominium Conversions - Toronto 32

Figure 2: Map of Post-Institutional Condominium Conversions - Ottawa 32

Figure 3: Map of Post-Institutional Condominium Conversions - Hamilton

\section{LIST OF APPENDICES}

Appendix A: List of Post-Institutional Condominium Conversions 


\section{CHAPTER 1: INTRODUCTION}

Conversions of non-residential or old rental apartments to condominiums and lofts are the least prevalent of the three forms of gentrification... they would appear to be stimulated mainly by investment in other forms, and thus a reactive process rather than the driver of gentrification in Canadian cities. This is not to say, however, that conversions are uncommon or unimportant... in some places [they] would appear to have significantly contributed to the full gentrification of the local neighbourhood. (Walks \& Maaranen 2008, 49)

This commentary comes from R. Alan Walks and Richard Maaranen's 2008 report on the timing and patterning of gentrification in major Canadian cities. In this study, they address the role of three types of housing stock that factor into modern gentrification processes: standard renovations or restorations, new builds, and the third type mentioned above, conversions of either former rentals or former non-residential buildings to market condominiums.

Walks and Maaranen's analysis of this third type attempts to aggregate all kinds of non-residential conversions, but it becomes clear throughout the chapter that they are primarily envisioning a post-industrial loft typology. They note, for example, that "[c]onversions... occur mostly in areas with some older industrial fabric bordering districts containing standard forms of renovation" (49). Industrial lofts may be the most common type of residential loft conversion, however they are not the only ones that may influence neighbourhood gentrification processes.

The adaptive reuse of schools and churches is rapidly emerging as a common alternative to the post-industrial loft conversion. Nicholas Lynch (2013) refers to these projects as post-institutional loft conversions. Throughout North America, school and church lofts have been recognized as a growing trend (Lynch, 2013; Caulfield, 2015; Wiebe \& Quinn, 2010). Unlike post-industrial lofts that are largely constrained to former industrial districts or infrequently to the edges of residential neighbourhoods, school and church lofts are generally located deep within low-rise, inner-city residential 
communities (Phipps, 2008; Hutton, 2014). They are intrinsically tied to these communities, formerly providing meeting places, recreational facilities, and various kinds of social support (Button, 2009; Sauve, 2014). Because these community institutions are so deeply embedded in the physical and social structures of their neighbourhoods, it is likely that their adaptive reuse as exclusive private condominiums may influence neighbourhood gentrification in a unique way.

There is currently very little research as to the role of post-institutional residential condominiums in neighbourhood gentrification processes. While Walks and Maaranen (2008) have found that condominium conversions in general tend to be reactors as opposed to drivers of gentrification processes, this paper will examine the role of postinstitutional condominium conversions in the gentrification of their neighbourhoods. It will build on the existing literature in order to expand the currently limited understanding of their role, seeking to determine exactly how these conversions influence processes of neighbourhood change.

\subsection{Research Question}

This research explores the role of post-institutional lofts in gentrification processes by attempting to locate such conversions within the gentrification periods of their respective neighbourhoods. The study features an examination of 40 postinstitutional loft conversions in Toronto, Ottawa and Hamilton, currently the three largest pre-war municipalities in Ontario. The research objective is to understand whether such conversions have potential to play a driving role in neighbourhood gentrification processes, effectively shifting from a community service role to a force for displacement and exclusion. While post-institutional conversions are already understood within the very limited scholarship as factors in gentrification processes, we are as of yet unclear as to the role they play.

This is an important question because much of the literature around adaptive reuse considers it to be a positive strategy in heritage conservation, environmental sustainability, and economic marketability (Shipley, Utz \& Parsons, 2006; Langston, Wong, Hui \& Shen, 2007; Shipley \& Kovacs, 2007; Archer, 2009; Bullen \& Love, 
2011a; Hutton, 2014). The scholarly field on adaptive reuse is still small, however there are very few pieces that attempt to examine it critically before recommending avenues for its pursuit. This paper will provide scholars, policymakers and adaptive reuse champions with a better understanding of the potential consequences involved with creative adaptive reuse projects. This exploratory research is intended as an academic contribution to an existing but very limited scholarship around the intersection of adaptive reuse and gentrification.

\subsection{Overview of this Paper}

Chapter 2 begins this paper with an exploration of the context for the research. It examines the $21^{\text {st }}$ century realities of inner-city living and widespread gentrification, growing trends in adaptive reuse, and the intersection of the two.

Chapter 3 reviews the literature around gentrification, adaptive reuse, loft conversions, post-institutional loft conversions, and then the very limited and specific work on post-institutional loft conversions within gentrification processes.

In Chapter 4, the paper details the methodology used to evaluate the role of loft conversions within gentrification processes, which involves a discussion of the postinstitutional loft inventory development as well as the methods used to discern gentrification processes in each of the 40 corresponding neighbourhoods.

Chapter 5 explores the research findings, and reflects on potential challenges and implications within the research. Finally, Chapter 6 concludes the paper with preliminary reflections for professionals, as well as several further research directions for those interested in exploring the intersection of adaptive reuse and neighbourhood gentrification in inner cities in Ontario. 


\section{CHAPTER 2: CONTEXT}

\subsection{Adaptive Reuse}

Adaptive reuse is the process by which older, underused buildings are upgraded and creatively converted to serve new uses (Young, 2009). It is a strategy that is rapidly gaining in popularity, especially given the rise of post-industrial cities where entire districts have ultimately fallen into disuse. The adaptive reuse of buildings in these districts as offices, co-working spaces and residential lofts, such as in Toronto's Liberty Village, provides an opportunity to reintegrate formerly obsolete buildings into the modern function of the city.

Adaptive reuse projects are increasingly undertaken for buildings that have outlived their usefulness in institutional and commercial sectors as well (Lynch, 2013). In the planning field, adaptive reuse is now positioned as a positive alternative to demolition, which is reflected in provincial and municipal planning policy throughout Ontario. Ontario's 2014 Provincial Policy Statement notes the following in Section 1.6.3.b: "Before consideration is given to developing new infrastructure and public service facilities, opportunities for adaptive reuse should be considered, wherever feasible" (16). While this is constrained to adaptive reuse projects for public uses, a policy that is also reflected in various municipal plans, Ontario municipalities additionally encourage heritage conservation through adaptive reuse within the private sector.

The City of Toronto Official Plan notes in Section 3.1.5.8 that "[ $\mathrm{t}]$ he adaptive reuse of properties on the Heritage Register is encouraged for new uses permitted in the applicable Official Plan land use designation" (2015, 3-13). The Urban Hamilton Official Plan notes in 3.1.11 that "[a]rts and culture... can play a significant role in the adaptive reuse of older buildings and the transformation of deteriorated neighbourhoods and commercial areas (2009, B-4). Section 3.4.3.8 also notes that "[t]he City shall encourage the intensification and adaptive reuse of commercial and industrial heritage properties. All permitted redevelopment shall ensure, where possible, that the original building fabric and architectural features are retained" (2009, B-28). In Ottawa, the Official Plan 
interestingly looks to adaptive reuse, among other strategies, to promote the development of affordable housing (2003, 2-52).

There is interest in adaptive reuse as a strategy to conserve heritage assets, to meet existing needs, and frequently, to maintain a local sense of a shared past (Hutton, 2014). There are widespread examples throughout the world of adaptive reuse projects that provide for public or semi-public access to reused buildings, for example in Paris at the Musée d'Orsay, formerly a major rail hub (Musée d'Orsay, 2006), or in Helsingor, Denmark, where the former dry dock squares have recently been creatively adapted as the Danish National Maritime Museum (Glancey, 2014). London's Tate Modern gallery, converted from a post-industrial factory, has explicitly taken steps to reach out to its community and represent a sense of shared history (Dean, Donnellan \& Pratt, 2010).

In Ontario, there are examples throughout the province of buildings adapted to public or semi-public functions. Oakville's Queen Elizabeth Park High School has been converted as a community centre (Sooley, 2012), as has Old Ottawa South's local fire hall (CBC News, 2010). Also in Ottawa, the All Saints Anglican Church is currently being redeveloped as a multi-faith worship and event centre featuring communityoriented businesses like a café, as well as a heritage interpretation exhibit (Spears, 2015).

In Toronto, public and semi-public institutions are engaged in large-scale adaptive reuse projects. Some notable examples include the conversion of the former Don Jail as the administrative centre at the Bridgepoint Health rehabilitation hospital (Macdonald, 2013), or the Toronto Police Services' conversion of a former gas purification plant as the 51 Division station. Toronto has also seen multiple examples of office or industrial conversions as non-profit hubs, with two examples being the 401 Richmond arts hub and the former Robertson office building as the Centre for Social Innovation (Wilson, 2010).

But despite an apparent interest in facilitating public accessibility to these built heritage assets, they provide real opportunities for commodification and profit. In a study conducted on the financial viability of adaptive reuse, Shipley, Utz and Parsons (2006) found that although conversions may require more upfront capital from developers than new builds, they tend to yield a much higher return on investment. This is usually due to their marketability as upscale businesses or residential addresses. Lynch similarly conducted analyses of marketing materials for church loft conversions, and found that 
these projects were almost universally advertised as "desirable upscale homes" (23, 2013). The heritage assets scattered throughout the built environments of major cities are less likely to be maintained as accessible places to tell shared stories, but instead are often adapted to private highest and best uses.

\subsection{Intersecting Heritage and Gentrification}

Built heritage conservation has been entwined with gentrification processes since their initial identification in the mid-1960s. Gentrification is the process by which disinvested, working class neighbourhoods are progressively resettled and upgraded by urban middle classes, to the point of displacement of the neighbourhood's initial residents (Glass, 1964; Smith, 1979). While understandings of gentrification have shifted over the last half century, Walks and Maaranen (2008) have identified three elements of the definition that have consistently endured: a) a discernable shift in the housing tenure in the neighbourhood; b) rising land values and declining housing affordability, and; c) a shift in the class composition of neighbourhood residents from working class to middle class or higher.

Gentrification was first observed as an emerging trend with the advent of the postindustrial city, which saw changes in urban function and land use across major cities in advanced capitalist states. Functional factory and warehouse buildings became obsolete en masse in the three decades following the Second World War, as industrial jobs were exported to regions with more competitive labour costs, and governments began to redirect investment toward the tertiary and quaternary sectors. Meanwhile, residents of pre-war working class neighbourhoods in inner cities were becoming underrepresented in an increasingly educated urban workforce (Lynch, 2013).

Post-industrial shifts in the economy were paralleled by social change in the 1960s and 1970s. Advanced capitalist states saw demographic changes like a decrease in household sizes, couples having fewer children and taking longer to have children, and an increase in women in the workforce. These shifts drove a decreased interest in the nuclear-family-oriented suburban households of the 1950s, with growing desire to live closer to workplaces, commerce and recreation in the city's downtown core (Bunting \& 
Phipps, 1988). Increasing suburban home values (Bunting \& Phipps, 1988) and decreasing property values in aging, disinvested urban neighbourhoods (Smith, 1979) combined with these factors to provoke interest in downtown neighbourhoods from a risk-taking, pioneer segment of the middle class (Lees, Slater \& Wyly, 2008).

The downtown neighbourhoods of early gentrification processes overwhelmingly exhibited heritage value. They were frequently over seventy-five years old, featuring Victorian-era architecture. The pioneer gentrifiers who purchased affordable homes in these neighbourhoods invested their own sweat equity in much-needed repairs and restorations (Clay, 1979). These artists and other young, risk-tolerant pioneers were additionally interested in the abandoned factories and warehouses of the industrial age, and they similarly restored these buildings to create basic, open-concept lofts (Zukin, 1982). In this way, the early gentrifiers also served as pioneers of the first modern trends in small-scale heritage restoration and adaptive reuse.

Heritage conservation as a movement emerged alongside the advent of gentrification processes in post-industrial cities, coming directly as a response to the urban renewal strategies and proposed megaprojects of the mid-century modernist planning age (Lees, Slater \& Wyly, 2008). Conservation advocates banded together against the mass neighbourhood demolitions proposed for megaprojects such as Toronto's ill-fated Spadina Expressway. Over time, these predominantly middle-class groups began to see their values reflected in political decisions, such as the refurbishment of Toronto's historic St. Lawrence Hall in celebration of Canada's centennial (Sewell, 1993). It is possible to identify an ensuing trend in adaptive reuse, as more risk-averse middle class consumers followed the pioneers to the post-industrial lofts and heritage districts they had popularized (Zukin, 1982). Prior research conducted by the author reveals such trends in adaptive reuse in Toronto, emerging in full force in the 1970s and 1980s (Abramowicz, 2014).

A respect for built heritage assets yielded the realization that heritage could be commodified. In his reflections on gentrification in Toronto, Caulfield has written that "[m]any of the handful of old office buildings still remaining in Toronto have been refurbished as prestige addresses. Fashions shift. Today, history sells" $(1994,20)$. Between their central locations and architectural appeal, the inherent value of pre-war 
inner-core properties has been recognized and exploited by middle-class gentrifiers, to the detriment of the working-class residents who have lived in these neighbourhoods in the decades since the original, wealthier residents migrated elsewhere. These working class residents are eventually displaced, encouraged to leave for more hospitable terrain either by dramatic measures such as landlord harassment or eviction, an inability to afford rents, or less direct consequences such as a decrease in affordable local commerce or relevant community services (Lees, Slater \& Wyly, 2008). They are generally forced to relocate to less valuable land further from the core, where they are positioned further away from the employment, public transit and services they need (Walks \& Maaranen, 2008).

\subsection{Corporatizing Gentrification in the $21^{\text {st }}$ Century}

Gentrification has shifted in several observable ways since the mid-1990s, one of which being that real estate developers are increasingly playing a central and driving role in the process. Initial stage theories of gentrification placed developers only in the final stages of neighbourhood change, entering the local market once pioneer and then more risk-averse gentrifiers had effectively minimized the risk involved with future investment there. Developers were previously much less likely to purchase land in such neighbourhoods prior to their widespread demographic change, as these would make for much riskier ventures with uncertain returns on investment.

Real estate developer roles in gentrification processes have changed since the 1990s for a number of reasons. The first is that the public sector is increasingly working as a facilitator for investment and economic development throughout the city. Municipal policies in the neoliberal era have shifted to encourage and support developers in their inner city investments, which has helped to mitigate risk for these developers.

The second is that gentrification is now recognized as a near universal force across post-industrial cities, which has served to truncate the formerly distinct stages of the gentrification process. Because it is understood that early-stage neighbourhoods are imminently likely to gentrify, developers are able to enter the process earlier and with more certainty (Hackworth, 2002). Early stage theories of gentrification only saw the 
entrance of developers near the end of the process, after the arrival and initial work of the pioneer gentrifiers and the subsequent decline in risk following the influx of young, middle-class professionals (Lees, Slater \& Wyly, 2008), however the truncated process facilitates the developers' arrival much earlier (Hackworth, 2002). Finally, since the 1990s, local economies have developed unprecedented linkages with economic networks in global cities around the world; developers have reflected this trend, growing larger and less local, which has increased their ability and capital to invest in neighbourhoods in order to spark and drive gentrification processes (Hackworth, 2002).

Another shift observed since the 1980s and 1990s has been the relevance of not only standard home-restoration drivers of gentrification, but also that of new build development (Lees, Slater \& Wyly, 2008). While Walks and Maaranen (2008) argue that new builds have in fact played a role in gentrification processes since the 1960s and 1970s, their more recent recognition may be reflective of their emerging significance within the process. Locally, the $21^{\text {st }}$ century has seen a dramatic increase in condominium living throughout the inner cores of large Canadian municipalities. Cities such as Toronto have experienced large-scale population growth, and intensification has manifested as a mass increase in private residential condominium buildings. This trend is no longer constrained, as it once was, to several small blocks within the downtown cores of major cities, but can be additionally identified in smaller and suburban municipalities throughout Canada and beyond (Lehrer \& Wieditz, 2009).

Gentrification has begun to incorporate real estate developers as major drivers within its increasingly universalizing process. This is reflected not only in the advent of new-build-led gentrification, but also in the corporatization of residential loft conversions. The artists who initialized colonized these abandoned buildings popularized the concept so effectively as to attract middle-class consumers, along with the developers who would adapt these properties from bare, open-concept spaces to multiple smaller, boutique units, effectively maximizing the profit to be gained from every square foot. Today, most artists can no longer afford an apartment within the vast majority of postindustrial loft conversions (Lynch, 2013).

Post-institutional loft conversions are similarly developer-driven in the $21^{\text {st }}$ century, but unlike post-industrial lofts, school and church condominiums have no history 
of initial conversions by early-stage gentrifiers. This is partially because there has been no historical abandonment of their original functions akin to post-war deindustrialization processes, but also partially because schools and churches are significantly more challenging to adapt to residential uses. Unlike open and rectangular former warehouses, schools and churches exhibit structural complexities in their staircases, diverse room sizes, and various other elements. They are also sometimes subject to heritage designations, which can require the use of particular construction materials or techniques throughout their redevelopment. Developers are much more likely than pioneer gentrifiers to have the skills and capacity to undertake such work (Lynch, 2013).

Recent post-institutional loft conversions in Ontario have been initiated by established developers such as Daniels Homes and Stinson Properties, and their adaptations designed by high-profile firms such as Diamond Schmitt and Quadrangle Architects (Hackworth and Gullikson, 2013; O’Reilly, 2012; Bentley Mays, 2014; Quadrangle Architects, 2016). Ontario's post-institutional loft conversions are evidently driven by corporate agents, and have been recognized as factors within neighbourhood gentrification processes.

This chapter has set the stage for further investigation into the specific role of post-institutional condominium conversions in neighbourhood gentrification processes. The next chapter explores the existing literature on adaptive reuse and gentrification before delving into the findings of this study. 


\section{CHAPTER 3: LITERATURE REVIEW}

The intent of this research is to examine one facet of the intersection between heritage conservation and gentrification. This literature review will thus explore current perspectives on both gentrification and adaptive reuse. There has been significantly more scholarly work done on the subject of gentrification, but there does exist a small and somewhat diverse field of scholarship on adaptive reuse practices.

Chapter 3 identifies leading scholars and their conflicting opinions as well as any gaps in the body of gentrification and adaptive reuse literature, with particular focus on post-institutional conversions, adaptive reuse as it intersects with gentrification processes, and gentrification theories over the last half century.

Lynch has noted that there is minimal academic consideration of post-institutional adaptive reuse projects, and that these are largely addressed in the media, if at all (2009). In fact, there exists a subset of scholarly literature on post-institutional adaptive reuse, but the vast majority has not been formally published. Throughout this body of research and media coverage, there has been very little attention directed to the intersection between such projects and gentrification processes. Lynch has reflected that this lack of research hinders scholars' ability to study "the impacts of such conversions on the real estate market or their local neighbourhood[s]" $(2009,142)$. His work on condominium conversions of former churches works to address this research gap and constitutes a significant contribution to the field; it will be addressed over the course of this literature review.

\subsection{Literature on Adaptive Reuse}

There are very few scholars, locally and internationally, who have chosen to focus their research on the study of adaptive reuse. In a notable example of such research, Australian scholars Peter Bullen and Peter Love regularly conduct research on the benefits of adaptive reuse projects and the challenges that impede them. They have produced studies on factors that influence the successful adaptive reuse of a building (2011b) and perspectives on adaptive reuse as a development strategy (2010), and they 
have conducted additional work such as the development of a decision-making model for choosing whether or not to undertake an adaptive reuse project (2011c).

In Canadian scholarship, the University of Waterloo's Robert Shipley has led several studies on adaptive reuse through the School's affiliated Heritage Resource Centre. Much of this research is geared toward encouraging developer-led adaptive reuse projects. In a 2006 example, he studied developer perspectives on their adaptive reuse projects, concluding that such developments on average tend to yield higher returns on investment than new builds (Shipley, Utz \& Parsons). He has supervised further work comparing adaptive reuse conversion pro formas to hypothetical demolition-and-rebuilds and greenfield new builds for similar uses (Stas, 2007). Other pieces are geared toward encouraging adaptive reuse less from a feasibility perspective but instead from an environmental one, arguing that such projects conserve the "embodied energy" it has taken to create buildings that already exist (Shipley \& Kovacs, 2007).

The majority of local adaptive reuse scholarship has been unpublished, emerging from graduate-level research at planning schools across Canada. Master's research papers in recent years include Chook's study of office-building adaptive reuse toward residential uses in Kingston (2011), Zuk's study of adaptive reuse microbreweries in Toronto (2015), and ongoing research by Zandvliet concerning the adaptive reuse of former hospital sites in Ontario (S. Zandvliet, personal communication, March 15, 2016).

There has been a prominent focus among planning students on the conversion of former churches and schools. Button's 2009 Ottawa-based research concerns the involvement of communities in school conversion processes, while Sooley's 2012 research examines three case studies to determine opportunities and constraints around the adaptive reuse of former school sites in Ontario. In 2014, Hutton's research in Hamilton addressed the features of schools that influence conduciveness to residential conversion, while Sauve, like Button, studied the public's involvement in the future of Ontario's surplus school sites. Meanwhile, Amayu (2014) paralleled Sooley's research through his Kingston-based study of opportunities and barriers to the adaptive reuse of former churches.

This existing research tends to address particular sociological issues, with some school conversion studies focusing on the impact in communities from the loss of a 
school site (Button, 2009; Clandfield, 2010; Sauve, 2014) and church conversion research touching on a growing secularization in society (Ley \& Martin, 1993; Hackworth \& Gullikson, 2013; Lynch, 2013). The literature varies on its approach to the potential negative consequences of such trends and others that are frequently identified alongside conversion processes.

\subsubsection{Divergent Perspectives on Adaptive Reuse}

The most significant conflict within adaptive reuse scholarship is the divergence on its status as a positive strategy in the conservation of built heritage resources. There are those who explicitly advocate for adaptive reuse and whose research is directed toward broadening its popularity, there are those who recognize it as a useful strategy in the face of difficult circumstances but recommend its use with conditions, and at the end of the spectrum, there are academic contributions on the ways adaptive reuse projects frequently yield problematic socioeconomic effects in their local communities.

The published scholarship on adaptive reuse seems to be almost entirely in favour of such ventures, with Shipley, Bullen and Love explicitly working to encourage developers to pursue conversion as a method of heritage conservation and environmental sustainability (Shipley, Utz \& Parsons, 2006; Shipley \& Kovacs, 2007; Bullen \& Love 2010, 2011a, 2011b, 2011c). The environmental argument considers not only the "embodied energy" originally used in constructing the building, but further energy and materials that would be used in the demolition and construction of a new one (Bullen \& Love, 2010).

Heritage professionals are similarly in favour: Archer has noted that adaptive reuse is the ideal response to an increasing number of Toronto-area school closures, even if school boards seem to disagree (2009). Her piece entirely disregards the potential for future neighbourhood demographic change that would once again create a need for local schools, the sites for which might be leased or used by school boards until they are needed again. In their piece on the future of Canada's heritage schools, Wiebe and Quinn similarly encourage the redevelopment of abandoned schools as "private schools, 
community centres and condo developments" $(2010,21)$, again with minimal regard for the permanent loss of such sites.

Sooley (2012) and Amayu (2014) demonstrate explicit support for conversion projects in their studies on the opportunities and constraints involved with the adaptive reuse of schools and churches respectively. They both present the perspective that adaptive reuse is a successful strategy toward the conservation of buildings with social and cultural significance in their local communities, and their research is geared toward the minimization of potential policy barriers to the process.

The research conducted by graduate students Button (2009) and Sauve (2014) takes a more measured perspective toward the adaptive reuse of former school sites, acknowledging that it serves as a solution to the endemic problem of surplus schools, but recommending specific adjustments to the process that aim to mitigate any negative impacts of adaptive reuse conversions. Button looks to improve community participation in determining the future for former local schools, and to recommend strategies for the preservation of schoolyard green space even while the former school buildings are redeveloped (2009). Sauve recommends the increased involvement of municipal planning departments in school board negotiations and surplus-school decisions in order to facilitate more effective public involvement in the future of such school sites (2014). In a study on efficient future uses for surplus school sites, Phipps recommends adaptive reuse as a strategy only where it will assist future owners in achieving the site's highest and best use. He has developed an urban-economic development rule that will allow school boards and buyers to effectively assess the sites in question to determine their most efficient future uses (2008).

A small group of researchers are engaged in studies on the negative consequences of adaptive reuse projects, largely exploring the role of adaptive reuse ventures within larger gentrification processes. Hutton alludes to gentrification concerns in her evaluation of school sites conducive to residential conversion, noting that such adaptive reuse projects have the power to indirectly influence surrounding property values, and that their appeal to more affluent tenants assists in changing the demographic character of the neighbourhood (2014). Young's 2009 study of the City of Los Angeles's 'Adaptive Reuse Ordinance' features a more central focus on the relationship between adaptive 
reuse and gentrification, identifying downtown displacement as a direct consequence of this municipal policy. Young has noted that although the policy was developed to incentivize the creation of more housing stock, it has largely been used to convert existing housing stock to less affordable residential uses, effectively displacing those who had been living in the buildings at affordable rents.

Finally, Lynch's 2013 thesis presents a comprehensive study of post-institutional adaptive reuse projects, specifically church conversions into condominiums, for the benefit of the gentrifying "new middle class". His research examines church condominiums as indicators of changing attitudes toward religion within contemporary urban gentrification processes. He uses a mixed methodological approach to analyse this shift, first tracking self-reported census data on religious belief in communities that are gentrifying or have gentrified, then conducting interviews with diverse actors throughout church-to-condominium conversion processes, and finally running textual analyses of marketing materials for these condominiums, reflecting on the socioeconomic groups to whom they are advertised (2013). Lynch's research identifies post-institutional condominium conversions as agents within gentrification processes, but as noted, he hesitates to reflect on their specific role within the gentrification of their respective neighbourhoods. This research attempts to address the gap he identifies, following a necessarily brief review of the existing scholarly field on gentrification.

\subsection{A Brief Overview of Gentrification Literature}

This research is based in an understanding of gentrification that has been evolving since its initial identification in 1964. It will be important to review the many conflicts within our modern conceptualization of gentrification processes in order to develop a reference point for the assumptions involved with this research. It should be noted, in particular, that this research incorporates several post-1990s perspectives on gentrification that present significant departures from the classic definitions of the late 1970s and early 1980s; these will be noted in the following sections where relevant. The remainder of this literature review will address the conflict between production and 
consumption explanations of gentrification, Canadian perspectives, definitions of the prototypical "gentrifier", and types of development within the process.

This will serve as a very brief overview of the literature on gentrification. It will not address several of the conflicts within the body of scholarship, and will only graze the surface of those that are mentioned here. For more detail on the vast body of literature concerning gentrification and its intersection with heritage, condominium projects and other themes of this research, one should look to Chapter 4 of Lynch's thesis (2013), which presents an excellent and comprehensive review of gentrification literature as it applies to his very similar research topic.

\subsubsection{Production and Consumption Explanations of Gentrification}

Gentrification scholars have historically subscribed to either the production or consumption explanations behind neighbourhood gentrification. The production-based explanation, proposed by Scottish geographer Neil Smith, views gentrification as the outcome of natural cycles of capital throughout the city over time. The consumptionbased explanation, championed by geographer David Ley and others, recognizes gentrification as a marker of changing preferences as middle-class Baby Boomers have come of age. The two explanations represent a central conflict throughout the literature on gentrification (Lees, Slater \& Wyly, 2008).

The production-side explanations have understood gentrification processes to be the natural outcome of neighbourhoods that have seen disinvestment and decline since their initial construction. The trend was first identified as cities in advanced capitalist states began to transition to the post-industrial era. In these cities, Victorian-era neighbourhoods in the inner core had been experiencing depreciation since their initial cycles of use around the turn of the century, and the post-war period saw an exodus of middle-class residents to the newly-built suburbs ${ }^{1}$. In the inner-city neighbourhoods, landlords continued to undermaintain their properties, and charged increasingly lower

\footnotetext{
${ }^{1}$ In American cities, this trend manifested as "white flight to the suburbs", with working class African Americans remaining in the inner cities. In Canada, the exodus was not notably segregated by race; some white middle-class residents left for the suburbs while others, along with white working-class residents, remained in the downtown core (Dantas, 1988).
} 
rents to reflect the quality of living conditions on site. By the 1960s and 1970s, however, suburban costs of living had seen significant growth, between increasingly expensive newly-built homes that were further away from employment opportunities in the core, and commuting costs that had risen drastically with the 1970s oil crises.

At this stage, cities reached a tipping point in urban economics, where it became more affordable to purchase and upgrade a depreciated inner-city property than to buy in the suburbs. Drawn to such neighbourhoods by risk-tolerant pioneer gentrifiers, young middle-class investors quickly realized that the large gap between capitalized and potential ground rents could be exploited to purchase properties cheaply and upgrade them, eventually profiting from newly attractive properties on valuable inner-city land. As such, investments began to shift from suburban neighbourhoods back to the inner city, injecting older neighbourhoods with the capital necessary to become attractive and exclusive to middle- and upper-class buyers (Smith, 1979). Production-side scholars argue that gentrification trends continue today as rent gaps are sought and found in depreciated older neighbourhoods with architectural potential as well as advantageous proximity to transit lines or to the inner core itself (Hackworth, 2002).

The literature that approaches gentrification from consumption-based perspectives presents a different case, arguing that gentrification has emerged from distinct societal changes that have provoked new lifestyle preferences. The rise of the post-industrial city was characterized by a shift in urban policy and planning; the interests of the workers who had inhabited the inner city were supplanted by those of a "new middle class", whose rising disposable incomes drove a new conception of the city as a place for recreation and consumption rather than for work (Lynch, 2013). The suburban nuclear families of the 1950s had been succeeded by a generation characterized by higher divorce rates, later marriages, fewer children, and female as well as male income earners. These were lifestyles that were less conducive to living in suburban, single-detached homes far from urban employment and amenities (Smith, 1979; Rose, 2010). Because of this, young, middle-class professionals returned to the inner cores of cities, and the market responded to their preferences around cultural amenities, restaurants, shopping and cafes, and notably, aesthetically interesting architectural heritage (Lynch, 2013). 
As the former, structuralist argument fails to acknowledge undeniable sociological shifts, and as the latter, consumption-based argument neglects the reality of profit-driven investors in depreciated neighbourhoods, most gentrification scholars today recognize the interplay of these two perspectives. They are both understood to factor into the gentrification processes of the 1960s and 1970s as well as those that continue to occur today (Lees, Slater \& Wyly, 2008).

\subsubsection{Gentrification in a Local Context}

A prominent contingent of the researchers engaged in gentrification scholarship base their research in Canadian contexts. David Ley, who leads the field in consumptionbased sociological explanations of gentrification, works out of the University of British Columbia, alongside Elvin Wyly, Nicholas Lynch, and occasionally Loretta Lees. Walks and Maaranen are based out of the University of Toronto, as is Jason Hackworth; their research has informed much of this paper's understanding of the post-1990s iteration of gentrification processes. Tom Slater, the third editor alongside Lees and Wyly of their comprehensive gentrification reader, has conducted extensive fieldwork in Toronto. Damaris Rose, another significant voice in the consumption-based scholarship and specifically on women's roles in the process, operates out of the Centre Urbanisation Culture Société in Montreal. These researchers' reflections are necessarily informed by Canadian urban contexts, and it is thus possible to apply their learnings to this research without fear of deriving background context from potentially inapplicable studies of British and American cities.

The distinction is important because Canadian inner-city neighbourhoods have experienced markedly different gentrification patterns from their American counterparts; Canadian inner cores have never experienced the same levels of extreme poverty and depreciation, nor have urban-suburban distinctions fallen along racial lines (Dantas, 1988; Hackworth \& Gullikson, 2013). This has made for less dramatic gentrification processes, which have thus spread more easily through Canadian inner cities (Bunting \& Phipps, 1988). 
Canadian cities have also been subject to the post-1990s spread of gentrification trends to provincial cities, such as in Hamilton (Gee, 2015) and Kitchener-Waterloo (Cornell, 2016). This has been identified as a modern facet of gentrification, with Dutton (2004) arguing that the overspill results from global cities overburdened with gentrification at the core, which in this case would be Toronto. The overspill concept accounts for the staggered timing and uneven nature of gentrification in core cities as compared to that in peripheral cities, however Lees, Slater and Wyly have disagreed, noting that it is possible to perceive initial gentrification patterns in Dutton's peripheral cities while the core cities are still undergoing their gentrification (2008).

It is nevertheless possible to identify gentrification patterns in cities throughout Ontario and the rest of Canada today. In 1988, Bunting and Phipps observed that smaller cities like Kitchener would see incumbent upgrading rather than full-blown gentrification. In Kitchener's case, they noted its lack of a significant white-collar middle class or the services and cultural amenities that would meet the needs of such a population. Today, demographics have shifted dramatically, driven by Kitchener's technology boom, and the city is undeniably experiencing gentrification in its recently disinvested downtown core (Waterloo Region Record, 2012; Cornell, 2016; Robertson Simmons Architects, 2016). The spread of gentrification to provincial cities such as Kitchener may be observed across the province; Hamilton's experience will be explored in further detail in Chapter 5.

\subsubsection{Who are the Gentrifiers?}

The classic definition of a gentrifying household is as follows: it consists of one to two members who are between the ages of 25 and 40, generally childless, with aboveaverage incomes and employed in professional occupations (Gale, 1979; Bunting \& Phipps, 1988; Kary, 1988; Dantas, 1988). This definition has long been understood to incorporate other specific groups as well, such as single parents or members of gay communities (Rose, 2010).

There is some conflict as to whether families may play a role in gentrification processes. Through research conducted in the Riverdale neighbourhood in Toronto's east 
end, Dantas found in 1988 that the new neighbourhood residents who were engaging in housing stock upgrades fit the profile of gentrifiers, with the notable exception that they had on average the same number of children as in other neighbourhoods across the municipality. Dantas concluded at the time that this necessitated an expansion of definitions of gentrification to include families willing to take on the risks of a depreciated neighbourhood.

In the decades since, however, families have apparently not been integrated into the commonly understood definition of the prototypical gentrifying household. In research as recent as 2014, Karsten has argued for the inclusion of families in this definition, demonstrating that there has been no universal acceptance of their inclusion in the 25 years between her research and Dantas's. Because the field does not yet accept families as gentrifiers on a universal basis, the research in this paper will operate under the current definition of small, young, adult-focused households in order to identify neighbourhood gentrification processes.

\subsubsection{Types of Development within Gentrification}

Gentrification processes have been traditionally recognized through identifiable shifts in the treatment of the neighbourhood's original housing stock. Older houses and buildings that have been subject to severe depreciation over a number of decades are purchased and restored to a high standard reminiscent of their original quality. In the process, households and businesses are progressively displaced from these locations, and middle- to upper-income households begin to dominate the demographic makeup of the neighbourhood. However, there is debate as to whether this constitutes the only form of development, or redevelopment, within gentrification (Walks \& Maaranen, 2008).

As noted in Chapter 2, Lees, Slater \& Wyly (2008) have argued that new-build gentrification, driven by developer-led condominium projects, emerged as a new typology in the 1980s, however Walks and Maaranen (2008) have maintained that new builds have played roles in the process since the 1960s. Regardless, it appears that their influence has grown in post-1990s gentrification, with both Smith and Defilippis (1999) 
and Hackworth (2002) identifying developers as central actors within the modern process.

Scholars debate the role of new builds within gentrification, because unlike standard home renovations and condominium conversions ${ }^{2}$, older, deteriorated buildings are not being restored to achieve potential ground rents and fulfill their highest and best uses. Davidson and Lees (2005) have shown, however, that new builds are in fact relevant within the process, in that they represent the reinvestment of capital in inner-city neighbourhoods, they draw prototypical gentrifiers, and they result in the displacement of former lower-income residents of the neighbourhood.

While new-build developments do not, of course, directly displace anyone in the same way as restorations and conversions displace the residents of those buildings, they function much in the same way as commercial agents of gentrification in that they indirectly displace original residents. They serve to raise nearby property values, and they attract a demographic in search of commerce and services to meet their desires and needs, effectively shifting the character of the neighbourhood until it no longer prioritizes the markedly different needs of the original working class residents (Davidson \& Lees, 2005). The research presented in this paper recognizes the significance of indirect displacement, which may be attributed not only to new-build developments but also to conversions of non-residential properties like churches and schools to residential condominiums.

This chapter has explored current perspectives on adaptive reuse and the future of former neighbourhood institutions, followed by a brief overview of the scholarship on gentrification spanning the last fifty years. Chapter 4 delves into the present research with a discussion of the methodology employed in this study.

\footnotetext{
${ }^{2}$ Condominium conversions are the third typology identified in Walks and Maaranen's research (2008).
} 


\section{CHAPTER 4: METHODOLOGY}

\subsection{Research Objectives}

This research is positioned to build on previous studies conducted on condominium conversions, and specifically post-institutional condominium conversions, within neighbourhood gentrification processes. Walks and Maaranen have suggested that condominium conversions tend to play a reactive role rather than a driving role in gentrification processes (2008), while Lynch has argued that post-institutional condominium conversions are markers of gentrification in that they are directly developed for a gentrifying "new urban middle class" (2013). The objective of this research is to expand this limited understanding of their role, determining whether they are in fact universal markers of gentrification, and if so, whether they emerge only after the process has been initiated by other forms of investment.

Community institution condominium conversions, or post-institutional condominium conversions, have been selected because they play a particularly unique role in the gentrification process. Unlike post-industrial condominiums, they tend to be located in the heart of residential communities, often on otherwise residential streets, but most importantly, they reflect a transition to neighbourhood exclusivity in their shift from community uses to private, up-market condominiums.

The methodology presented here has been designed specifically to identify trends in post-institutional condominium proposals as they fall within the span of gentrification processes. The research asks whether they largely fall later within these processes, which would confirm the hypothesis that such condominiums are proposed in neighbourhoods that have already seen sufficient change as to alleviate the developers' risk concerns. Conversely, if post-institutional conversions are more often proposed early within gentrification processes, they may instead be understood as drivers. The identification of trends like these might assist researchers, as well as players in this field, to better understand the impact of post-institutional condominium conversions in processes of neighbourhood change. 


\subsection{The Methodology}

The research takes a quantitative approach through the development of a 40-case inventory of post-institutional condominiums, comparing the inventory cases against census data on indicators for gentrification. It identifies how many have fallen within neighbourhood gentrification processes, and during what stage of the process they have fallen. The inventory was developed through a search of the current functions of all schools and places of worship that existed in Toronto, Ottawa and Hamilton, as well as their surrounding pre-amalgamation municipalities, in the year $1966^{3}$. The 1966 snapshot is derived from the annual directory for each municipality, which features "listings of businesses, churches, schools, social organizations [and] municipal services" (Hamilton Public Library, 2016). In order to develop a comprehensive snapshot for all three cities and their adjacent pre-amalgamation municipalities, a scan was conducted of the Toronto City Directory 1966 and the Ottawa City Directory November 1966, both of which cover their respective metropolitan regions, as well as the Vernon's Hamilton Directory 1966 and the Vernon's Hamilton Suburban Directory 1966: Ancaster, Burlington ${ }^{4}$, Dundas, Stoney Creek and Waterdown.

The snapshot listings were then used to locate current post-institutional condominiums through an identification of each listing's modern function. The snapshot was compared against current school lists from each city's public, Catholic, and French Catholic school boards, church listings for various religious dioceses, and where necessary, a search for the institution's address using online resources such as Google's search engine and map application, including its Streetview function in order to actually see physical development since 1966.

A variety of others sources were used in filling in gaps and confirming the inventory that eventually developed from this scan. The research was compared against

\footnotetext{
${ }^{3}$ In 1966, each of the three metropolitan regions included smaller, adjacent municipalities that would be amalgamated into the central city by the provincial government in 2001. In Toronto, this included the former municipalities of Etobicoke, Scarborough, North York, East York and York. In Ottawa, the list included Vanier, Nepean, Kanata, Gloucester and Cumberland, and in Hamilton, there was Ancaster, Stoney Creek, Flamborough, Dundas and Glanbrook.

${ }^{4}$ Burlington listings were eliminated from the snapshot, as Burlington has not been incorporated into the modern city of Hamilton, and instead operates today as a separate municipality.
} 
the Ontario Heritage Trust's Places of Worship Inventory, which maintains detailed records of all former and current places of worship in Ontario, as well as lists of Torontobased church condominiums developed through research by Hackworth and Gullikson (2013) and Lynch (2013). The research also benefitted from the author's existing knowledge of Ontario-based adaptive reuse projects, as well as that of select local residents in the Hamilton and Ottawa areas.

Following the development of the 40-case inventory, census data was collected in each condominium's neighbourhood in order to accurately place each case within a potential gentrification process. Each case's conversion application date was identified through the municipal legislative documents that were approved prior to construction; in most cases, these consisted of planning staff reports on the required Zoning By-law amendments or Official Plan amendments. In 16 cases, the author was unable to locate municipal documentation of the conversion application, so in those instances the project dates are confirmed using other sources ${ }^{5}$. The conversion application date was used where possible so as to determine at which point a developer would begin to consider a post-institutional condominium conversion within the neighbourhood, which speaks to the developer's attitude toward the neighbourhood's potential risk.

Neighbourhood data was then collected for each inventory case's Canadian census tract, using specified indicators for gentrification processes. Using Walks and Maaranen's 2008 research as a model, the census tract areas were used as proxies for locally understood neighbourhoods. Data collection spanned the 20 years prior to and following the conversion application date, providing the opportunity to look for gentrification trends over a 40 -year period.

The gentrification indicators used in this research consist of relatively basic criteria for gentrification processes, which was necessary due to the time and resource constraints of this project. Census data was collected for the following four indicators at both the tract and division level: average number of persons per household, percentage of the population within the 25-44 age range, percentage of the population with a university

\footnotetext{
5 In such cases where the project dates are confirmed using sources other than municipal documentation, the recorded date is usually a project completion date rather than an application date. It is sufficient for the purposes of this research to assume that those projects were proposed within the five years prior to completion.
} 
degree, and median household income. For each inventory case, the research looked to the tract level to identify a decline in average household size to the one- to two-person range, and then looked for a parallel rise in each of the other three indicators as compared with the division data, representative of the larger municipality. If a trend was determined, the conversion application date was used to determine where the inventory case had fallen within the process of neighbourhood change.

This method was used first to place each of the inventory cases either within or outside a neighbourhood gentrification process. The cases that occurred outside gentrification processes were categorized by a) those within neighbourhoods that were already wealthy and had been stable for at least 20 years prior to the conversion; b) those that occurred in years after full gentrification had apparently been achieved, and; c) those that occurred in a neighbourhood where a clear trend could not be identified. The cases that occurred within the neighbourhood's gentrification process were categorized by having been proposed early in the process, or once a gentrification process was already in clear progress. The results of this study are presented in Chapter 5.

\subsection{Methodological Choices}

\subsubsection{Selection of Cities}

The research has been constrained to the three largest pre-war municipalities in Ontario: Toronto, Ottawa and Hamilton. This has meant the exclusion of potential postinstitutional conversions that exist in Mississauga and Brampton, which are respectively Ontario's third and fourth largest municipalities (Statistics Canada, 2011). They were excluded because their development has largely occurred in a suburban, post-Second World War context, and as such their development patterns do not match those of municipalities most likely to exhibit large-scale gentrification trends.

\subsubsection{Selection of Snapshot Year}


The year 1966 was purposely selected to provide a snapshot of the community institutions that existed just prior to the advent of gentrification processes in Ontario. Toronto's Cabbagetown neighbourhood, which is recognized as one of the first gentrification processes in Canada, is understood to have begun gentrifying in the late 1960s and through the 1970s (Kary, 1988). 1966 was chosen so as to capture existing community institutions before they were likely to have been converted.

\subsubsection{Condominiums Adjacent to Still-Operational Churches}

A decision was made to include condominiums that have been converted from church lands where some section of the church remains still operational in the organization's hands. This includes the cases of the Channel Club (adjacent to the College Street United Church), the Hepbourne Lofts (adjacent to a Portuguese Presbyterian church), and the Glebe Lofts (adjacent to the Riverdale Presbyterian Church). These condominiums were included in the inventory because although they do not necessarily represent a transition to secularization, the focus of this research is on a shift from community institutions to more private, exclusive uses, and in these cases the section of property sold was formerly operational as the church's community space. The community services they once offered may have thus been supplanted in some way by the conversion as a private condominium.

\subsection{Methodological Challenges}

\subsubsection{Identifying Gentrification Trends}

The primary challenge faced in undertaking this research was the difficulty in comprehensively identifying a gentrification process. Lees, Slater and Wyly have previously identified the immense challenge in demonstrating the fulfillment of a rent gap, one of the central indicators of gentrification:

To measure the rent gap properly, a researcher has to construct specialized indicators after sifting through decades of land records and becoming familiar 
with the details of historical market conditions, neighbourhood settings, tax assessment practices, the provisions of government subsidies, and other factors. It's not surprising that very few researchers have invested the time and effort. (2008, The Rent Gap Debates, paragraph 11)

Despite this challenge, there are a number of ways in which researchers have aimed to locate or confirm gentrification processes over the last fifty years of such research. Smith, Duncan and Reid (1989) have used tax arrear data to demonstrate the fulfillment of a rent gap by identifying the shift from disinvestment to reinvestment in a neighbourhood; Smith did so again in 1996 for a number of neighbourhoods in Manhattan (Lees, Slater \& Wyly, 2008).

Kary (1988) aimed to confirm Cabbagetown's fulfillment of a rent gap by tracking its property sale prices in Cabbagetown compared to the greater municipality over the time the gentrification process was said to have occurred. He was able to record a shift from much lower sale prices to sales that surpassed the municipal average over a short period of time, confirming the shift to reinvestment.

In their research on secularization in urban settings, Ley and Martin measured the gentrification of two neighbourhoods in Vancouver using the indicators of quaternarysector occupations, rising median incomes, university education and average rents, British origins, and childless households (1993). Ley has used a similar method in his major analysis of gentrification in Canadian cities, where he conducted detailed statistical analysis based on a wide variety of indicators (1986).

Walks and Maaranen measured gentrification processes with a similar indicatorbased approach. They used six indicators, including average personal income as compared with the municipality, change in social status based on level of education, changing percentages of artists as pioneer gentrifiers in the population, de-conversion of rental housing to owner occupation, rising average monthly rents, and rising average property values (2008).

Hackworth's 2002 research takes an indicator-based approach as well, using changes in the population, number and percentage of professionals, median incomes, housing units, median home values and median rents to identify gentrification trends. 
The method employed in this research is modeled after the indicator-based approach taken by these researchers. Due to the time and capacity constraints of the research, it is necessarily less rigorous than many of their studies; it neglects, for example, to measure the change between each of the four indicators over 40 years for all 40 cases. Despite this, the research aims to incorporate these models' principles, by observing a potential demographic shift toward gentrifying populations in neighbourhoods over time.

The first indicator, household size, was used to determine whether household sizes were descending toward a one- to two-person target. For each neighbourhood, the numbers were examined to see if they were descending, and if so, whether they leveled out at a particular number. Data sets that descended and then stabilized at 2.4 or 2.5 members were not necessarily understood to be gentrifying, whereas ones that reached numbers like 1.9 or 2.1 displayed clearer gentrification trends.

The indicators on university education and median household income were examined in tandem with the municipal data for the same years taken from the census division records. Because median household incomes and populations with university education have risen in all three cities over the last fifty years, gentrification trends were identified not just by rising numbers, but by numbers that rose from below the municipal standards to meet and then surpass them.

Similarly, the percentage of the population within the 25-44 age range was measured as compared to the municipality ${ }^{6}$; the research observed this data for initial growth, occasional stabilization at percentages notably higher than the municipality, and then some decline to reflect a potential gentrification process taking hold. This final decline was not sought universally, but was recognized as a potential consequence of the arrival of different demographics, those who might be more risk averse, following the initial push toward gentrification.

For each case, the four indicators were studied together over the 40 years within which the conversion took place, looking to see if the intersection of the indicator trends

\footnotetext{
${ }^{6}$ In the literature, gentrifiers are identified as falling within the 25-40 age range. This study has elected to measure the 25-44 age range instead due to a lack of availability of five-year-increment census data for a number of the years measured.
} 
revealed what would appear to be a gentrification process. The intersection of the indicators was particularly important; for instance, if median income levels rose to surpass the municipal level in a given neighbourhood, but average household sizes remained stable at 3.5 people over the full course of this process, this intersection would not be understood to indicate a gentrification process. The research aimed to identify a rise in 25-44 year olds, median household income levels and university degrees alongside a decline in household sizes to one to two people. The method allowed for some flexibility in the start point for each indicator's trends as well as the pace at which they would progress, but it effectively sought four trends occurring on an overlapping basis. Using this method, it was additionally possible to identify a distinction between the early stages and the active, ongoing stages of gentrification processes, a distinction that factors into the analysis of the conversion's role as an agent of gentrification.

\subsubsection{Census Data Challenges}

There are unfortunate limitations to the census data used in this study that have in some instances limited its reliability. First, the research sought to study each condominium conversion within a 40 -year context, with 20 years on each side, in order to accurately perceive gentrification trends before, during or after the proposal for the conversion. For all conversions proposed after 1991, however, the census data covers less than 20 years following the conversion, as the most recent census data comes from 2011. This is the case for almost half the conversions in the inventory.

There are similar challenges in the census data that comes from before the year 1981, although these challenges affect comparatively less of the cases in the inventory. Prior to the 1980s, Canadian census data was only collected every 10 years, so there are gaps in the neighbourhood data where the 40-year period spans 1966 or 1976 . There were additional challenges in locating some of the comparison data for Toronto's full census division in 1971. Appendix B details the indicator data for each case, where the lack of census records in certain years may be more clearly understood.

Most importantly, it must be noted that all 2011 census data merits less serious consideration than that of other years, given the voluntary nature of Canada's 2011 
substitute for the long-form census. Hulchanski, Moodie, Walks and Bourne at the University of Toronto have highlighted the lack of reliability associated with 2011 census data, specifically in its use as a tool to determine income inequality and the affiliated social services needs. They note that upper-income populations are more likely to participate in voluntary state-driven engagement such as the National Household Survey, and that this is likely to have yielded unreliable data in 2011 (Hulchanski et al., 2013). While this study's 2011 data for age and household size is taken from the mandatory census that year, the datasets on percentage of university graduates and median household incomes must be recognized for their limited reliability. This presents serious challenges in analyzing the neighbourhood context around the 50 per cent of conversions that have been proposed following the last reliable census in 2006. The analysis of these emerging cases will prove to be a useful future research direction following the availability of the 2016 long-form census data in the coming years (Campion-Smith, 2016).

\subsection{Applying the Methodology}

This chapter has established a comprehensive methodological framework for the research conducted in this study. The following chapter will review the development of the post-institutional condominium inventory in practice, as well as the results of where these conversions have fallen within their respective neighbourhood gentrification processes. 


\section{CHAPTER 5: RESEARCH FINDINGS}

\subsection{The Inventory}

The development of the post-institutional condominium inventory for the cities of Hamilton, Ottawa and Toronto yielded a total of 40 condominium conversions. There were 25 identified in Toronto, seven in Ottawa, and eight in Hamilton. There are a total of 17 school conversions and 23 church conversions within the inventory ${ }^{7}$, with four school- and 21 church conversions in Toronto, seven school conversions in Ottawa, and six school- and two church conversions in Hamilton. The dates of these 40 conversion applications span an approximate 30-year period, from the late 1980s to 2015.

\begin{tabular}{|c|c|c|}
\hline \multicolumn{3}{|c|}{ TABLE 1: Post-Institutional Condominium Conversions by City and Typ } \\
\hline TORONTO & OTTAWA & HAMILTON \\
\hline \multicolumn{3}{|c|}{ SCHOOLS } \\
\hline Kensington Market Lofts & École Guigues & Waterdown District High School \\
\hline The Loretto & Schoolhouse Square & Allenby Lofts \\
\hline 36Hazelton & Archive Square & Dundas District Lofts \\
\hline \multirow[t]{4}{*}{ The Schoolhouse } & Les Lofts du Montfort & Stinson School Lofts \\
\hline & Le St-Denis & The Witton Lofts \\
\hline & École Sacré-Coeur & Gibson School Lofts \\
\hline & Yard and Station Lofts & \\
\hline \multicolumn{3}{|c|}{ CHURCHES } \\
\hline Macpherson Church Lofts & & St. Thomas Lofts \\
\hline The Channel Club & & The Connollly \\
\hline \multicolumn{3}{|l|}{ Woodlawn Church Loft } \\
\hline \multicolumn{3}{|l|}{ The Church Loft } \\
\hline \multirow{2}{*}{\multicolumn{3}{|c|}{$\begin{array}{l}\text { Hepbourne Lofts } \\
\text { Claremont Hall }\end{array}$}} \\
\hline & & \\
\hline \multicolumn{3}{|l|}{ St. George-on-Sheldrake } \\
\hline \multicolumn{3}{|l|}{70 High Park Avenue Condominiums } \\
\hline \multicolumn{3}{|l|}{ The Glebe Lofts } \\
\hline \multirow{2}{*}{\multicolumn{3}{|c|}{$\begin{array}{l}\text { The Abbey Lofts } \\
\text { West40 }\end{array}$}} \\
\hline & & \\
\hline \multicolumn{3}{|l|}{ The Church Lofts } \\
\hline \multicolumn{3}{|l|}{ The Swanwick Heritage Loft } \\
\hline \multirow{2}{*}{\multicolumn{3}{|c|}{$\begin{array}{l}\text { Victoria Lofts } \\
\text { College Street Baptist Church }\end{array}$}} \\
\hline & & \\
\hline \multicolumn{3}{|l|}{ Park Lofts } \\
\hline \multicolumn{3}{|l|}{ Bellefair Kew Beach Residences } \\
\hline \multicolumn{3}{|l|}{$\begin{array}{l}\text { St. Clement's Church Lofts Leslieville } \\
\end{array}$} \\
\hline \multirow{2}{*}{\multicolumn{3}{|c|}{ Sanctuary Lofts }} \\
\hline & & \\
\hline Blue Diamond & & \\
\hline
\end{tabular}

${ }^{7}$ It should be noted that all places of worship were included in the 1966 community institution snapshot for the three cities, however only churches seem to have been converted to condominiums as of Spring 2016. 


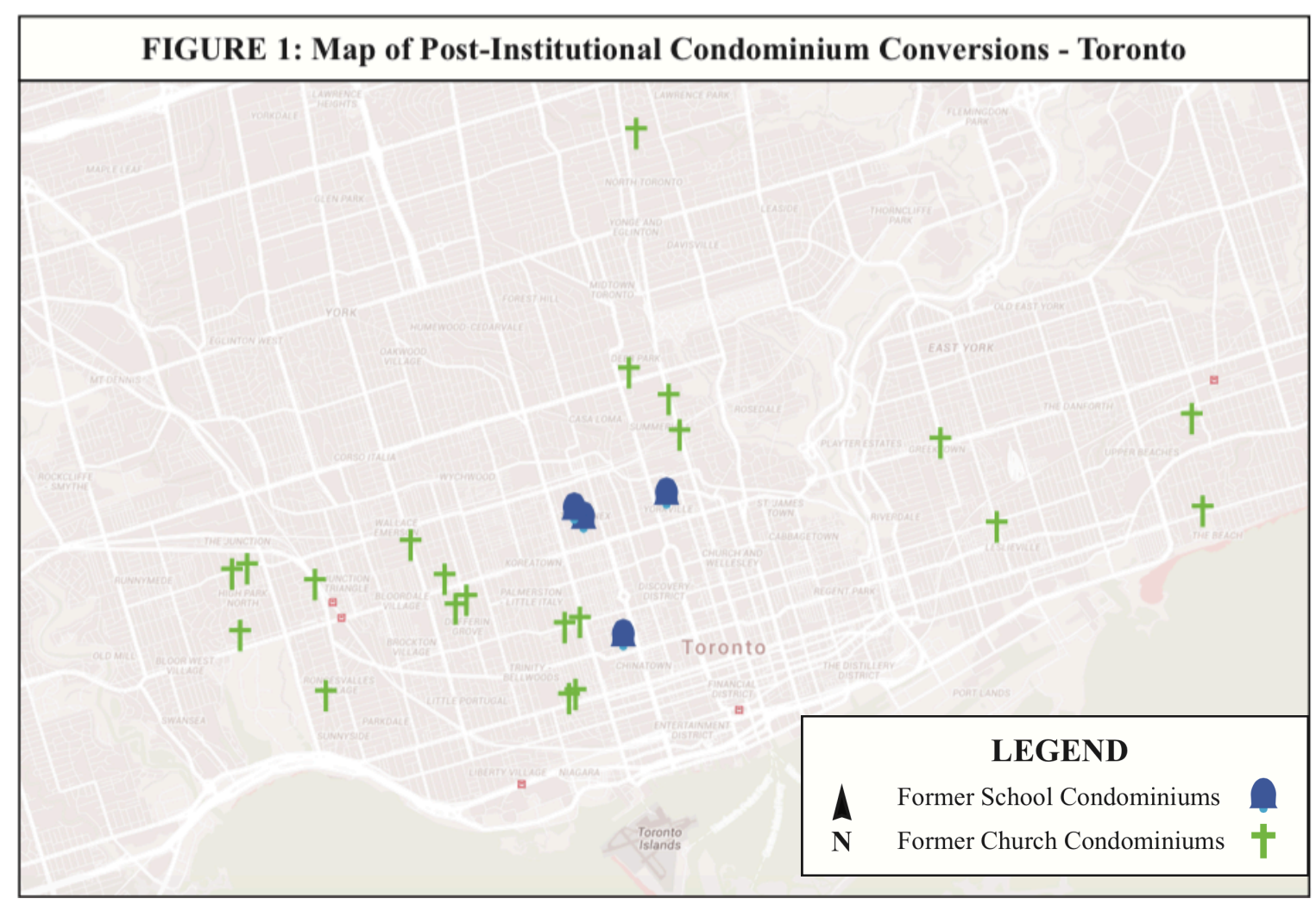

FIGURE 2: Map of Post-Institutional Condominium Conversions - Ottawa

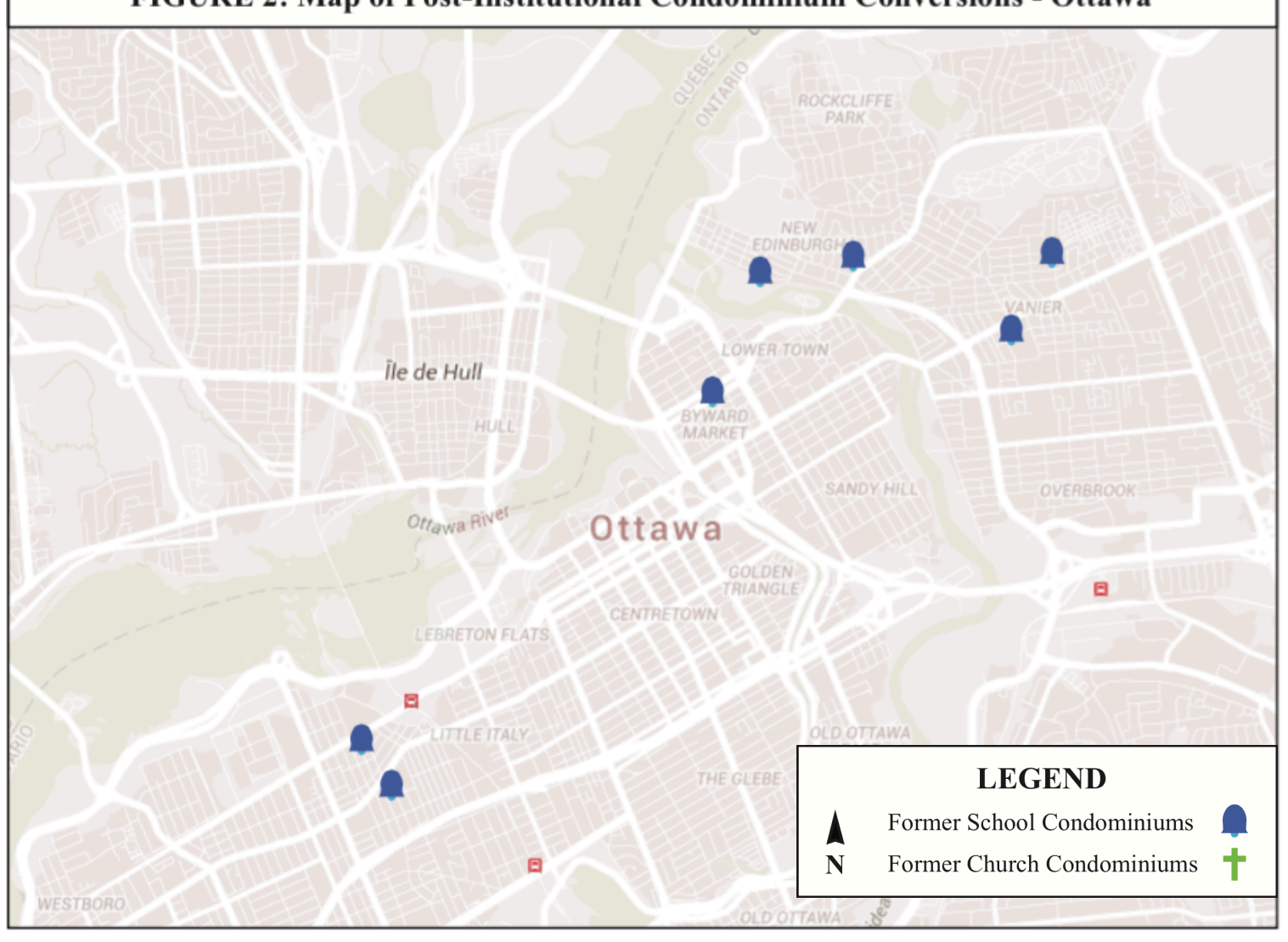




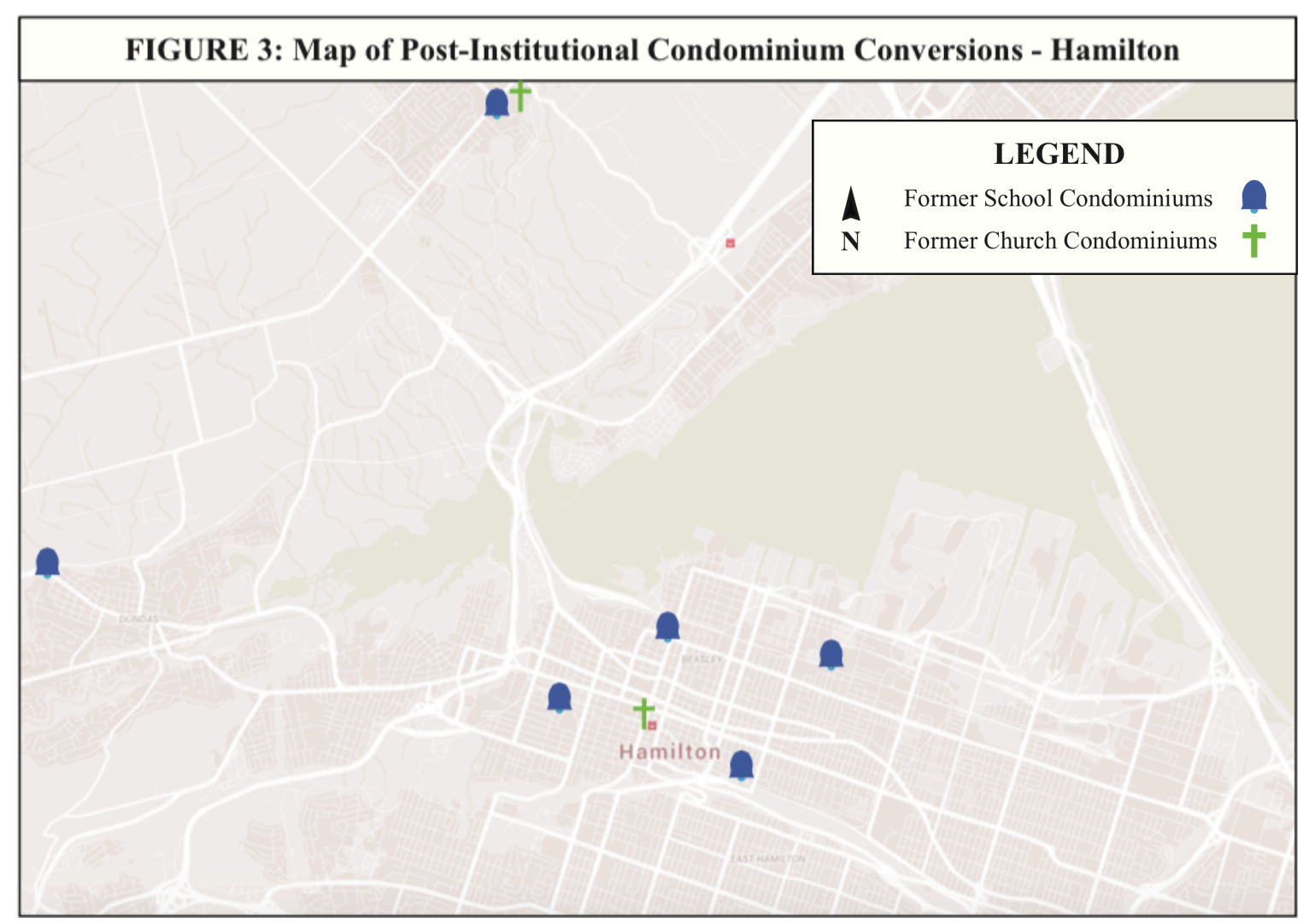

\subsection{Neighbourhood Trends}

Each of the 40 post-institutional neighbourhood condominium conversions was studied within 20-40 years' worth of its neighbourhood context, based on the indicators discussed in Chapter 4. The objective of the research was to pinpoint each conversion's application date either within a process of gentrification, a process of some other type of neighbourhood change, or within a time of stability.

It was possible to identify clear evidence of stability, ongoing gentrification or effectively complete gentrification for the majority of cases in the inventory. Seven cases were located in neighbourhoods that had been stable and wealthy for at least the 20 years prior to the conversion application. An additional seven were located in neighbourhoods where a gentrification process could be observed over a span of years prior to the conversion application, meaning that the conversion was proposed following the effective achievement of gentrification. 13 cases were identified to have been proposed during their respective neighbourhood gentrification processes. 


\section{TABLE 2: Post-Institutional Condominium Conversions within Processes of Neighbourhood Change}

\begin{tabular}{|c|c|c|c|c|}
\hline \multicolumn{2}{|c|}{$\begin{array}{c}\text { WITHIN GENTRIFICATION } \\
\text { PROCESSES }\end{array}$} & \multicolumn{3}{|c|}{ OUTSIDE GENTRIFICATION PROCESSES } \\
\hline EARLY & ONGOING & $\begin{array}{l}\text { IN WEALTHY } \\
\text { NEIGHBOURHOODS }\end{array}$ & $\begin{array}{c}\text { POST- } \\
\text { GENTRIFICATION }\end{array}$ & $\begin{array}{c}\text { IN OTHER } \\
\text { NEIGHBOURHOODS }\end{array}$ \\
\hline The Church Loft & The Channel Club & Archive Square & Macpherson Church Lofts & École Guigues \\
\hline Hepbourne Lofts & Schoolhouse Square & St. George-on-Sheldrake & Woodlawn Church Loft & Les Lofts du Montfort \\
\hline Claremont Hall & Allenby Lofts & Waterdown District High School & The Abbey Lofts & Kensington Market Lofts \\
\hline The Witton Lofts & West40 & St. Thomas Lofts & 36Hazelton & 70 High Park Avenue Condominiums \\
\hline \multirow[t]{9}{*}{ Union Lofts } & The Church Lofts & Bellefair Kew Beach Residences & The Swanwick Heritage Loft & The Glebe Lofts \\
\hline & $\begin{array}{l}\text { College Street Baptist } \\
\text { Church }\end{array}$ & Dundas District Lofts & Victoria Lofts & The Loretto \\
\hline & $\begin{array}{l}\text { St. Clement's Church Lofts } \\
\text { Leslieville }\end{array}$ & Blue Diamond & Park Lofts & Le St-Denis \\
\hline & Sanctuary Lofts & & & École Sacré-Coeur* \\
\hline & & & & Stinson School Lofts* \\
\hline & & & & The Schoolhouse \\
\hline & & & & Yard and Station Lofts* \\
\hline & & & & The Connolly \\
\hline & & & & Gibson School Lofts* \\
\hline \multicolumn{5}{|c|}{$\begin{array}{l}\text { * These condominiums are subject to debate as to their placement in the "Other Neighbourhoods" category. They have potential } \\
\text { to be considered as conversions that occurred early within gentrification processes instead. This issue is explored in further depth } \\
\text { in Section 5.2.1. }\end{array}$} \\
\hline
\end{tabular}

The remaining 13 cases were located in 10 neighbourhoods where the trends in neighbourhood change were less clearly understood. The Glebe Lofts presents one example; it is located in Toronto's North Riverdale neighbourhood, where the indicator data set revealed an apparent gentrification trend, except for the indicator for household size, which showed that the neighbourhood had settled and become stable at an average of 2.5 persons per household. Dantas (1988) has studied the question of North Riverdale's gentrification in some depth. She too found that Riverdale's upgrading process was characterized by families rather than one- to two-person households, and she noted additionally that the housing stock saw modest renovations designed to make houses more liveable rather than an investment in restorations geared toward an increase in property value. As mentioned in Chapter 3 , she commented that these results merited a reconsideration of the small household identifier of gentrification, however her argument has not been universally embraced in the field, and so this paper recognizes North Riverdale's process to be distinct from clear gentrification trends. 
Six other cases in this category occurred in neighbourhoods subject to inconsistent trends, in Toronto's Annex, Kensington Market and High Park neighbourhoods, Hamilton's James Street South corridor, and Ottawa's Byward Market. These neighbourhoods each displayed potential gentrification trends save for their lower-thanaverage household incomes, which did not appear to be rising to meet the municipal medians. In several of these neighbourhoods, this phenomenon may be attributed to high student populations, which might yield university education but low household incomes. These cases may not be identified as having occurred within clear gentrification processes.

\subsubsection{Post-2011 Gentrification Trends}

The last six cases present an interesting research challenge. They fall within four neighbourhoods: the École Sacré-Coeur and Yard and Station Lofts condominiums are located in Ottawa's Hintonburg neighbourhood, the Lofts de Montfort and St-Denis condominiums are found within Ottawa's Vanier neighbourhood, and the Stinson and Gibson School Lofts are located within Hamilton's Stinson and Gibson neighbourhoods respectively. The census data for these neighbourhoods up until 2011 shows no evidence of gentrification within these communities.

In 2011, the Hintonburg neighbourhood featured a household size averaging between one and two people, which had been stable over the 20 years prior. The percentage of 25-44 year olds had been notably high over 20 years, and was just beginning to decline toward municipal levels. The percentage of the population with university degrees had been rising in line with the municipal average, and in 2011 was beginning to surpass the municipality, and while median household incomes were increasing, the municipal median was increasing too, such that the Hintonburg median went from being $\$ 22,000$ to $\$ 33,000$ lower than the municipality over time (Statistics Canada, 1971-2011).

In Vanier, household sizes have been declining since the 1970s, reaching an average of close to two persons per household in the 1990s. The population of 25-44 year olds fluctuates alongside the municipal average, and the university-educated population 
has been consistently rising but continuously falls approximately 10 per cent below the municipal average. Meanwhile, the difference between local and municipal median income levels has grown from $\$ 10,000$ to $\$ 35,000$ over time (Statistics Canada, 19712011).

In Stinson, average household sizes have been stable at two since 1991, 25-44year-old populations have been notably high, university-educated populations have grown in line with the municipal average, however income levels are stagnating, and in 2011 were \$35,000 below the municipal median (Statistics Canada, 1971-2011).

In Gibson, household sizes remain around 2.5 persons per household, 25-44-yearold population statistics are in line with the municipality, university education is very slowly increasing to close the gap with the municipal average, and median income levels are growing, although not as quickly as the municipality; in 2011 , there was a $\$ 21,000$ difference between median income levels in Gibson and those in greater Hamilton. (Statistics Canada, 1971-2011).

However, it is necessary to consider that these four neighbourhoods are locally understood to be either gentrifying or sitting on the cusp of a gentrification process. Fagan's 2010 report on Ottawa's neighbourhood associations identifies both Hintonburg and Vanier as neighbourhoods undergoing such processes of change, specifically discussing the role of the Hintonburg Community Association, the Together for Vanier association and the Vanier Community Association in addressing crime and maintenance issues within their neighbourhoods. Fagan notes that Hintonburg's gentrification process has been in emergence since the mid-1990s, while Vanier's was only just beginning to emerge in the later 2000s. Vanier is acknowledged elsewhere in local journalism to be on the brink of a gentrification process (Radburn, 2011), while local Ottawans recognize both neighbourhoods to be beginning their gentrification processes (T. Marquis, personal communication, March 7, 2016; C. Craig, personal communication, March 7, 2016; I. Cantello, personal communication, March 7, 2016).

In Hamilton, where the city as a whole is understood to be gentrifying as it emerges from its industrial past (Gee, 2015), the Stinson neighbourhood has been compared to Cabbagetown in the 1970s, an archetypical example of a gentrifying 
neighbourhood. A 2009 Globe and Mail article effectively describes the early stage of a gentrification process. John Bentley Mays writes:

The area around Stinson School is one of those old urban places that are politely called "transitional." It may be comparable to Toronto's Cabbagetown district in the 1970s: a zone of fine-looking structures that long ago declined into so many rooming houses, group homes and cheap digs for a disadvantaged population, but that has already caught the eye of people willing to put sweat and money into improvement. (Bentley Mays, 2009)

Northeast of Stinson in the Gibson neighbourhood, recent gentrification trends have been identified as positive markers of neighbourhood change, with a Hamilton Spectator article lauding recent investment in home restorations and condominiums, including a specific nod to the Gibson School Lofts (Wells, 2013). There is local recognition of gentrification processes in these two Hamilton neighbourhoods as well (C. Erl, personal communication, March 7, 2016).

Given that this local knowledge presents a different picture of these neighbourhoods than that revealed in the census data, it is important to remember that the most recent indicator information about these neighbourhoods comes from the unreliable 2011 census, and that the last reliable data is from a full ten years ago, in 2006. With the exception of Vanier's Lofts de Montfort, each of these condominiums has been proposed in the years since the 2006 data was published.

If it is acknowledged that Ottawa's Vanier neighbourhood is only now on the cusp of gentrification, the two condominium projects there may remain in their current category, as their development applications in 1998 and 2007 effectively preclude them from being agents in a gentrification process that is only just beginning 10 years later. However, it must be considered that the condominium applications in Stinson, Gibson and Hintonburg, which were launched in 2010, 2015, and 2008 and 2013 respectively, should be considered as early developments in local processes of neighbourhood change. This study will recognize ground-level knowledge in the face of unreliable quantitative data for the purposes of this paper, and will consider the Stinson School Lofts, the Gibson 
School Lofts, the École Sacré-Coeur and the Yard and Station Lofts to be occurring within the early stages of their neighbourhood gentrification processes.

\subsection{Analysis of the Findings}

The analysis of each case within the post-institutional condominium inventory reveals that 42.5 per cent of cases have fallen within neighbourhood gentrification processes, while 57.5 per cent have fallen outside them.

Of the cases that fell within gentrification processes, 53 per cent fell in the initial stage of the process, while 47 per cent fell later within an active, clear, ongoing period of gentrification. The neighbourhoods in which conversion applications fell early were characterized at the time by below-average household incomes and university education levels, larger household sizes that were just beginning to descend, and growing percentages of 25-44 year olds. Neighbourhoods experiencing established gentrification processes were conversely characterized by some combination of higher but declining 25-44-year-old populations, household sizes that were declining to one to two members, and income and university education levels that were equal to, or had surpassed, levels throughout the greater municipality.

Within gentrification processes, there is effectively an even distribution of conversions that are positioned to spark new gentrification processes, and conversions that have been proposed in neighbourhoods with less associated risk, given their apparent trajectory toward full gentrification. It should additionally be noted that although the early conversions make up 53 per cent of those within gentrification processes, they only represent 22.5 per cent of all post-institutional condominium conversions, which means that the vast majority of post-institutional condominiums are proposed in neighbourhood contexts that are more stable and present less of a risk to investors.

\subsection{Implications of this Research}

There are two major implications of this research. The first is that community institution condominium conversions do not play a single, universalized role within 
neighbourhood gentrification processes. They are not solely drivers of gentrification, but with only 47 per cent occurring later in the process, they are clearly not only reactors either. This contradicts Walks and Maaranen's assertion, quoted in Chapter 1, that converted housing stock development is stimulated primarily through earlier investment in other forms (2008). With almost 60 per cent of post-institutional conversions falling entirely outside gentrification processes as a whole, the research has shown that it is not possible to generalize the influence of these unique condominiums within contexts of neighbourhood change.

The second research implication emerges from the first: if the impact of these conversions cannot be generalized, this means that such conversion proposals do not, as a rule, provoke harmful processes of local displacement and transitions toward neighbourhood exclusivity. A maximum of 22.5 per cent of inventory cases were found to have occurred early within gentrification processes, and this includes the four cases, or 10 per cent, with uncertain status in this category. This means that the other 77.5 per cent of inventory cases occurred either in neighbourhoods where gentrification was not in progress, and where they thus could not play a gentrifying role, or in neighbourhoods where gentrification was already sufficiently in progress that it would have happened regardless of the conversion proposal in question. The majority of post-institutional condominium proposals in Toronto, Ottawa and Hamilton have thus far not driven the displacement of original residents from their neighbourhoods.

This research has been successful in its attempt to confirm, clarify and build on the two works of research that have established the limited scholarship for postinstitutional condominiums within gentrification processes: 1) the discussion of conversions as one of the three types of gentrification housing stock (Walks \& Maaranen, 2008), and; 2) the identification of post-institutional condominiums as gentrification agents in that they are developed for the gentrifying "new urban middle class" (Lynch, 2013).

It has established that with regard to post-institutional conversions specifically, Walks and Maaranen are incorrect that conversions are largely reactive agents within gentrification processes. Post-institutional condominium conversions seem to operate 
similarly to new-build housing developments, which have been proposed at all points throughout neighbourhood gentrification processes (Walks \& Maaranen, 2008).

Lynch, too, may be incorrect to identify post-institutional condominiums as markers of gentrification due to their ostensible target demographic of "new urban middle class" gentrifiers. 17.5 per cent of inventory cases have been proposed in neighbourhoods that have been stable and wealthy for some time, often to the point of being unaffordable for a prototypical gentrifying household. This list includes two high-school conversions in the Hamilton-area communities of Dundas and Waterdown, neither of which exemplify the creative, urban desires that Lynch associates with the demographic for these condominiums. While it is true that the condominium conversions that occur within gentrification processes are likely to further them, this research has established that postinstitutional condominiums cannot be universally recognized as agents of gentrification.

\subsection{Summary of the Findings}

This chapter featured the presentation of the research findings uncovered over the course of this study:

- 40 school and church condominiums were identified in Toronto, Hamilton and Ottawa, and were measured against their neighbourhood contexts over time.

- Only 42.5 per cent of cases were found to have occurred within neighbourhood gentrification processes.

- 52.9 per cent of cases within gentrification processes were found to have occurred early in the process. This means that only 22.5 per cent of all cases occurred early in gentrification processes and had potential to serve as drivers for neighbourhood change. 
- There is no indication that the post-institutional condominium typology plays a standard role as a driver of, or active participant in, neighbourhood gentrification.

The following chapter will conclude this paper with a discussion of the study's greater implications within professional work around heritage and gentrification, as well as an identification of further research directions on post-institutional condominium conversions and gentrification processes. 


\section{CHAPTER 6: BUILDING ON THIS RESEARCH}

\subsection{A Future of Gentrification}

Despite its displacing effects on lower-income residents of inner cities, it appears that gentrification will be a lasting trend. In fact, gentrification in its modern form is spreading across full cities, not only in post-industrial areas, but throughout the world.

Gentrification scholars today have modified Berry's 1985 identification of downtown target areas as "islands of renewal in seas of decay", noting that inner-city neighbourhoods left behind may now be characterized as "islands of decay in seas of renewal" (Wyly \& Hammel, 1999). This has been evident in Ontario's original frontier of gentrification, Toronto, where most residential neighbourhoods in the inner core have become home to a demographic of middle-class gentrifiers (Bain, 2010). As gentrification has spread to consume the post-industrial cities where it first took root, gentrifying influences have emerged throughout the world, driven beyond advanced capitalist states by the technology and globalization of the $21^{\text {st }}$ century (Davidson $\&$ Lees, 2005; Shaw, 2005).

The global emergence and growth of gentrification trends has been facilitated by public policy approaches in the post-1970s neoliberal era. From the 1980s on, postindustrial states saw the downfall of Keynesian economics and welfare-state policies in favour of austerity measures and governments in service of business interests (Hackworth, 2002; Lynch, 2013). Despite the progressive intentions of planners and other public servants today, they are required to work within market-friendly policy contexts under neoliberal regimes (Walks \& August, 2008). Municipal policy now favours tax incentives for private developers to revitalize neighbourhoods, or public-private partnerships toward urban development goals, which has on occasion involved the demolition of inner-core public housing to facilitate private investment in such areas (Hackworth, 2002).

Municipal facilitation of private development along these lines is evident throughout cities in Ontario. In the 1990s, Toronto's planning policies were effectively 
restructured to accelerate gentrification, notably in post-industrial employment lands in the inner core. They were rezoned for mixed uses in an explicit attempt to facilitate industrial conversions. This revitalization strategy has been particularly successful in areas such as Liberty Village, with little institutional concern for the loss of potential future employment spaces for low-skilled workers in large numbers (Keil, 2002; Lehrer \& Wieditz, 2009; Walks \& August, 2008). In other major cities in Ontario, municipal policy is structured toward similar goals. An example can be found in the City of Hamilton's Urban Official Plan, which, in Section 3.4.3, encourages the "intensification and adaptive reuse of commercial and industrial heritage properties", noting that the City may provide developers with reductions on parking and other site amenity requirements in order to facilitate such work (City of Hamilton, 2009).

Within this context of privately-fuelled, municipally-supported gentrification, heritage conservation continues to be undertaken for the benefit of middle- to upper-class consumers. As evidenced in Hamilton's Official Plan, the responsibility of revitalization through heritage restoration has largely been granted to developers with the means to achieve it successfully, but such projects are aimed at the gentry, rather than the original residents of neighbourhoods requiring revitalization (Lynch, 2013). Shaw has noted: "As property developers know all too well, urban conservation can reuse history for the saleable purpose of social distinction," (2005, 63-4), and Lynch concurs, noting that the celebration of built heritage is primarily the privilege of those who can afford to engage with such places -living, shopping or dining in them- once they have been privatized (2013). When community-oriented heritage assets such as schools and churches are privatized, regardless of whether they are located in wealthier or lower-income neighbourhoods, they are no longer part of a shared local history relevant to all city residents across the socioeconomic spectrum.

\subsection{Reflections for Professionals}

What does this mean for planners, policymakers and heritage professionals? As this research has discovered, post-institutional condominium conversions may not directly facilitate neighbourhood gentrification, and they certainly do not exclusively 
occur in lower-income neighbourhoods or those experiencing gentrification processes. However, the research acknowledges that where they do occur in such neighbourhoods, they have potential to provoke indirect displacement as they facilitate shifts in neighbourhood character. In some cases, they are even are proposed with the specific intent of doing so (Arnold, 2016).

When faced with neighbourhood institutions that have outlived their usefulness, planners and heritage professionals should be aware of the potential for gentrifying consequences from post-institutional conversions. Lynch has reflected that municipal heritage regulators have encouraged private-sector redevelopment of such sites as the most effective method of conserving their heritage value; departments like Toronto's Heritage Preservation Services are so burdened with development review that it is easiest to designate such assets with heritage protections, and then pass responsibility to developers with the means to restore them, which most frequently results in private loft condominiums (Lynch, 2013). While municipal heritage planners are primarily responsible for designation and regulation under the Ontario Heritage Act, it could be within the purview of their offices and others within municipal planning services to incentivize the purchase and conversion of community assets by other public or nonprofit organizations (G. Miedema, personal communication, April 6, 2016).

If these loft condominiums do have the power to spark gentrification processes in certain neighbourhoods, it may be advisable for municipal representatives, heritage professionals and institutional bodies (churches and school boards) to consider such alternative conservation strategies, ones that may reflect the once-community-oriented nature of these sites. Lynch discusses the approach to church conversions in Montreal, where the public and non-profit sectors led a city-wide engagement on the future of surplus churches, determining that there was interest in maintaining public access to these former centres of communities (2013). During this process, the city's Catholic diocese instituted a moratorium on church sales, until a consensus on their future direction could be determined (Beaudry, 2015).

If institutions and public-sector actors in Ontario determine that maintaining public uses should be a priority for sites where private conversion may facilitate gentrification, there are alternative approaches that may be available. Institutions are 
subject to constraints in the disposal of their properties; schools in Ontario are required, for instance, to offer their sites to other public institutions for purchase over a ninety-day period prior to releasing them on the private market, while dwindling religious congregations are generally in need of the operations funding that can be gained from the sale of a church property at market value. However, the provincially mandated ninety-day hold for school sales could theoretically be extended, in conjunction with increased efforts toward public engagement around the future of such sites, as recommended by Button and Sauve (2009; 2014). Meanwhile, Hackworth and Gullikson (2013) have indicated that there would likely be state support for congregations choosing to partner with the public sector to convert their churches to affordable housing, as such proposals are ostensibly in line with provincial and municipal policy goals.

In cities where the spread of gentrification is seemingly inevitable, such strategies only begin to graze the surface in helping to prevent its extension to new neighbourhoods. In neighbourhoods at risk of gentrifying, municipal facilitation of community-oriented adaptive reuse projects is only useful in conjunction with broader plans to mitigate gentrification trends. Most scholars agree that the most effective tool in combating gentrification would be a comprehensive affordable housing strategy that ultimately prioritizes the needs of lower-income residents (Walks \& August, 2008; Lees, Slater \& Wyly, 2008), however there is also value in piecemeal guarantees of affordable housing units. Lees, Slater and Wyly mention lower-income housing unit quotas for developers, where the units are built into market developments at a similar level of quality (2008). Another option is targeted at condominium conversions, where a zero-netloss policy requires the developer to replace any lost affordable units in close proximity to the new development; this is a strategy employed toward industrial adaptive reuse projects in Los Angeles (Young, 2009), as well as in securing residential units for artists in Toronto (Hutton, 2014).

Walks and August (2008) have also suggested some policy recommendations based off their study of two Toronto neighbourhoods that withstood gentrification for much longer than expected. Their recommendations include the maintenance of employment lands in proximity to neighbourhoods, and the facilitation of what they call "institutionally complete ethnic communities" and any architectural alterations those 
communities may pursue; both strategies are geared toward deterring interest from would-be gentrifiers. They emphasize, however, that these recommendations are intended to complement a comprehensive municipal affordable housing program.

There are evidently strategies that exist for planners, policymakers, community institutions and heritage professionals in the promotion of built heritage conservation toward still-equitable planning goals. The ideas presented in this section should be understood as reflections rather than recommendations, given that this research has been largely exploratory and not sufficiently conclusive as to inform policy. The primary lesson for professionals should be that developer-driven condominium conversions do not yield the same consequences across the board; each case's role within neighbourhood change is largely dependent on its existing neighbourhood context. When faced with future proposals for condominium conversions, regulators should carefully consider the existing contexts, with the awareness that a conversion might serve as an agent of gentrification in neighbourhoods on the cusp of such processes.

\subsection{Reflections for Academics}

Scholars on heritage, adaptive reuse and gentrification have an important role to play in encouraging responsible and equitable planning in the public sector, and in finding new ways to promote heritage conservation while mitigating the associated element of exclusivity. Municipal regulators and policymakers are less likely to act to prevent gentrification through the private redevelopment of heritage assets, given the incentives of raised property tax revenues and economic competitiveness on the world stage. The academic field should thus be encouraged to continue investigating and publicizing its findings on the consequences of adaptive reuse and gentrification.

These academic scholars are the intended audience for the research presented in this paper; they are invited to consider and build on this research as they continue to explore the exclusivity associated with private loft conversions of formerly shared heritage assets. They are particularly welcome to expand on the research in order to confirm or review the findings presented here. There are two questions in particular that might benefit from such confirmation or clarification. 
First, the identification of trends in neighbourhood change was necessarily generalized, given the time and capacity constraints of this research. There is certainly justification for a more rigorous statistical analysis of each of the indicators, and the changes between indicators, that were used to identify gentrification processes and the stages within them. A researcher looking to study this in more depth might select a category of inventory cases from this study, for instance those from one of the three cities, in order to more accurately identify the gentrification processes.

These research findings should additionally be confirmed through a second study following the release of Canada's 2016 census data, which will offer the first legitimate information on income and education levels since 2006. A full 50 per cent of cases in the inventory were proposed after the release of the 2006 data, which brings their categorization into question, given the unreliability of the 2011 census data. For the 15 per cent of cases proposed after 2011, there is as of yet even less legitimate information on gentrification trends in their local neighbourhoods. A successive study would serve to confirm or clarify any apparent gentrification trends identified through this research.

Beyond the expansion of the research presented in this paper, there are several additional research directions that might be pursued to further explore the intersection of heritage and gentrification.

Another exploratory study might investigate the relationship between gentrification processes and the loss of a community institution such as a church or a school, examining the functions these institutions served beyond their educational or religious uses, and identifying the emerging community institutions geared toward the incoming populations that are intended to meet these needs instead.

A team of researchers with greater capacity might attempt to investigate the social mix in neighbourhoods featuring post-institutional condominium conversions, building off the hypothesis that a condominium conversion such as the St. George-on-Sheldrake in a stable and wealthy neighbourhood such as North Toronto might in fact present an appropriate way for older neighbourhood residents to age in place. Such a study could identify condominium conversions in diverse socioeconomic contexts, and compare the social mix between condominium and neighbourhood residents, studying whether the same businesses are patronized and services used. This sort of study might help 
policymakers to identify the more and less appropriate neighbourhoods in which to facilitate post-institutional condominium conversions.

Most importantly, heritage and adaptive reuse scholars such as Shipley or Bullen and Love should focus not only on encouraging developers to pursue such projects, but also on investigating the feasibility of adaptive reuse projects from within the public sector. Such projects might facilitate investment in lower-income neighbourhoods while continuing to provide public services and access to built heritage assets for the existing neighbourhood residents. There has been very little research conducted on the role of the state as an actor rather than a regulator or facilitator in restoration and adaptive reuse projects, despite the numerous high-profile cases that exist. ${ }^{8}$ These scholars might aim to investigate the financial viability of existing public-sector adaptive reuse projects as has been done for similar developer-led projects (see Shipley, Utz \& Parsons, 2006) in order to determine how the state might best undertake such projects in the future.

Another approach might involve comparing the cases in which community institutions have been converted as private lofts to those instances where similar ones have been converted to affordable or social housing. There are certainly current examples of post-institutional affordable housing projects, for instance the Dalhousie Church Lofts in Brantford, Ontario (Canadian Mortgage and Housing Corporation, 2006) or the numerous schools in Montreal purchased by the municipality for social housing conversion (Lynch, 2013). A researcher could investigate the reasons for privatization in certain situations but not in others in order to determine ways to facilitate public-sector involvement in future post-institutional reuse projects.

These are only some of the many ways through which future researchers might examine the intersection of heritage and gentrification. Given the exploratory nature of the research presented this paper, scholars are encouraged to expand on this research in service of more equitable conservation and access to built heritage assets in gentrifying cities.

\subsection{Moving Forward}

\footnotetext{
${ }^{8}$ Some Toronto-based examples include the Toronto Public Library's Bloor-Gladstone branch restoration and the Toronto Police Services' factory adaptive reuse toward the 51 Division.
} 
The objective of this research has been to identify the role of loft conversions of former neighbourhood institutions in gentrification processes, with the overarching goal of determining how they should be considered in future academic study as well as in planning policy and development review. The research has expanded on the limited existing scholarship on loft conversions within gentrification processes (see Walks and Maaranen, 2008) and specifically on post-institutional loft conversions as agents of gentrification (see Lynch, 2013) in order to more specifically understand how these conversions either drive or react to gentrification processes. The results of this preliminary study indicate that post-institutional loft conversions are not constrained to gentrification processes, and where they do take place within such processes, they may serve as either drivers or reactors. There are no clear trends as to at what point in processes of neighbourhood change a developer is most likely to propose a postinstitutional loft conversion. Further research is recommended in order to confirm the results of the study and to better understand the impact of community institution loss to private, exclusive uses.

Municipalities in Ontario are experiencing a growing trend in the adaptive reuse of former community institutions as condominiums. The inventory in this research shows a rapid increase in such developments, with four proposed in the 1980s, nine in the 1990s, 15 in the 2000s and already 12 over the first half of the current decade. This trend is only likely to increase as churches are faced with declining attendance due to secularization, and schools with changing neighbourhood demographics throughout Canadian cities (Ley \& Martin, 1993; Hutton, 2014; Rushowy \& Brown, 2015).

As this trend becomes an increasingly prevalent response to the closure of institutions throughout inner-city neighbourhoods, it will be imminently necessary for municipalities to understand not only the influence of such conversions in processes of displacement and neighbourhood change, but also the success, or lack thereof, they have had in achieving municipal goals of heritage conservation and commemoration. In striving to protect built heritage in the face of mounting development pressures, municipalities must not lose sight of for whom they are protecting these assets. Even the aesthetic value of such landmarks may no longer be enjoyed by residents across the 
socioeconomic spectrum if exclusive conversions foster increasingly exclusive residential surroundings. If heritage conservation goals are achieved but only the wealthiest members of society may access and connect with what remains, we should consider whether these stories in our landscapes are worth preserving at all. 
APPENDIX A:

List of Post-Institutional Condominium Conversions

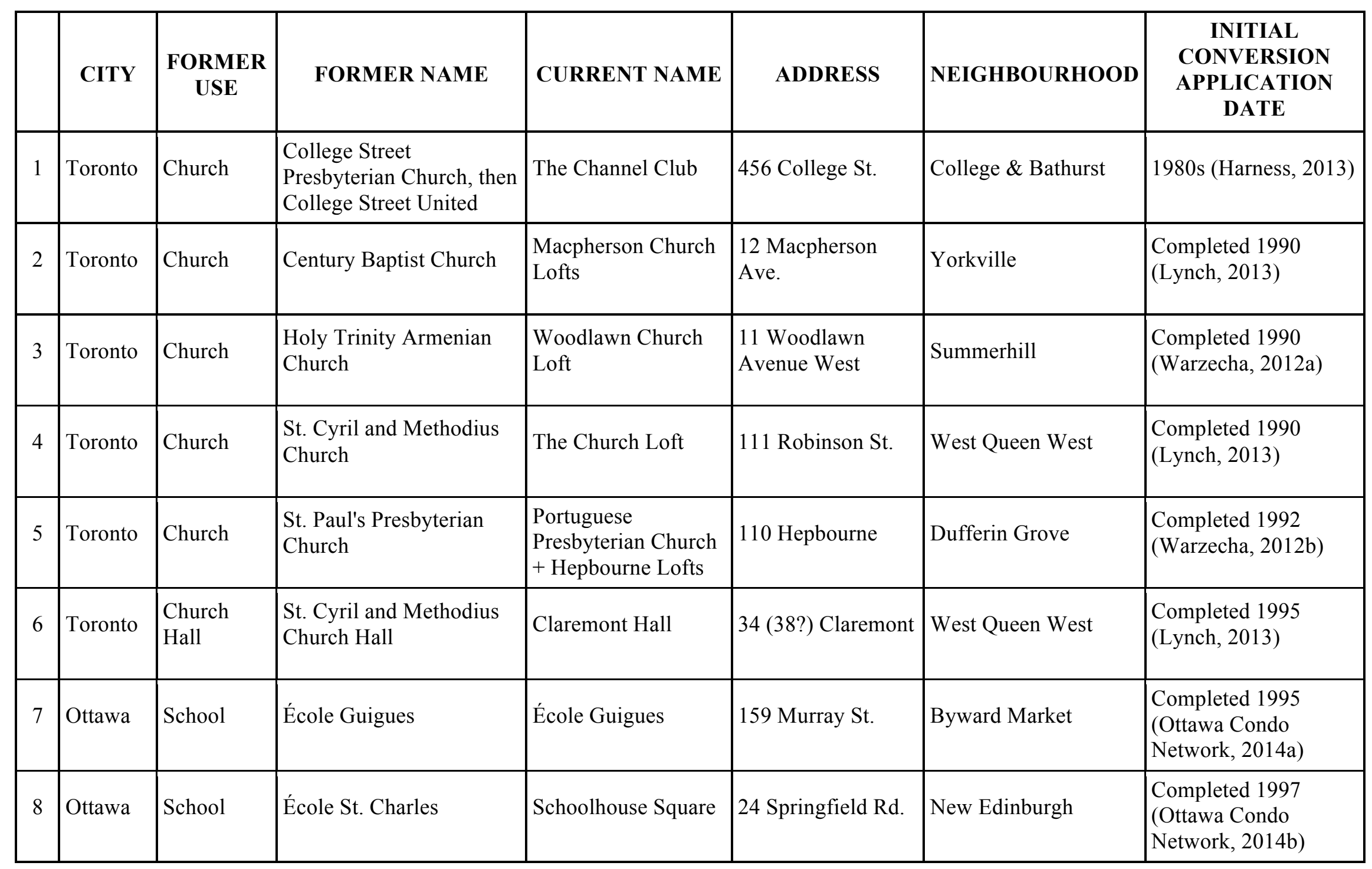




\begin{tabular}{|c|c|c|c|c|c|c|c|}
\hline 9 & Ottawa & School & École Montfort & $\begin{array}{l}\text { Les Lofts du } \\
\text { Montfort }\end{array}$ & 297 Dupuis St & Vanier & $\begin{array}{l}\text { Completed } 1998 \\
\text { (Ottawa Condo } \\
\text { Network, 2014c) }\end{array}$ \\
\hline 10 & Ottawa & School & $\begin{array}{l}\text { St. Vincent de Paul } \\
\text { School / St. Aloysius } \\
\text { School }\end{array}$ & Archive Square & 174 Stanley Ave & New Edinburgh & 1999 (Ngoh, 2009) \\
\hline 11 & Toronto & School & $\begin{array}{l}\text { William Houston Public } \\
\text { School }\end{array}$ & $\begin{array}{l}\text { Kensington Market } \\
\text { Lofts }\end{array}$ & $\begin{array}{l}21 \text { Nassau St (160 } \\
\text { Baldwin) }\end{array}$ & Kensington Market & 1999 (White, 2014) \\
\hline 12 & Toronto & Church & Eglinton United Church & $\begin{array}{l}\text { St. George on } \\
\text { Sheldrake }\end{array}$ & 65 Sheldrake Blvd. & North Toronto & $\begin{array}{l}\text { Completed 2001 } \\
\text { (Lynch, 2013) }\end{array}$ \\
\hline 13 & Hamilton & School & $\begin{array}{l}\text { Waterdown District High } \\
\text { School }\end{array}$ & $\begin{array}{l}\text { Waterdown District } \\
\text { High School }\end{array}$ & 262 Dundas St E & Waterdown & $\begin{array}{l}2001 \text { (City of } \\
\text { Hamilton, 2001) }\end{array}$ \\
\hline 15 & Toronto & Church & $\begin{array}{l}\text { Riverdale Presbyterian } \\
\text { Church }\end{array}$ & The Glebe Lofts & 660-662 Pape Ave. & Riverdale & $\begin{array}{l}2001 \text { (City of Toronto, } \\
\text { 2001b) }\end{array}$ \\
\hline 16 & Toronto & Church & $\begin{array}{l}\text { Emmanuel Howard Park } \\
\text { United Church }\end{array}$ & The Abbey Lofts & $\begin{array}{l}384 \text { Sunnyside } \\
\text { Ave. }\end{array}$ & Roncesvalles & $\begin{array}{l}2002 \text { (City of Toronto, } \\
\text { 2002) }\end{array}$ \\
\hline 17 & Hamilton & School & Allenby School & Allenby Lofts & $\begin{array}{l}357 \text { Hunter Street } \\
\text { W }\end{array}$ & Kirkendall & $\begin{array}{l}2002 \text { (City of } \\
\text { Hamilton, 2002) }\end{array}$ \\
\hline 18 & Toronto & Church & $\begin{array}{l}\text { Church of St. Mary the } \\
\text { Virgin and St. Cyprian }\end{array}$ & West 40 & $\begin{array}{l}40 \text { Westmoreland } \\
\text { Ave. }\end{array}$ & Dovercourt Park & $\begin{array}{l}\text { 2003-2004 (City of } \\
\text { Toronto, 2012b) }\end{array}$ \\
\hline
\end{tabular}




\begin{tabular}{|c|c|c|c|c|c|c|c|}
\hline 19 & Toronto & School & $\begin{array}{l}\text { St. Basil's Separate } \\
\text { School }\end{array}$ & 36Hazelton & $\begin{array}{l}\text { 34-38 Hazelton } \\
\text { Ave. }\end{array}$ & Yorkville & $\begin{array}{l}2006 \text { (City of Toronto, } \\
2009 \text { a) }\end{array}$ \\
\hline 20 & Toronto & School & Loretto College School & The Loretto & $\begin{array}{l}387 \text { Brunswick } \\
\text { Ave. }\end{array}$ & The Annex & $\begin{array}{l}\text { Completed } 2007 \\
\text { (Kulig, 2010) }\end{array}$ \\
\hline 21 & Ottawa & School & École Cadieux & Le St-Denis & 345 St-Denis St. & Vanier & $\begin{array}{l}2007 \text { (City of Ottawa, } \\
\text { 2007) }\end{array}$ \\
\hline 22 & Toronto & Church & $\begin{array}{l}\text { Centennial Methodist } \\
\text { Church, then Centennial } \\
\text { Japanese Church }\end{array}$ & The Church Lofts & $\begin{array}{l}\text { 701-703 } \\
\text { Dovercourt Rd. }\end{array}$ & Dufferin Grove & $\begin{array}{l}2007 \text { (City of Toronto, } \\
\text { 2007) }\end{array}$ \\
\hline 23 & Toronto & Church & $\begin{array}{l}\text { Emmanuel Presbyterian } \\
\text { Church }\end{array}$ & $\begin{array}{l}\text { The Swanwick } \\
\text { Heritage Loft }\end{array}$ & 21 Swanwick Ave. & Upper Beaches & $\begin{array}{l}2007-2008 \text { (City of } \\
\text { Toronto, 2008a) }\end{array}$ \\
\hline 25 & Ottawa & School & École Sacré-Coeur & École Sacré-Coeur & 19 Melrose Ave. & Hintonburg & $\begin{array}{l}\text { Completed } 2009 \\
\text { (Ottawa Condo } \\
\text { Network, 2014d) }\end{array}$ \\
\hline 26 & Toronto & Church & $\begin{array}{l}\text { West Toronto } \\
\text { Presbyterian Church, then } \\
\text { Victoria Royce }\end{array}$ & Victoria Lofts & 152 Annette St. & The Junction & $\begin{array}{l}2008 \text { (City of Toronto, } \\
\text { 2008b) }\end{array}$ \\
\hline 27 & Toronto & Church & Bellefair United Church & $\begin{array}{l}\text { Bellefair Kew Beach } \\
\text { Residences }\end{array}$ & 2 Bellefair Ave. & The Beach & $\begin{array}{l}\text { 2008-2011 (Lynch, } \\
\text { 2013) }\end{array}$ \\
\hline 28 & Toronto & Church & $\begin{array}{l}\text { College Street Baptist } \\
\text { Church, then the } \\
\text { Portuguese Seventh-Day }\end{array}$ & 4 residential homes & 506 College Street & College \& Bathurst & $\begin{array}{l}\text { Conversion in } \\
\text { Progress } 2009 \text { (City of } \\
\text { Toronto, 2009b) }\end{array}$ \\
\hline
\end{tabular}




\begin{tabular}{|c|c|c|c|c|c|c|c|}
\hline 29 & Toronto & School & Loretto College School & The Schoolhouse & $\begin{array}{l}391 \text { Brunswick } \\
\text { Ave. }\end{array}$ & The Annex & 2010 (Kulig, 2010) \\
\hline 30 & Hamilton & School & $\begin{array}{l}\text { Dundas District High } \\
\text { School }\end{array}$ & $\begin{array}{l}\text { Dundas District } \\
\text { Lofts }\end{array}$ & $\begin{array}{l}397 \text { King St. W., } \\
\text { Dundas }\end{array}$ & Colborne & $\begin{array}{l}2010 \text { (City of } \\
\text { Hamilton, 2010a) }\end{array}$ \\
\hline 31 & Hamilton & School & Stinson School & Stinson School Lofts & 200 Stinson St. & Stinson & $\begin{array}{l}2010 \text { (City of } \\
\text { Hamilton, 2010b) }\end{array}$ \\
\hline 32 & Toronto & Church & $\begin{array}{l}\text { Czechoslovak Baptist } \\
\text { Church, then Annette } \\
\text { Street Baptist Church }\end{array}$ & Park Lofts & 200 Annette Street & The Junction & $\begin{array}{l}2010 \text { (City of Toronto, } \\
2010 \text { b) }\end{array}$ \\
\hline 33 & Toronto & Church & $\begin{array}{l}\text { St. Clement's Anglican } \\
\text { Church }\end{array}$ & $\begin{array}{l}\text { St. Clement's Church } \\
\text { Lofts Leslieville OR } \\
\text { St. Leslieville }\end{array}$ & 173-175 Jones Ave. & Leslieville & $\begin{array}{l}2010 \text { (City of Toronto, } \\
\text { 2010a) }\end{array}$ \\
\hline 34 & Hamilton & School & McIlwraith Public School & The Witton Lofts & 50 Murray St. W. & Central & $\begin{array}{l}2011 \text { (City of } \\
\text { Hamilton, 2012) }\end{array}$ \\
\hline 35 & Toronto & Church & $\begin{array}{l}\text { Dufferin Street United } \\
\text { Church, then H.O.P.E. } \\
\text { Centre }\end{array}$ & Sanctuary Lofts & 1183 Dufferin St. & Dovercourt Park & $\begin{array}{l}2012 \text { (City of Toronto, } \\
\text { 2012d) }\end{array}$ \\
\hline 36 & Toronto & Church & $\begin{array}{l}\text { Toronto Perth Avenue } \\
\text { Adventist Church }\end{array}$ & Union Lofts & 243 Perth Ave. & Junction Triangle & $\begin{array}{l}2012 \text { (City of Toronto, } \\
2012 \mathrm{c})\end{array}$ \\
\hline 37 & Toronto & Church & Deer Park United Church & Blue Diamond & $\begin{array}{l}129 \text { St. Clair Ave. } \\
\text { W. }\end{array}$ & Deer Park & $\begin{array}{l}2012 \text { (City of Toronto, } \\
\text { 2012a) }\end{array}$ \\
\hline 38 & Ottawa & School & $\begin{array}{l}\text { St. Francois D'Assise } \\
\text { Separate School }\end{array}$ & $\begin{array}{l}\text { Yard and Station } \\
\text { Lofts }\end{array}$ & 12-24 Stirling Ave & Hintonburg & 2013 (Mills, 2014) \\
\hline
\end{tabular}




\begin{tabular}{|l|l|l|l|l|l|l|l|}
39 & Hamilton & Church & $\begin{array}{l}\text { James Street Baptist } \\
\text { Church }\end{array}$ & The Connolly & 98 James St. S. & James Street South & $\begin{array}{l}2015 \text { (City of } \\
\text { Hamilton, 2015a) }\end{array}$ \\
\hline 40 & Hamilton & School & $\begin{array}{l}\text { Joseph A. Gibson Public } \\
\text { School }\end{array}$ & Gibson School Lofts & 601 Barton St. E. & Gibson & $\begin{array}{l}2015 \text { (City of } \\
\text { Hamilton, 2015b) }\end{array}$ \\
\hline
\end{tabular}


APPENDIX B:

Gentrification Indicators Analysis

\begin{tabular}{|c|c|c|c|c|c|c|c|c|c|c|c|c|c|c|c|}
\hline \multirow[b]{2}{*}{ City } & \multirow{2}{*}{$\begin{array}{c}\text { Condominium } \\
\text { Name }\end{array}$} & \multirow[b]{2}{*}{ Neighbourhood } & \multirow{2}{*}{$\begin{array}{l}\text { Initial Conversion } \\
\text { Application Date }\end{array}$} & \multirow[b]{2}{*}{ CMA } & \multirow{2}{*}{$\begin{array}{l}\text { Census } \\
\text { Tract }\end{array}$} & \multirow{2}{*}{$\begin{array}{l}\text { Time } \\
\text { Span }\end{array}$} & \multirow[b]{2}{*}{ Year } & \multicolumn{4}{|c|}{ Neighbourhood } & \multicolumn{4}{|c|}{ City } \\
\hline & & & & & & & & $\begin{array}{c}\text { Avg. \# } \\
\text { Persons/ } \\
\text { Household }\end{array}$ & $\begin{array}{c}\% \text { of Pop. } \\
\text { with } \\
\text { University } \\
\text { Degrees }\end{array}$ & $\begin{array}{l}\text { Median } \\
\text { Household } \\
\text { Income }\end{array}$ & $\begin{array}{l}\text { \% of } \\
\text { Pop. } \\
25-44\end{array}$ & $\begin{array}{c}\text { Avg. \# } \\
\text { Persons/ } \\
\text { Household }\end{array}$ & $\begin{array}{c}\% \text { of Pop. } \\
\text { with } \\
\text { University } \\
\text { Degrees }\end{array}$ & $\begin{array}{l}\text { Median } \\
\text { Household } \\
\text { Income }\end{array}$ & $\begin{array}{l}\text { \% of } \\
\text { Pop. } \\
25-44\end{array}$ \\
\hline \multirow[t]{5}{*}{ Toronto } & $\begin{array}{l}\text { Bellefair Kew } \\
\text { Beach } \\
\text { Residences }\end{array}$ & The Beach & $\begin{array}{c}\text { Conversion in } \\
\text { Progress (Lynch, } \\
\text { 2013) }\end{array}$ & 535 & 0024.00 & $\begin{array}{l}1991- \\
2011\end{array}$ & 1991 & 2.2 & $23 \%$ & $\$ 49,686.00$ & $46 \%$ & 2.6 & $15 \%$ & $\$ 43,212.00$ & $36 \%$ \\
\hline & & & & & & & 1996 & 2.2 & $25 \%$ & $\$ 51,143.00$ & $45 \%$ & 2.6 & $17 \%$ & $\$ 40,443.00$ & $35 \%$ \\
\hline & & & & & & & 2001 & 2.2 & $30 \%$ & $\$ 62,067.00$ & $42 \%$ & 2.6 & $21 \%$ & $\$ 49,345.00$ & $34 \%$ \\
\hline & & & & & & & 2006 & 2.2 & $39 \%$ & $\$ 65,149.00$ & $38 \%$ & 2.5 & $24 \%$ & $\$ 52,833.00$ & $32 \%$ \\
\hline & & & & & & & 2011 & 2.2 & $39 \%$ & $\$ 81,017.00$ & $34 \%$ & 2.5 & $27 \%$ & $\$ 58,381.00$ & $31 \%$ \\
\hline \multirow[t]{5}{*}{ Toronto } & $\begin{array}{l}\text { St. Clement's } \\
\text { Church Lofts } \\
\text { Leslieville }\end{array}$ & Leslieville & $\begin{array}{c}2010 \text { (City of Toronto, } \\
\text { 2010a) }\end{array}$ & 535 & 0027.00 & $\begin{array}{l}1991- \\
2011\end{array}$ & 1991 & 2.9 & $10 \%$ & $\$ 39,433.00$ & $38 \%$ & 2.6 & $15 \%$ & $\$ 43,212.00$ & $36 \%$ \\
\hline & & & & & & & 1996 & 2.8 & $8 \%$ & $\$ 32,808.00$ & $37 \%$ & 2.6 & $17 \%$ & $\$ 40,443.00$ & $35 \%$ \\
\hline & & & & & & & 2001 & 2.7 & $18 \%$ & $\$ 42,505.00$ & $37 \%$ & 2.6 & $21 \%$ & $\$ 49,345.00$ & $34 \%$ \\
\hline & & & & & & & 2006 & 2.6 & $22 \%$ & $\$ 42,136.00$ & $35 \%$ & 2.5 & $24 \%$ & $\$ 52,833.00$ & $32 \%$ \\
\hline & & & & & & & 2011 & 2.5 & $26 \%$ & $\$ 63,104.00$ & $34 \%$ & 2.5 & $27 \%$ & $\$ 58,381.00$ & $31 \%$ \\
\hline \multirow[t]{2}{*}{ Toronto } & $\begin{array}{l}\text { Kensington } \\
\text { Market Lofts }\end{array}$ & $\begin{array}{l}\text { Kensington } \\
\text { Market }\end{array}$ & 1999 (White, 2014) & 535 & 0038.00 & $\begin{array}{l}1981- \\
2011\end{array}$ & 1981 & 3.2 & $6 \%$ & $\$ 15,120.00$ & $27 \%$ & 2.7 & $10 \%$ & $\$ 23,301.00$ & $30 \%$ \\
\hline & & & & & & & 1986 & 3.2 & $9 \%$ & $\$ 24,406.00$ & $31 \%$ & 2.6 & $12 \%$ & $\$ 33,231.00$ & $33 \%$ \\
\hline
\end{tabular}




\begin{tabular}{|c|c|c|c|c|c|c|c|c|c|c|c|c|c|c|c|}
\hline & & & & & & & 1991 & 2.9 & $14 \%$ & $\$ 26,547.00$ & $38 \%$ & 2.6 & $15 \%$ & $\$ 43,212.00$ & $36 \%$ \\
\hline & & & & & & & 1996 & 2.6 & $14 \%$ & $\$ 20,612.00$ & $40 \%$ & 2.6 & $17 \%$ & $\$ 40,443.00$ & $35 \%$ \\
\hline & & & & & & & 2001 & 2.4 & $25 \%$ & $\$ 34,472.00$ & $43 \%$ & 2.6 & $21 \%$ & $\$ 49,345.00$ & $34 \%$ \\
\hline & & & & & & & 2006 & 2.4 & $25 \%$ & $\$ 34,472.00$ & $32 \%$ & 2.5 & $24 \%$ & $\$ 52,833.00$ & $32 \%$ \\
\hline & & & & & & & 2011 & 2.2 & $28 \%$ & $\$ 36,258.00$ & $39 \%$ & 2.5 & $27 \%$ & $\$ 58,381.00$ & $31 \%$ \\
\hline \multirow[t]{8}{*}{ Toronto } & Claremont Hall & $\begin{array}{l}\text { West Queen } \\
\text { West }\end{array}$ & 1995 (Lynch, 2013) & 535 & 0040.00 & $\begin{array}{l}1976- \\
2011\end{array}$ & 1976 & no census & no census & no census & $\begin{array}{c}\text { no } \\
\text { census }\end{array}$ & no census & no census & no census & $\begin{array}{c}\text { no } \\
\text { census }\end{array}$ \\
\hline & & & & & & & 1981 & 3.8 & $2 \%$ & $\$ 20,432.00$ & $25 \%$ & 2.7 & $10 \%$ & $\$ 23,301.00$ & $30 \%$ \\
\hline & & & & & & & 1986 & 3.9 & $5 \%$ & $\$ 32,312.00$ & $28 \%$ & 2.6 & $12 \%$ & $\$ 33,231.00$ & $33 \%$ \\
\hline & & & & & & & 1991 & 3 & $10 \%$ & $\$ 36,192.00$ & $35 \%$ & 2.6 & $15 \%$ & $\$ 43,212.00$ & $36 \%$ \\
\hline & & & & & & & 1996 & 3 & $12 \%$ & $\$ 34,498.00$ & $39 \%$ & 2.6 & $17 \%$ & $\$ 40,443.00$ & $35 \%$ \\
\hline & & & & & & & 2001 & 2.8 & $17 \%$ & $\$ 44,919.00$ & $42 \%$ & 2.6 & $21 \%$ & $\$ 49,345.00$ & $34 \%$ \\
\hline & & & & & & & 2006 & 2.6 & $26 \%$ & $\$ 51,915.00$ & $40 \%$ & 2.5 & $24 \%$ & $\$ 52,833.00$ & $32 \%$ \\
\hline & & & & & & & 2011 & 2.7 & $29 \%$ & $\$ 57,370.00$ & $39 \%$ & 2.5 & $27 \%$ & $\$ 58,381.00$ & $31 \%$ \\
\hline \multirow[t]{5}{*}{ Toronto } & $\begin{array}{l}\text { The Church } \\
\text { Loft }\end{array}$ & $\begin{array}{c}\text { West Queen } \\
\text { West }\end{array}$ & 1990 (Lynch, 2013) & 535 & 0040.00 & $\begin{array}{l}1976- \\
2011\end{array}$ & 1976 & no census & no census & no census & $\begin{array}{c}\text { no } \\
\text { census }\end{array}$ & no census & no census & no census & $\begin{array}{c}\text { no } \\
\text { census }\end{array}$ \\
\hline & & & & & & & 1981 & 3.8 & $2 \%$ & $\$ 20,432.00$ & $25 \%$ & 2.7 & $10 \%$ & $\$ 23,301.00$ & $30 \%$ \\
\hline & & & & & & & 1986 & 3.9 & $5 \%$ & $\$ 32,312.00$ & $28 \%$ & 2.6 & $12 \%$ & $\$ 33,231.00$ & $33 \%$ \\
\hline & & & & & & & 1991 & 3 & $10 \%$ & $\$ 36,192.00$ & $35 \%$ & 2.6 & $15 \%$ & $\$ 43,212.00$ & $36 \%$ \\
\hline & & & & & & & 1996 & 3 & $12 \%$ & $\$ 34,498.00$ & $39 \%$ & 2.6 & $17 \%$ & $\$ 40,443.00$ & $35 \%$ \\
\hline
\end{tabular}




\begin{tabular}{|c|c|c|c|c|c|c|c|c|c|c|c|c|c|c|c|}
\hline & & & & & & & 2001 & 2.8 & $17 \%$ & $\$ 44,919.00$ & $42 \%$ & 2.6 & $21 \%$ & $\$ 49,345.00$ & $34 \%$ \\
\hline & & & & & & & 2006 & 2.6 & $26 \%$ & $\$ 51,915.00$ & $40 \%$ & 2.5 & $24 \%$ & $\$ 52,833.00$ & $32 \%$ \\
\hline & & & & & & & 2011 & 2.7 & $29 \%$ & $\$ 57,370.00$ & $39 \%$ & 2.5 & $27 \%$ & $\$ 58,381.00$ & $31 \%$ \\
\hline \multirow[t]{7}{*}{ Toronto } & $\begin{array}{c}\text { The Abbey } \\
\text { Lofts }\end{array}$ & Roncesvalles & $\begin{array}{c}2002 \text { (City of Toronto, } \\
\text { 2002) }\end{array}$ & 535 & 0051.00 & $\begin{array}{l}1981- \\
2011\end{array}$ & 1981 & 2.5 & $17 \%$ & $\$ 21,595.00$ & $39 \%$ & 2.7 & $10 \%$ & $\$ 23,301.00$ & $30 \%$ \\
\hline & & & & & & & 1986 & 2.3 & $21 \%$ & $\$ 30,221.00$ & $43 \%$ & 2.6 & $12 \%$ & $\$ 33,231.00$ & $33 \%$ \\
\hline & & & & & & & 1991 & 2.2 & $29 \%$ & $\$ 40,613.00$ & $44 \%$ & 2.6 & $15 \%$ & $\$ 43,212.00$ & $36 \%$ \\
\hline & & & & & & & 1996 & 2.2 & $33 \%$ & $\$ 45,382.00$ & $44 \%$ & 2.6 & $17 \%$ & $\$ 40,443.00$ & $35 \%$ \\
\hline & & & & & & & 2001 & 2.1 & $38 \%$ & $\$ 50,399.00$ & $43 \%$ & 2.6 & $21 \%$ & $\$ 49,345.00$ & $34 \%$ \\
\hline & & & & & & & 2006 & 2.2 & $47 \%$ & $\$ 60,843.00$ & $39 \%$ & 2.5 & $24 \%$ & $\$ 52,833.00$ & $32 \%$ \\
\hline & & & & & & & 2011 & 2.1 & $42 \%$ & $\$ 65,529.00$ & $37 \%$ & 2.5 & $27 \%$ & $\$ 58,381.00$ & $31 \%$ \\
\hline \multirow[t]{5}{*}{ Toronto } & $\begin{array}{c}\text { Portuguese } \\
\text { Presbyterian } \\
\text { Church + } \\
\text { Hepbourne } \\
\text { Lofts }\end{array}$ & Dufferin Grove & $\begin{array}{c}1992 \text { (Warzecha, } \\
2012 b)\end{array}$ & 535 & 0054.00 & $\begin{array}{l}1971- \\
2011\end{array}$ & 1971 & 3.2 & $5 \%$ & $\begin{array}{l}\$ 9,700.00 \\
\quad \text { (avg) }\end{array}$ & $33 \%$ & $\begin{array}{l}\text { no census } \\
\text { division } \\
\text { records }\end{array}$ & $\begin{array}{l}\text { no census } \\
\text { division } \\
\text { records }\end{array}$ & $\begin{array}{l}\text { no census } \\
\text { division } \\
\text { records }\end{array}$ & $\begin{array}{c}\text { no } \\
\text { census } \\
\text { divisio } \\
\mathrm{n} \\
\text { record } \\
\mathrm{s}\end{array}$ \\
\hline & & & & & & & 1976 & no census & no census & no census & $\begin{array}{c}\text { no } \\
\text { census }\end{array}$ & no census & no census & no census & $\begin{array}{c}\text { no } \\
\text { census }\end{array}$ \\
\hline & & & & & & & 1981 & 2.5 & $10 \%$ & $\$ 17,736.00$ & $35 \%$ & 2.7 & $10 \%$ & $\$ 23,301.00$ & $30 \%$ \\
\hline & & & & & & & 1986 & 2.5 & $10 \%$ & $\$ 22,199.00$ & $38 \%$ & 2.6 & $12 \%$ & $\$ 33,231.00$ & $33 \%$ \\
\hline & & & & & & & 1991 & 2.5 & $11 \%$ & $\$ 30,046.00$ & $40 \%$ & 2.6 & $15 \%$ & $\$ 43,212.00$ & $36 \%$ \\
\hline
\end{tabular}




\begin{tabular}{|c|c|c|c|c|c|c|c|c|c|c|c|c|c|c|c|}
\hline & & & & & & & 1996 & 2.4 & $14 \%$ & $\$ 33,424.00$ & $41 \%$ & 2.6 & $17 \%$ & $\$ 40,443.00$ & $35 \%$ \\
\hline & & & & & & & 2001 & 2.3 & $24 \%$ & $\$ 40,537.00$ & $42 \%$ & 2.6 & $21 \%$ & $\$ 49,345.00$ & $34 \%$ \\
\hline & & & & & & & 2006 & 2.3 & $30 \%$ & $\$ 40,725.00$ & $41 \%$ & 2.5 & $24 \%$ & $\$ 52,833.00$ & $32 \%$ \\
\hline & & & & & & & 2011 & 2.1 & $32 \%$ & $\$ 44,616.00$ & $41 \%$ & 2.5 & $27 \%$ & $\$ 58,381.00$ & $31 \%$ \\
\hline \multirow[t]{6}{*}{ Toronto } & $\begin{array}{l}\text { The Church } \\
\text { Lofts }\end{array}$ & Dufferin Grove & $\begin{array}{c}2007 \text { (City of Toronto, } \\
\text { 2007) }\end{array}$ & 535 & 0055.00 & $\begin{array}{l}1986- \\
2011\end{array}$ & 1986 & 2.9 & $12 \%$ & $\$ 25,809.00$ & $38 \%$ & 2.6 & $12 \%$ & $\$ 33,231.00$ & $33 \%$ \\
\hline & & & & & & & 1991 & 2.7 & $20 \%$ & $\$ 40,075.00$ & $44 \%$ & 2.6 & $15 \%$ & $\$ 43,212.00$ & $36 \%$ \\
\hline & & & & & & & 1996 & 2.5 & $19 \%$ & $\$ 32,108.00$ & $43 \%$ & 2.6 & $17 \%$ & $\$ 40,443.00$ & $35 \%$ \\
\hline & & & & & & & 2001 & 2.4 & $31 \%$ & $\$ 44,971.00$ & $46 \%$ & 2.6 & $21 \%$ & $\$ 49,345.00$ & $34 \%$ \\
\hline & & & & & & & 2006 & 2.2 & $38 \%$ & $\$ 43,356.00$ & $45 \%$ & 2.5 & $24 \%$ & $\$ 52,833.00$ & $32 \%$ \\
\hline & & & & & & & 2011 & 2.1 & $48 \%$ & $\$ 50,261.00$ & $45 \%$ & 2.5 & $27 \%$ & $\$ 58,381.00$ & $31 \%$ \\
\hline \multirow[t]{4}{*}{ Toronto } & $\begin{array}{l}\text { The Channel } \\
\text { Club }\end{array}$ & $\begin{array}{l}\text { College and } \\
\text { Bathurst }\end{array}$ & 1980s (Harness, 2013) & 535 & 0058.00 & $\begin{array}{l}1966- \\
2006\end{array}$ & 1966 & no census & no census & no census & $\begin{array}{c}\text { no } \\
\text { census }\end{array}$ & $\begin{array}{c}\text { no census } \\
\text { division } \\
\text { records }\end{array}$ & $\begin{array}{l}\text { no census } \\
\text { division } \\
\text { records }\end{array}$ & $\begin{array}{l}\text { no census } \\
\text { division } \\
\text { records }\end{array}$ & $\begin{array}{c}\text { no } \\
\text { census } \\
\text { divisio } \\
\mathrm{n} \\
\text { record } \\
\mathrm{s}\end{array}$ \\
\hline & & & & & & & 1971 & 4.1 & $4 \%$ & $\begin{array}{l}\$ 9,325.00 \\
\quad \text { (avg) }\end{array}$ & $35 \%$ & $\begin{array}{l}\text { no census } \\
\text { division } \\
\text { records }\end{array}$ & $\begin{array}{l}\text { no census } \\
\text { division } \\
\text { records }\end{array}$ & $\begin{array}{l}\text { no census } \\
\text { division } \\
\text { records }\end{array}$ & $\begin{array}{c}\text { no } \\
\text { census } \\
\text { divisio } \\
\mathrm{n} \\
\text { record } \\
\mathrm{s}\end{array}$ \\
\hline & & & & & & & 1976 & no census & no census & no census & $\begin{array}{c}\text { no } \\
\text { census }\end{array}$ & no census & no census & no census & $\begin{array}{c}\text { no } \\
\text { census }\end{array}$ \\
\hline & & & & & & & 1981 & 3.4 & $11 \%$ & $\$ 21,837.00$ & $34 \%$ & 2.7 & $10 \%$ & $\$ 23,301.00$ & $30 \%$ \\
\hline
\end{tabular}




\begin{tabular}{|c|c|c|c|c|c|c|c|c|c|c|c|c|c|c|c|}
\hline & & & & & & & 1986 & 3.2 & $18 \%$ & $\$ 32,312.00$ & $39 \%$ & 2.6 & $12 \%$ & $\$ 33,231.00$ & $33 \%$ \\
\hline & & & & & & & 1991 & 2.5 & $26 \%$ & $\$ 38,292.00$ & $44 \%$ & 2.6 & $15 \%$ & $\$ 43,212.00$ & $36 \%$ \\
\hline & & & & & & & 1996 & 2.3 & $29 \%$ & $\$ 35,723.00$ & $45 \%$ & 2.6 & $17 \%$ & $\$ 40,443.00$ & $35 \%$ \\
\hline & & & & & & & 2001 & 2.1 & $38 \%$ & $\$ 50,032.00$ & $47 \%$ & 2.6 & $21 \%$ & $\$ 49,345.00$ & $34 \%$ \\
\hline & & & & & & & 2006 & 2.1 & $42 \%$ & $\$ 51,057.00$ & $43 \%$ & 2.5 & $24 \%$ & $\$ 52,833.00$ & $32 \%$ \\
\hline \multirow[t]{5}{*}{ Toronto } & $\begin{array}{l}4 \text { residential } \\
\text { homes }\end{array}$ & $\begin{array}{l}\text { College and } \\
\text { Bathurst }\end{array}$ & $\begin{array}{l}\text { Conversion in } \\
\text { Progress } 2009(\mathrm{City} \text { of } \\
\text { Toronto, 2009b) }\end{array}$ & 535 & 0058.00 & $\begin{array}{l}1991- \\
2011\end{array}$ & 1991 & 2.5 & $26 \%$ & $\$ 38,292.00$ & $44 \%$ & 2.6 & $15 \%$ & $\$ 43,212.00$ & $36 \%$ \\
\hline & & & & & & & 1996 & 2.3 & $29 \%$ & $\$ 35,723.00$ & $45 \%$ & 2.6 & $17 \%$ & $\$ 40,443.00$ & $35 \%$ \\
\hline & & & & & & & 2001 & 2.1 & $38 \%$ & $\$ 50,032.00$ & $47 \%$ & 2.6 & $21 \%$ & $\$ 49,345.00$ & $34 \%$ \\
\hline & & & & & & & 2006 & 2.1 & $42 \%$ & $\$ 51,057.00$ & $43 \%$ & 2.5 & $24 \%$ & $\$ 52,833.00$ & $32 \%$ \\
\hline & & & & & & & 2011 & 2.1 & $49 \%$ & $\$ 58,182.00$ & $42 \%$ & 2.5 & $27 \%$ & $\$ 58,381.00$ & $31 \%$ \\
\hline \multirow[t]{7}{*}{ Toronto } & $\begin{array}{c}\text { The Glebe } \\
\text { Lofts }\end{array}$ & North Riverdale & $\begin{array}{l}2001 \text { (City of Toronto, } \\
\text { 2001b) }\end{array}$ & 535 & 0071.00 & $\begin{array}{l}1981- \\
2011\end{array}$ & 1981 & 3.2 & $11 \%$ & $\$ 20,845.00$ & $36 \%$ & 2.7 & $10 \%$ & $\$ 23,301.00$ & $30 \%$ \\
\hline & & & & & & & 1986 & 2.8 & $20 \%$ & $\$ 34,723.00$ & $41 \%$ & 2.6 & $12 \%$ & $\$ 33,231.00$ & $33 \%$ \\
\hline & & & & & & & 1991 & 2.7 & $22 \%$ & $\$ 53,841.00$ & $42 \%$ & 2.6 & $15 \%$ & $\$ 43,212.00$ & $36 \%$ \\
\hline & & & & & & & 1996 & 2.5 & $32 \%$ & $\$ 54,010.00$ & $41 \%$ & 2.6 & $17 \%$ & $\$ 40,443.00$ & $35 \%$ \\
\hline & & & & & & & 2001 & 2.5 & $32 \%$ & $\$ 66,747.00$ & $38 \%$ & 2.6 & $21 \%$ & $\$ 49,345.00$ & $34 \%$ \\
\hline & & & & & & & 2006 & 2.5 & $40 \%$ & $\$ 78,738.00$ & $33 \%$ & 2.5 & $24 \%$ & $\$ 52,833.00$ & $32 \%$ \\
\hline & & & & & & & 2011 & 2.4 & $42 \%$ & $\$ 90,598.00$ & $27 \%$ & 2.5 & $27 \%$ & $\$ 58,381.00$ & $31 \%$ \\
\hline
\end{tabular}




\begin{tabular}{|c|c|c|c|c|c|c|c|c|c|c|c|c|c|c|c|}
\hline Toronto & $\begin{array}{l}\text { The Swanwick } \\
\text { Heritage Loft }\end{array}$ & $\begin{array}{l}\text { The North } \\
\text { Beaches }\end{array}$ & $\begin{array}{c}2007-2008 \text { (City of } \\
\text { Toronto, 2008a) }\end{array}$ & 535 & 0078.00 & $\begin{array}{l}1986- \\
2011\end{array}$ & 1986 & 2.4 & $11 \%$ & $\$ 30,999.00$ & $38 \%$ & 2.6 & $12 \%$ & $\$ 33,231.00$ & $33 \%$ \\
\hline & & & & & & & 1991 & 2.2 & $15 \%$ & $\$ 42,999.00$ & $43 \%$ & 2.6 & $15 \%$ & $\$ 43,212.00$ & $36 \%$ \\
\hline & & & & & & & 1996 & 2.2 & $19 \%$ & $\$ 40,288.00$ & $42 \%$ & 2.6 & $17 \%$ & $\$ 40,443.00$ & $35 \%$ \\
\hline & & & & & & & 2001 & 2.1 & $22 \%$ & $\$ 49,372.00$ & $39 \%$ & 2.6 & $21 \%$ & $\$ 49,345.00$ & $34 \%$ \\
\hline & & & & & & & 2006 & 2.1 & $27 \%$ & $\$ 57,906.00$ & $34 \%$ & 2.5 & $24 \%$ & $\$ 52,833.00$ & $32 \%$ \\
\hline & & & & & & & 2011 & 2.1 & $32 \%$ & $\$ 63,630.00$ & $31 \%$ & 2.5 & $27 \%$ & $\$ 58,381.00$ & $31 \%$ \\
\hline Toronto & 36Hazelton & Yorkville & $\begin{array}{c}2006 \text { (City of Toronto, } \\
\text { 2009a) }\end{array}$ & 535 & 0089.00 & $\begin{array}{l}1986- \\
2011\end{array}$ & 1986 & 1.7 & $31 \%$ & $\$ 40,454.00$ & $38 \%$ & 2.6 & $12 \%$ & $\$ 33,231.00$ & $33 \%$ \\
\hline & & & & & & & 1991 & 1.7 & $52 \%$ & $\$ 64,066.00$ & $39 \%$ & 2.6 & $15 \%$ & $\$ 43,212.00$ & $36 \%$ \\
\hline & & & & & & & 1996 & 1.6 & $47 \%$ & $\$ 65,988.00$ & $37 \%$ & 2.6 & $17 \%$ & $\$ 40,443.00$ & $35 \%$ \\
\hline & & & & & & & 2001 & 1.6 & $55 \%$ & $\$ 60,117.00$ & $36 \%$ & 2.6 & $21 \%$ & $\$ 49,345.00$ & $34 \%$ \\
\hline & & & & & & & 2006 & 1.6 & $60 \%$ & $\$ 70,219.00$ & $37 \%$ & 2.5 & $24 \%$ & $\$ 52,833.00$ & $32 \%$ \\
\hline & & & & & & & 2011 & 1.6 & $56 \%$ & $\$ 88,242.00$ & $34 \%$ & 2.5 & $27 \%$ & $\$ 58,381.00$ & $31 \%$ \\
\hline Toronto & $\begin{array}{l}\text { Macpherson } \\
\text { Church Lofts }\end{array}$ & Yorkville & $\begin{array}{l}\text { Completed } 1990 \\
\text { (Lynch, 2013) }\end{array}$ & 535 & 0090.00 & $\begin{array}{l}1966- \\
2006\end{array}$ & 1966 & no census & no census & no census & $\begin{array}{c}\text { no } \\
\text { census }\end{array}$ & $\begin{array}{l}\text { no census } \\
\text { division } \\
\text { records }\end{array}$ & $\begin{array}{l}\text { no census } \\
\text { division } \\
\text { records }\end{array}$ & $\begin{array}{l}\text { no census } \\
\text { division } \\
\text { records }\end{array}$ & $\begin{array}{l}\text { no } \\
\text { census } \\
\text { divisio } \\
n \\
\text { record } \\
\mathrm{s}\end{array}$ \\
\hline & & & & & & & 1971 & 2.3 & $16 \%$ & $\begin{array}{l}\$ 11,405.00 \\
\quad \text { (avg) }\end{array}$ & $40 \%$ & $\begin{array}{c}\text { no census } \\
\text { division } \\
\text { records }\end{array}$ & $\begin{array}{c}\text { no census } \\
\text { division } \\
\text { records }\end{array}$ & $\begin{array}{l}\text { no census } \\
\text { division } \\
\text { records }\end{array}$ & $\begin{array}{l}\text { no } \\
\text { census } \\
\text { divisio } \\
n \\
\text { record } \\
\quad \mathrm{s}\end{array}$ \\
\hline
\end{tabular}




\begin{tabular}{|c|c|c|c|c|c|c|c|c|c|c|c|c|c|c|}
\hline & & & & & & 1976 & no census & no census & no census & $\begin{array}{c}\text { no } \\
\text { census }\end{array}$ & no census & no census & no census & $\begin{array}{c}\text { no } \\
\text { census }\end{array}$ \\
\hline & & & & & & 1981 & 1.7 & $30 \%$ & $\$ 21,244.00$ & $43 \%$ & 2.7 & $10 \%$ & $\$ 23,301.00$ & $30 \%$ \\
\hline & & & & & & 1986 & 1.8 & $31 \%$ & $\$ 35,908.00$ & $40 \%$ & 2.6 & $12 \%$ & $\$ 33,231.00$ & $33 \%$ \\
\hline & & & & & & 1991 & 1.7 & $41 \%$ & $\$ 50,051.00$ & $38 \%$ & 2.6 & $15 \%$ & $\$ 43,212.00$ & $36 \%$ \\
\hline & & & & & & 1996 & 1.7 & $45 \%$ & $\$ 48,976.00$ & $44 \%$ & 2.6 & $17 \%$ & $\$ 40,443.00$ & $35 \%$ \\
\hline & & & & & & 2001 & 1.6 & $50 \%$ & $\$ 60,198.00$ & $37 \%$ & 2.6 & $21 \%$ & $\$ 49,345.00$ & $34 \%$ \\
\hline & & & & & & 2006 & 1.6 & $55 \%$ & $\$ 70,641.00$ & $35 \%$ & 2.5 & $24 \%$ & $\$ 52,833.00$ & $32 \%$ \\
\hline \multirow[t]{5}{*}{ Toronto } & $\begin{array}{c}\text { The } \\
\text { Schoolhouse }\end{array}$ & The Annex & $\begin{array}{c}\text { Conversion in } \\
\text { Progress } 2010 \text { (Kulig, } \\
\text { 2010) }\end{array}$ & 535 & 0092.00 & 1991 & 1.8 & $40 \%$ & $\$ 33,451.00$ & $51 \%$ & 2.6 & $15 \%$ & $\$ 43,212.00$ & $36 \%$ \\
\hline & & & & & & 1996 & 1.8 & $44 \%$ & $\$ 33,987.00$ & $52 \%$ & 2.6 & $17 \%$ & $\$ 40,443.00$ & $35 \%$ \\
\hline & & & & & & 2001 & 1.8 & $52 \%$ & $\$ 44,818.00$ & $49 \%$ & 2.6 & $21 \%$ & $\$ 49,345.00$ & $34 \%$ \\
\hline & & & & & & 2006 & 1.8 & $56 \%$ & $\$ 47,811.00$ & $45 \%$ & 2.5 & $24 \%$ & $\$ 52,833.00$ & $32 \%$ \\
\hline & & & & & & 2011 & 1.8 & $57 \%$ & $\$ 47,526.00$ & $45 \%$ & 2.5 & $27 \%$ & $\$ 58,381.00$ & $31 \%$ \\
\hline \multirow[t]{5}{*}{ Toronto } & The Loretto & The Annex & $\begin{array}{l}\text { Completed 2007 } \\
\text { (Kulig, 2010) }\end{array}$ & 535 & 0092.00 & 1991 & 1.8 & $40 \%$ & $\$ 33,451.00$ & $51 \%$ & 2.6 & $15 \%$ & $\$ 43,212.00$ & $36 \%$ \\
\hline & & & & & & 1996 & 1.8 & $44 \%$ & $\$ 33,987.00$ & $52 \%$ & 2.6 & $17 \%$ & $\$ 40,443.00$ & $35 \%$ \\
\hline & & & & & & 2001 & 1.8 & $52 \%$ & $\$ 44,818.00$ & $49 \%$ & 2.6 & $21 \%$ & $\$ 49,345.00$ & $34 \%$ \\
\hline & & & & & & 2006 & 1.8 & $56 \%$ & $\$ 47,811.00$ & $45 \%$ & 2.5 & $24 \%$ & $\$ 52,833.00$ & $32 \%$ \\
\hline & & & & & & 2011 & 1.8 & $57 \%$ & $\$ 47,526.00$ & $45 \%$ & 2.5 & $27 \%$ & $\$ 58,381.00$ & $31 \%$ \\
\hline
\end{tabular}




\begin{tabular}{|c|c|c|c|c|c|c|c|c|c|c|c|c|c|c|c|}
\hline Toronto & West 40 & Dovercourt Park & $\begin{array}{l}2003-2004 \text { (City of } \\
\text { Toronto, 2012b) }\end{array}$ & 535 & 0096.00 & $\begin{array}{l}1981- \\
2011\end{array}$ & 1981 & 3.6 & $3 \%$ & $\$ 19,855.00$ & $28 \%$ & 2.7 & $10 \%$ & $\$ 23,301.00$ & $30 \%$ \\
\hline & & & & & & & 1986 & 3.4 & $6 \%$ & $\$ 29,725.00$ & $32 \%$ & 2.6 & $12 \%$ & $\$ 33,231.00$ & $33 \%$ \\
\hline & & & & & & & 1991 & 3.2 & $10 \%$ & $\$ 39,163.00$ & $38 \%$ & 2.6 & $15 \%$ & $\$ 43,212.00$ & $36 \%$ \\
\hline & & & & & & & 1996 & 3 & $12 \%$ & $\$ 35,935.00$ & $38 \%$ & 2.6 & $17 \%$ & $\$ 40,443.00$ & $35 \%$ \\
\hline & & & & & & & 2001 & 2.9 & $18 \%$ & $\$ 50,953.00$ & $38 \%$ & 2.6 & $21 \%$ & $\$ 49,345.00$ & $34 \%$ \\
\hline & & & & & & & 2006 & 2.6 & $25 \%$ & $\$ 55,122.00$ & $38 \%$ & 2.5 & $24 \%$ & $\$ 52,833.00$ & $32 \%$ \\
\hline & & & & & & & 2011 & 2.5 & $27 \%$ & $\$ 61,022.00$ & $36 \%$ & 2.5 & $27 \%$ & $\$ 58,381.00$ & $31 \%$ \\
\hline \multirow[t]{5}{*}{ Toronto } & $\begin{array}{l}\text { Sanctuary } \\
\text { Lofts }\end{array}$ & Dovercourt Park & $\begin{array}{l}2012 \text { (City of Toronto, } \\
\text { 2012d) }\end{array}$ & 535 & 0096.00 & $\begin{array}{l}1991- \\
2011\end{array}$ & 1991 & 3.2 & $10 \%$ & $\$ 39,163.00$ & $38 \%$ & 2.6 & $15 \%$ & $\$ 43,212.00$ & $36 \%$ \\
\hline & & & & & & & 1996 & 3 & $12 \%$ & $\$ 35,935.00$ & $38 \%$ & 2.6 & $17 \%$ & $\$ 40,443.00$ & $35 \%$ \\
\hline & & & & & & & 2001 & 2.9 & $18 \%$ & $\$ 50,953.00$ & $38 \%$ & 2.6 & $21 \%$ & $\$ 49,345.00$ & $34 \%$ \\
\hline & & & & & & & 2006 & 2.6 & $25 \%$ & $\$ 55,122.00$ & $38 \%$ & 2.5 & $24 \%$ & $\$ 52,833.00$ & $32 \%$ \\
\hline & & & & & & & 2011 & 2.5 & $27 \%$ & $\$ 61,022.00$ & $36 \%$ & 2.5 & $27 \%$ & $\$ 58,381.00$ & $31 \%$ \\
\hline \multirow[t]{5}{*}{ Toronto } & Union Lofts & Junction Triangle & $\begin{array}{c}2012 \text { (City of Toronto, } \\
2012 \mathrm{c} \text { ) }\end{array}$ & 535 & 0098.00 & $\begin{array}{l}1991- \\
2011\end{array}$ & 1991 & 3 & $4 \%$ & $\$ 29,855.00$ & $36 \%$ & 2.6 & $15 \%$ & $\$ 43,212.00$ & $36 \%$ \\
\hline & & & & & & & 1996 & 2.9 & $7 \%$ & $\$ 29,619.00$ & $36 \%$ & 2.6 & $17 \%$ & $\$ 40,443.00$ & $35 \%$ \\
\hline & & & & & & & 2001 & 2.8 & $10 \%$ & $\$ 37,827.00$ & $37 \%$ & 2.6 & $21 \%$ & $\$ 49,345.00$ & $34 \%$ \\
\hline & & & & & & & 2006 & 2.5 & $18 \%$ & $\$ 39,598.00$ & $36 \%$ & 2.5 & $24 \%$ & $\$ 52,833.00$ & $32 \%$ \\
\hline & & & & & & & 2011 & 2.4 & $20 \%$ & $\$ 53,666.00$ & $37 \%$ & 2.5 & $27 \%$ & $\$ 58,381.00$ & $31 \%$ \\
\hline
\end{tabular}




\begin{tabular}{|c|c|c|c|c|c|c|c|c|c|c|c|c|c|c|c|}
\hline Toronto & Park Lofts & The Junction & $\begin{array}{c}2010 \text { (City of Toronto, } \\
\text { 2010b) }\end{array}$ & 535 & 0101.00 & $\begin{array}{l}1991- \\
2011\end{array}$ & 1991 & 2.4 & $18 \%$ & $\$ 42,327.00$ & $45 \%$ & 2.6 & $15 \%$ & $\$ 43,212.00$ & $36 \%$ \\
\hline & & & & & & & 1996 & 2.4 & $22 \%$ & $\$ 36,586.00$ & $46 \%$ & 2.6 & $17 \%$ & $\$ 40,443.00$ & $35 \%$ \\
\hline & & & & & & & 2001 & 2.3 & $27 \%$ & $\$ 49,951.00$ & $45 \%$ & 2.6 & $21 \%$ & $\$ 49,345.00$ & $34 \%$ \\
\hline & & & & & & & 2006 & 2.2 & $36 \%$ & $\$ 50,115.00$ & $44 \%$ & 2.5 & $24 \%$ & $\$ 52,833.00$ & $32 \%$ \\
\hline & & & & & & & 2011 & 2.1 & $36 \%$ & $\$ 64,041.00$ & $45 \%$ & 2.5 & $27 \%$ & $\$ 58,381.00$ & $31 \%$ \\
\hline \multirow[t]{6}{*}{ Toronto } & Victoria Lofts & The Junction & $\begin{array}{c}2008 \text { (City of Toronto, } \\
\text { 2008b) }\end{array}$ & 535 & 0101.00 & $\begin{array}{l}1986- \\
2011\end{array}$ & 1986 & 2.6 & $15 \%$ & $\$ 31,599.00$ & $40 \%$ & 2.6 & $12 \%$ & $\$ 33,231.00$ & $33 \%$ \\
\hline & & & & & & & 1991 & 2.4 & $18 \%$ & $\$ 42,327.00$ & $45 \%$ & 2.6 & $15 \%$ & $\$ 43,212.00$ & $36 \%$ \\
\hline & & & & & & & 1996 & 2.4 & $22 \%$ & $\$ 36,586.00$ & $46 \%$ & 2.6 & $17 \%$ & $\$ 40,443.00$ & $35 \%$ \\
\hline & & & & & & & 2001 & 2.3 & $27 \%$ & $\$ 49,951.00$ & $45 \%$ & 2.6 & $21 \%$ & $\$ 49,345.00$ & $34 \%$ \\
\hline & & & & & & & 2006 & 2.2 & $36 \%$ & $\$ 50,115.00$ & $44 \%$ & 2.5 & $24 \%$ & $\$ 52,833.00$ & $32 \%$ \\
\hline & & & & & & & 2011 & 2.1 & $36 \%$ & $\$ 64,041.00$ & $45 \%$ & 2.5 & $27 \%$ & $\$ 58,381.00$ & $31 \%$ \\
\hline \multirow[t]{6}{*}{ Toronto } & $\begin{array}{c}70 \text { High Park } \\
\text { Ave } \\
\text { Condominiums }\end{array}$ & High Park & $\begin{array}{l}2001 \text { (City of Toronto, } \\
\text { 2001a) }\end{array}$ & 535 & 0102.02 & $\begin{array}{l}1981- \\
2011\end{array}$ & 1981 & 1.6 & $24 \%$ & $\$ 20,002.00$ & $46 \%$ & 2.7 & $10 \%$ & $\$ 23,301.00$ & $30 \%$ \\
\hline & & & & & & & 1986 & 1.6 & $27 \%$ & $\$ 27,835.00$ & $49 \%$ & 2.6 & $12 \%$ & $\$ 33,231.00$ & $33 \%$ \\
\hline & & & & & & & 1991 & 1.7 & $27 \%$ & $\$ 36,017.00$ & $51 \%$ & 2.6 & $15 \%$ & $\$ 43,212.00$ & $36 \%$ \\
\hline & & & & & & & 1996 & 1.9 & $30 \%$ & $\$ 35,294.00$ & $48 \%$ & 2.6 & $17 \%$ & $\$ 40,443.00$ & $35 \%$ \\
\hline & & & & & & & 2001 & no census & no census & no census & $\begin{array}{l}\text { no } \\
\text { census }\end{array}$ & 2.6 & $21 \%$ & $\$ 49,345.00$ & $34 \%$ \\
\hline & & & & & & & 2006 & 1.7 & $48 \%$ & $\$ 42,487.00$ & $47 \%$ & 2.5 & $24 \%$ & $\$ 52,833.00$ & $32 \%$ \\
\hline
\end{tabular}




\begin{tabular}{|c|c|c|c|c|c|c|c|c|c|c|c|c|c|c|c|}
\hline & & & & & & & 2011 & 1.7 & $43 \%$ & $\$ 51,131.00$ & $46 \%$ & 2.5 & $27 \%$ & $\$ 58,381.00$ & $31 \%$ \\
\hline \multirow[t]{9}{*}{ Toronto } & $\begin{array}{l}\text { Woodlawn } \\
\text { Church Loft }\end{array}$ & Summerhill & $\begin{array}{l}\text { Completed 1990 } \\
\text { (Warzecha, 2012a) }\end{array}$ & 535 & 0120.00 & $\begin{array}{l}1971- \\
2011\end{array}$ & 1971 & 2.6 & $14 \%$ & $\begin{array}{l}\$ 11,970.00 \\
\quad \text { (avg) }\end{array}$ & $34 \%$ & $\begin{array}{c}\text { no census } \\
\text { division } \\
\text { records }\end{array}$ & $\begin{array}{l}\text { no census } \\
\text { division } \\
\text { records }\end{array}$ & $\begin{array}{l}\text { no census } \\
\text { division } \\
\text { records }\end{array}$ & $\begin{array}{c}\text { no } \\
\text { census } \\
\text { divisio } \\
\mathrm{n} \\
\text { record } \\
\quad \mathrm{s}\end{array}$ \\
\hline & & & & & & & 1976 & no census & no census & no census & $\begin{array}{c}\text { no } \\
\text { census }\end{array}$ & no census & no census & no census & $\begin{array}{c}\text { no } \\
\text { census }\end{array}$ \\
\hline & & & & & & & 1981 & 2.1 & $35 \%$ & $\$ 30,307.00$ & $40 \%$ & 2.7 & $10 \%$ & $\$ 23,301.00$ & $30 \%$ \\
\hline & & & & & & & 1986 & 2.2 & $40 \%$ & $\$ 58,099.00$ & $38 \%$ & 2.6 & $12 \%$ & $\$ 33,231.00$ & $33 \%$ \\
\hline & & & & & & & 1991 & 2 & $44 \%$ & $\$ 75,909.00$ & $37 \%$ & 2.6 & $15 \%$ & $\$ 43,212.00$ & $36 \%$ \\
\hline & & & & & & & 1996 & 2 & $51 \%$ & $\$ 68,893.00$ & $33 \%$ & 2.6 & $17 \%$ & $\$ 40,443.00$ & $35 \%$ \\
\hline & & & & & & & 2001 & 2 & $43 \%$ & $\$ 98,155.00$ & $31 \%$ & 2.6 & $21 \%$ & $\$ 49,345.00$ & $34 \%$ \\
\hline & & & & & & & 2006 & 2.1 & $56 \%$ & $\$ 91,944.00$ & $31 \%$ & 2.5 & $24 \%$ & $\$ 52,833.00$ & $32 \%$ \\
\hline & & & & & & & 2011 & 2 & $65 \%$ & $\$ 109,445.00$ & $28 \%$ & 2.5 & $27 \%$ & $\$ 58,381.00$ & $31 \%$ \\
\hline \multirow[t]{5}{*}{ Toronto } & Blue Diamond & Deer Park & $\begin{array}{c}2012 \text { (City of Toronto, } \\
\text { 2012a) }\end{array}$ & 535 & 0121.00 & $\begin{array}{l}1991- \\
2011\end{array}$ & 1991 & 1.7 & $48 \%$ & $\$ 67,586.00$ & $37 \%$ & 2.6 & $15 \%$ & $\$ 43,212.00$ & $36 \%$ \\
\hline & & & & & & & 1996 & 1.7 & $46 \%$ & $\$ 69,491.00$ & $34 \%$ & 2.6 & $17 \%$ & $\$ 40,443.00$ & $35 \%$ \\
\hline & & & & & & & 2001 & 1.8 & $50 \%$ & $\$ 100,366.00$ & $28 \%$ & 2.6 & $21 \%$ & $\$ 49,345.00$ & $34 \%$ \\
\hline & & & & & & & 2006 & 1.7 & $59 \%$ & $\$ 87,206.00$ & $27 \%$ & 2.5 & $24 \%$ & $\$ 52,833.00$ & $32 \%$ \\
\hline & & & & & & & 2011 & 1.8 & $58 \%$ & $\$ 105,465.00$ & $25 \%$ & 2.5 & $27 \%$ & $\$ 58,381.00$ & $31 \%$ \\
\hline Toronto & $\begin{array}{l}\text { St. George on } \\
\text { Sheldrake }\end{array}$ & North Toronto & $\begin{array}{l}\text { Completed 2001 } \\
\text { (Lynch, 2013) }\end{array}$ & 535 & 0137.00 & $\begin{array}{l}1981- \\
2011\end{array}$ & 1981 & 2 & $22 \%$ & $\$ 22,122.00$ & $37 \%$ & 2.7 & $10 \%$ & $\$ 23,301.00$ & $30 \%$ \\
\hline
\end{tabular}




\begin{tabular}{|c|c|c|c|c|c|c|c|c|c|c|c|c|c|c|c|}
\hline & & & & & & & 1986 & 1.9 & $29 \%$ & $\$ 32,670.00$ & $39 \%$ & 2.6 & $12 \%$ & $\$ 33,231.00$ & $33 \%$ \\
\hline & & & & & & & 1991 & 1.8 & $31 \%$ & $\$ 47,009.00$ & $40 \%$ & 2.6 & $15 \%$ & $\$ 43,212.00$ & $36 \%$ \\
\hline & & & & & & & 1996 & 1.9 & $38 \%$ & $\$ 47,766.00$ & $40 \%$ & 2.6 & $17 \%$ & $\$ 40,443.00$ & $35 \%$ \\
\hline & & & & & & & 2001 & 1.9 & $42 \%$ & $\$ 55,292.00$ & $39 \%$ & 2.6 & $21 \%$ & $\$ 49,345.00$ & $34 \%$ \\
\hline & & & & & & & 2006 & 1.9 & $51 \%$ & $\$ 63,422.00$ & $37 \%$ & 2.5 & $24 \%$ & $\$ 52,833.00$ & $32 \%$ \\
\hline & & & & & & & 2011 & 1.9 & $47 \%$ & $\$ 65,309.00$ & $34 \%$ & 2.5 & $27 \%$ & $\$ 58,381.00$ & $31 \%$ \\
\hline \multirow[t]{6}{*}{ Ottawa } & $\begin{array}{l}\text { École Sacré- } \\
\text { Coeur }\end{array}$ & Hintonburg & $\begin{array}{l}\text { Completed } 2009 \\
\text { (Ottawa Condo } \\
\text { Network, 2014d) }\end{array}$ & 505 & 0043.00 & $\begin{array}{l}1986- \\
2011\end{array}$ & 1986 & 2.2 & $16 \%$ & $\$ 27,674.00$ & $39 \%$ & 2.6 & $16 \%$ & $\$ 37,994.00$ & $35 \%$ \\
\hline & & & & & & & 1991 & 2 & $21 \%$ & $\$ 35,892.00$ & $46 \%$ & 2.5 & $18 \%$ & $\$ 49,407.00$ & $36 \%$ \\
\hline & & & & & & & 1996 & 2.1 & $22 \%$ & $\$ 34,762.00$ & $46 \%$ & 2.6 & $20 \%$ & $\$ 50,804.00$ & $34 \%$ \\
\hline & & & & & & & 2001 & 2 & $24 \%$ & $\$ 43,333.00$ & $45 \%$ & 2.5 & $23 \%$ & $\$ 62,130.00$ & $33 \%$ \\
\hline & & & & & & & 2006 & 2 & $35 \%$ & $\$ 50,894.00$ & $41 \%$ & 2.5 & $26 \%$ & $\$ 69,743.00$ & $29 \%$ \\
\hline & & & & & & & 2011 & 1.9 & $38 \%$ & $\$ 60,312.00$ & $40 \%$ & 2.5 & $29 \%$ & $\$ 79,634.00$ & $28 \%$ \\
\hline \multirow[t]{5}{*}{ Ottawa } & $\begin{array}{c}\text { Yard and } \\
\text { Station Lofts }\end{array}$ & Hintonburg & 2013 (Mills, 2014) & 505 & 0046.00 & $\begin{array}{l}1991- \\
2011\end{array}$ & 1991 & 1.7 & $17 \%$ & $\$ 27,209.00$ & $43 \%$ & 2.5 & $18 \%$ & $\$ 49,407.00$ & $36 \%$ \\
\hline & & & & & & & 1996 & 1.8 & $18 \%$ & $\$ 23,866.00$ & $42 \%$ & 2.6 & $20 \%$ & $\$ 50,804.00$ & $34 \%$ \\
\hline & & & & & & & 2001 & 1.8 & $22 \%$ & $\$ 34,215.00$ & $40 \%$ & 2.5 & $23 \%$ & $\$ 62,130.00$ & $33 \%$ \\
\hline & & & & & & & 2006 & 1.7 & $29 \%$ & $\$ 35,902.00$ & $38 \%$ & 2.5 & $26 \%$ & $\$ 69,743.00$ & $29 \%$ \\
\hline & & & & & & & 2011 & 1.6 & $31 \%$ & $\$ 46,132.00$ & $37 \%$ & 2.5 & $29 \%$ & $\$ 79,634.00$ & $28 \%$ \\
\hline
\end{tabular}




\begin{tabular}{|c|c|c|c|c|c|c|c|c|c|c|c|c|c|c|c|}
\hline Ottawa & École Guigues & Byward Market & $\begin{array}{l}\text { Completed } 1995 \\
\text { (Ottawa Condo } \\
\text { Network, 2014a) }\end{array}$ & 505 & 0054.00 & $\begin{array}{l}1976- \\
2011\end{array}$ & 1976 & no census & no census & no census & $\begin{array}{c}\text { no } \\
\text { census }\end{array}$ & no census & no census & no census & $\begin{array}{c}\text { no } \\
\text { census }\end{array}$ \\
\hline & & & & & & & 1981 & 1.8 & $12 \%$ & $\$ 10,568.00$ & $35 \%$ & 2.7 & $14 \%$ & $\$ 24,860.00$ & $32 \%$ \\
\hline & & & & & & & 1986 & 1.7 & $21 \%$ & $\$ 18,837.00$ & $41 \%$ & 2.6 & $16 \%$ & $\$ 37,994.00$ & $35 \%$ \\
\hline & & & & & & & 1991 & 1.6 & $26 \%$ & $\$ 29,253.00$ & $45 \%$ & 2.5 & $18 \%$ & $\$ 49,407.00$ & $36 \%$ \\
\hline & & & & & & & 1996 & 1.6 & $28 \%$ & $\$ 29,947.00$ & $47 \%$ & 2.6 & $20 \%$ & $\$ 50,804.00$ & $34 \%$ \\
\hline & & & & & & & 2001 & 1.5 & no record & no record & $46 \%$ & 2.5 & $23 \%$ & $\$ 62,130.00$ & $33 \%$ \\
\hline & & & & & & & 2006 & 1.5 & $43 \%$ & $\$ 51,580.00$ & $44 \%$ & 2.5 & $26 \%$ & $\$ 69,743.00$ & $29 \%$ \\
\hline & & & & & & & 2011 & 1.5 & $44 \%$ & $\$ 55,338.00$ & $42 \%$ & 2.5 & $29 \%$ & $\$ 79,634.00$ & $28 \%$ \\
\hline Ottawa & $\begin{array}{l}\text { Schoolhouse } \\
\text { Square }\end{array}$ & New Edinburgh & $\begin{array}{l}\text { Completed } 1997 \\
\text { (Ottawa Condo } \\
\text { Network, 2014b) }\end{array}$ & 505 & 0057.00 & $\begin{array}{l}1976- \\
2011\end{array}$ & 1976 & no census & no census & no census & $\begin{array}{c}\text { no } \\
\text { census }\end{array}$ & no census & no census & no census & $\begin{array}{c}\text { no } \\
\text { census }\end{array}$ \\
\hline & & & & & & & 1981 & 2.5 & $10 \%$ & $\$ 19,961.00$ & $27 \%$ & 2.7 & $14 \%$ & $\$ 24,860.00$ & $32 \%$ \\
\hline & & & & & & & 1986 & 2.3 & $18 \%$ & $\$ 29,899.00$ & $31 \%$ & 2.6 & $16 \%$ & $\$ 37,994.00$ & $35 \%$ \\
\hline & & & & & & & 1991 & 2 & $25 \%$ & $\$ 42,857.00$ & $35 \%$ & 2.5 & $18 \%$ & $\$ 49,407.00$ & $36 \%$ \\
\hline & & & & & & & 1996 & 2 & $23 \%$ & $\$ 48,228.00$ & $34 \%$ & 2.6 & $20 \%$ & $\$ 50,804.00$ & $34 \%$ \\
\hline & & & & & & & 2001 & 2 & $31 \%$ & $\$ 63,064.00$ & $30 \%$ & 2.5 & $23 \%$ & $\$ 62,130.00$ & $33 \%$ \\
\hline & & & & & & & 2006 & 1.9 & $43 \%$ & $\$ 65,015.00$ & $31 \%$ & 2.5 & $26 \%$ & $\$ 69,743.00$ & $29 \%$ \\
\hline & & & & & & & 2011 & 2 & $50 \%$ & $\$ 66,101.00$ & $31 \%$ & 2.5 & $29 \%$ & $\$ 79,634.00$ & $28 \%$ \\
\hline Ottawa & Archive Square & New Edinburgh & 1999 (Ngoh) & 505 & 0058.00 & $\begin{array}{l}1981- \\
2011\end{array}$ & 1981 & 2.1 & $28 \%$ & $\$ 25,458.00$ & $30 \%$ & 2.7 & $14 \%$ & $\$ 24,860.00$ & $32 \%$ \\
\hline
\end{tabular}




\begin{tabular}{|c|c|c|c|c|c|c|c|c|c|c|c|c|c|c|c|}
\hline & & & & & & & 1986 & 2.1 & $35 \%$ & $\$ 48,224.00$ & $32 \%$ & 2.6 & $16 \%$ & $\$ 37,994.00$ & $35 \%$ \\
\hline & & & & & & & 1991 & 2 & $40 \%$ & $\$ 56,732.00$ & $31 \%$ & 2.5 & $18 \%$ & $\$ 49,407.00$ & $36 \%$ \\
\hline & & & & & & & 1996 & 2 & $43 \%$ & $\$ 63,044.00$ & $29 \%$ & 2.6 & $20 \%$ & $\$ 50,804.00$ & $34 \%$ \\
\hline & & & & & & & 2001 & 2 & $50 \%$ & $\$ 76,299.00$ & $28 \%$ & 2.5 & $23 \%$ & $\$ 62,130.00$ & $33 \%$ \\
\hline & & & & & & & 2006 & 2 & $55 \%$ & $\$ 86,201.00$ & $26 \%$ & 2.5 & $26 \%$ & $\$ 69,743.00$ & $29 \%$ \\
\hline & & & & & & & 2011 & 2 & $56 \%$ & $\$ 90,125.00$ & $23 \%$ & 2.5 & $29 \%$ & $\$ 79,634.00$ & $28 \%$ \\
\hline Ottawa & $\begin{array}{l}\text { Les Lofts du } \\
\text { Montfort }\end{array}$ & Vanier & $\begin{array}{l}\text { Completed } 1998 \\
\text { (Ottawa Condo } \\
\text { Network, 2014c) }\end{array}$ & 505 & 0102.00 & $\begin{array}{l}1971- \\
2011\end{array}$ & 1971 & 3.3 & $4 \%$ & $\begin{array}{l}\$ 8,835.00 \\
\quad \text { (avg) }\end{array}$ & $26 \%$ & $\begin{array}{l}\text { no census } \\
\text { division } \\
\text { records }\end{array}$ & $\begin{array}{l}\text { no census } \\
\text { division } \\
\text { records }\end{array}$ & $\begin{array}{l}\text { no census } \\
\text { division } \\
\text { records }\end{array}$ & $\begin{array}{l}\text { no } \\
\text { census } \\
\text { divisio } \\
\text { n } \\
\text { record } \\
\text { s }\end{array}$ \\
\hline & & & & & & & 1976 & no census & no census & no census & $\begin{array}{c}\text { no } \\
\text { census }\end{array}$ & no census & no census & no census & $\begin{array}{l}\text { no } \\
\text { census }\end{array}$ \\
\hline & & & & & & & 1981 & 2.2 & $5 \%$ & $\$ 14,778.00$ & $29 \%$ & 2.7 & $14 \%$ & $\$ 24,860.00$ & $32 \%$ \\
\hline & & & & & & & 1986 & 2.1 & $9 \%$ & $\$ 22,388.00$ & $34 \%$ & 2.6 & $16 \%$ & $\$ 37,994.00$ & $35 \%$ \\
\hline & & & & & & & 1991 & 1.8 & $12 \%$ & $\$ 28,985.00$ & $35 \%$ & 2.5 & $18 \%$ & $\$ 49,407.00$ & $36 \%$ \\
\hline & & & & & & & 1996 & 1.9 & $10 \%$ & $\$ 28,022.00$ & $32 \%$ & 2.6 & $20 \%$ & $\$ 50,804.00$ & $34 \%$ \\
\hline & & & & & & & 2001 & 1.8 & $8 \%$ & $\$ 30,677.00$ & $29 \%$ & 2.5 & $23 \%$ & $\$ 62,130.00$ & $33 \%$ \\
\hline & & & & & & & 2006 & 1.8 & $16 \%$ & $\$ 37,616.00$ & $26 \%$ & 2.5 & $26 \%$ & $\$ 69,743.00$ & $29 \%$ \\
\hline & & & & & & & 2011 & 1.7 & $14 \%$ & $\$ 44,296.00$ & $25 \%$ & 2.5 & $29 \%$ & $\$ 79,634.00$ & $28 \%$ \\
\hline Ottawa & Le St-Denis & Vanier & $\begin{array}{c}2007 \text { (City of Ottawa, } \\
\text { 2007) }\end{array}$ & 505 & 0103.00 & $\begin{array}{l}1986- \\
2011\end{array}$ & 1986 & 2.4 & $6 \%$ & $\$ 25,315.00$ & $35 \%$ & 2.6 & $16 \%$ & $\$ 37,994.00$ & $35 \%$ \\
\hline
\end{tabular}




\begin{tabular}{|c|c|c|c|c|c|c|c|c|c|c|c|c|c|c|c|}
\hline & & & & & & & 1991 & 2.2 & $8 \%$ & $\$ 31,567.00$ & $38 \%$ & 2.5 & $18 \%$ & $\$ 49,407.00$ & $36 \%$ \\
\hline & & & & & & & 1996 & 2.3 & $8 \%$ & $\$ 31,393.00$ & $36 \%$ & 2.6 & $20 \%$ & $\$ 50,804.00$ & $34 \%$ \\
\hline & & & & & & & 2001 & 2.1 & $9 \%$ & $\$ 35,751.00$ & $34 \%$ & 2.5 & $23 \%$ & $\$ 62,130.00$ & $33 \%$ \\
\hline & & & & & & & 2006 & 1.9 & $19 \%$ & $\$ 45,178.00$ & $32 \%$ & 2.5 & $26 \%$ & $\$ 69,743.00$ & $29 \%$ \\
\hline & & & & & & & 2011 & 1.9 & $19 \%$ & $\$ 45,178.00$ & $32 \%$ & 2.5 & $29 \%$ & $\$ 79,634.00$ & $28 \%$ \\
\hline \multirow[t]{5}{*}{ Hamilton } & $\begin{array}{l}\text { Stinson School } \\
\text { Lofts }\end{array}$ & Stinson & $\begin{array}{c}2010 \text { (City of } \\
\text { Hamilton, 2010b) }\end{array}$ & 537 & 0035.00 & $\begin{array}{l}1991- \\
2011\end{array}$ & 1991 & 2 & $7 \%$ & $\$ 22,658.00$ & $38 \%$ & 2.6 & $8 \%$ & $\$ 40,249.00$ & $33 \%$ \\
\hline & & & & & & & 1996 & 1.9 & $7 \%$ & $\$ 21,295.00$ & $37 \%$ & 2.6 & $9 \%$ & $\$ 41,248.00$ & $32 \%$ \\
\hline & & & & & & & 2001 & 1.9 & $9 \%$ & $\$ 20,743.00$ & $36 \%$ & 2.6 & $10 \%$ & $\$ 47,855.00$ & $30 \%$ \\
\hline & & & & & & & 2006 & 1.9 & $10 \%$ & $\$ 31,960.00$ & $34 \%$ & 2.5 & $13 \%$ & $\$ 55,312.00$ & $27 \%$ \\
\hline & & & & & & & 2011 & 1.8 & $14 \%$ & $\$ 24,755.00$ & $32 \%$ & 2.5 & $15 \%$ & $\$ 60,259.00$ & $25 \%$ \\
\hline \multirow[t]{4}{*}{ Hamilton } & The Connolly & $\begin{array}{l}\text { James Street } \\
\text { South }\end{array}$ & $\begin{array}{c}2015 \text { (City of } \\
\text { Hamilton, 2015a) }\end{array}$ & 537 & 0037.00 & $\begin{array}{l}1996- \\
2011\end{array}$ & 1996 & 1.3 & $15 \%$ & $\$ 13,750.00$ & $35 \%$ & 2.6 & $9 \%$ & $\$ 41,248.00$ & $32 \%$ \\
\hline & & & & & & & 2001 & 1.3 & $21 \%$ & $\$ 15,821.00$ & $33 \%$ & 2.6 & $10 \%$ & $\$ 47,855.00$ & $30 \%$ \\
\hline & & & & & & & 2006 & 1.3 & $27 \%$ & $\$ 18,368.00$ & $35 \%$ & 2.5 & $13 \%$ & $\$ 55,312.00$ & $27 \%$ \\
\hline & & & & & & & 2011 & 1.3 & $29 \%$ & $\$ 18,294.00$ & $35 \%$ & 2.5 & $15 \%$ & $\$ 60,259.00$ & $25 \%$ \\
\hline \multirow[t]{3}{*}{ Hamilton } & Allenby Lofts & Kirkendall & $\begin{array}{c}2002 \text { (City of } \\
\text { Hamilton, 2002) }\end{array}$ & 537 & 0042.00 & $\begin{array}{l}1981- \\
2011\end{array}$ & 1981 & 2.5 & $6 \%$ & $\$ 18,441.00$ & $28 \%$ & 2.8 & $5 \%$ & $\$ 21,766.00$ & $28 \%$ \\
\hline & & & & & & & 1986 & 2.4 & $10 \%$ & $\$ 26,847.00$ & $32 \%$ & 2.7 & $7 \%$ & $\$ 30,558.00$ & $30 \%$ \\
\hline & & & & & & & 1991 & 2.2 & $12 \%$ & $\$ 32,066.00$ & $35 \%$ & 2.6 & $8 \%$ & $\$ 40,249.00$ & $33 \%$ \\
\hline
\end{tabular}




\begin{tabular}{|c|c|c|c|c|c|c|c|c|c|c|c|c|c|c|c|}
\hline & & & & & & & 1996 & 2.3 & $15 \%$ & $\$ 33,946.00$ & $38 \%$ & 2.6 & $9 \%$ & $\$ 41,248.00$ & $32 \%$ \\
\hline & & & & & & & 2001 & 2.2 & $17 \%$ & $\$ 46,073.00$ & $36 \%$ & 2.6 & $10 \%$ & $\$ 47,855.00$ & $30 \%$ \\
\hline & & & & & & & 2006 & 2.2 & $24 \%$ & $\$ 53,522.00$ & $35 \%$ & 2.5 & $13 \%$ & $\$ 55,312.00$ & $27 \%$ \\
\hline & & & & & & & 2011 & 2.1 & $26 \%$ & $\$ 52,376.00$ & $35 \%$ & 2.5 & $15 \%$ & $\$ 60,259.00$ & $25 \%$ \\
\hline \multirow[t]{4}{*}{ Hamilton } & $\begin{array}{l}\text { Gibson School } \\
\text { Lofts }\end{array}$ & Gibson & $\begin{array}{c}2015 \text { (City of } \\
\text { Hamilton, 2015b) }\end{array}$ & 537 & 0061.00 & $\begin{array}{l}1996- \\
2011\end{array}$ & 1996 & 2.6 & $3 \%$ & $\$ 24,302.00$ & $34 \%$ & 2.6 & $9 \%$ & $\$ 41,248.00$ & $32 \%$ \\
\hline & & & & & & & 2001 & 2.8 & $1 \%$ & $\$ 30,284.00$ & $32 \%$ & 2.6 & $10 \%$ & $\$ 47,855.00$ & $30 \%$ \\
\hline & & & & & & & 2006 & 2.6 & $5 \%$ & $\$ 37,498.00$ & $28 \%$ & 2.5 & $13 \%$ & $\$ 55,312.00$ & $27 \%$ \\
\hline & & & & & & & 2011 & 2.5 & $6 \%$ & $\$ 39,486.00$ & $27 \%$ & 2.5 & $15 \%$ & $\$ 60,259.00$ & $25 \%$ \\
\hline \multirow[t]{5}{*}{ Hamilton } & $\begin{array}{l}\text { The Witton } \\
\text { Lofts }\end{array}$ & Central & $\begin{array}{c}2011 \text { (City of } \\
\text { Hamilton, 2012) }\end{array}$ & 537 & 0064.00 & $\begin{array}{l}1991- \\
2011\end{array}$ & 1991 & 2.7 & $3 \%$ & $\$ 25,468.00$ & $31 \%$ & 2.6 & $8 \%$ & $\$ 40,249.00$ & $33 \%$ \\
\hline & & & & & & & 1996 & 2.6 & $6 \%$ & $\$ 23,127.00$ & $33 \%$ & 2.6 & $9 \%$ & $\$ 41,248.00$ & $32 \%$ \\
\hline & & & & & & & 2001 & 2.5 & $3 \%$ & $\$ 27,056.00$ & $32 \%$ & 2.6 & $10 \%$ & $\$ 47,855.00$ & $30 \%$ \\
\hline & & & & & & & 2006 & 2.4 & $11 \%$ & $\$ 37,772.00$ & $32 \%$ & 2.5 & $13 \%$ & $\$ 55,312.00$ & $27 \%$ \\
\hline & & & & & & & 2011 & 2.3 & no NHS? & no NHS? & $28 \%$ & 2.5 & $15 \%$ & $\$ 60,259.00$ & $25 \%$ \\
\hline \multirow[t]{4}{*}{ Hamilton } & $\begin{array}{c}\text { Dundas District } \\
\text { Lofts }\end{array}$ & Dundas & $\begin{array}{c}2010 \text { (City of } \\
\text { Hamilton, 2010a) }\end{array}$ & 537 & 0133.02 & $\begin{array}{l}1991- \\
2011\end{array}$ & 1991 & 2.7 & $13 \%$ & $\$ 47,952.00$ & $36 \%$ & 2.6 & $8 \%$ & $\$ 40,249.00$ & $33 \%$ \\
\hline & & & & & & & 1996 & 2.7 & $16 \%$ & $\$ 53,862.00$ & $33 \%$ & 2.6 & $9 \%$ & $\$ 41,248.00$ & $32 \%$ \\
\hline & & & & & & & 2001 & 2.8 & $20 \%$ & $\$ 65,008.00$ & $29 \%$ & 2.6 & $10 \%$ & $\$ 47,855.00$ & $30 \%$ \\
\hline & & & & & & & 2006 & 2.7 & $28 \%$ & $\$ 77,068.00$ & $25 \%$ & 2.5 & $13 \%$ & $\$ 55,312.00$ & $27 \%$ \\
\hline
\end{tabular}




\begin{tabular}{|c|c|c|c|c|c|c|c|c|c|c|c|c|c|c|c|}
\hline & & & & & & & 2011 & 2.3 & $23 \%$ & $\$ 69,644.00$ & $22 \%$ & 2.5 & $15 \%$ & $\$ 60,259.00$ & $25 \%$ \\
\hline \multirow[t]{7}{*}{ Hamilton } & $\begin{array}{c}\text { Waterdown } \\
\text { District High } \\
\text { School }\end{array}$ & Waterdown & $\begin{array}{c}2001 \text { (City of } \\
\text { Hamilton, 2001) }\end{array}$ & 537 & 0140.04 & $\begin{array}{l}1981- \\
2011\end{array}$ & 1981 & 2.9 & $8 \%$ & $\$ 25,990.00$ & $31 \%$ & 2.8 & $5 \%$ & $\$ 21,766.00$ & $28 \%$ \\
\hline & & & & & & & 1986 & 2.9 & $8 \%$ & $\$ 39,941.00$ & $34 \%$ & 2.7 & $7 \%$ & $\$ 30,558.00$ & $30 \%$ \\
\hline & & & & & & & 1991 & 2.9 & $10 \%$ & $\$ 56,850.00$ & $35 \%$ & 2.6 & $8 \%$ & $\$ 40,249.00$ & $33 \%$ \\
\hline & & & & & & & 1996 & 3 & $15 \%$ & $\$ 63,876.00$ & $38 \%$ & 2.6 & $9 \%$ & $\$ 41,248.00$ & $32 \%$ \\
\hline & & & & & & & 2001 & no census & no census & no census & $\begin{array}{c}\text { no } \\
\text { census }\end{array}$ & 2.6 & $10 \%$ & $\$ 47,855.00$ & $30 \%$ \\
\hline & & & & & & & 2006 & 2.9 & $34 \%$ & $\$ 91,384.00$ & $30 \%$ & 2.5 & $13 \%$ & $\$ 55,312.00$ & $27 \%$ \\
\hline & & & & & & & 2011 & 2.8 & $23 \%$ & $\$ 98,691.00$ & $26 \%$ & 2.5 & $15 \%$ & $\$ 60,259.00$ & $25 \%$ \\
\hline \multirow[t]{6}{*}{ Hamilton } & $\begin{array}{l}\text { St. Thomas } \\
\text { Lofts }\end{array}$ & Waterdown & $\begin{array}{c}2008 \text { (City of } \\
\text { Hamilton, 2008) }\end{array}$ & 537 & 0140.04 & $\begin{array}{l}1986- \\
2011\end{array}$ & 1986 & 2.9 & $8 \%$ & $\$ 39,941.00$ & $34 \%$ & 2.7 & $7 \%$ & $\$ 30,558.00$ & $30 \%$ \\
\hline & & & & & & & 1991 & 2.9 & $10 \%$ & $\$ 56,850.00$ & $35 \%$ & 2.6 & $8 \%$ & $\$ 40,249.00$ & $33 \%$ \\
\hline & & & & & & & 1996 & 3 & $15 \%$ & $\$ 63,876.00$ & $38 \%$ & 2.6 & $9 \%$ & $\$ 41,248.00$ & $32 \%$ \\
\hline & & & & & & & 2001 & no census & no census & no census & $\begin{array}{c}\text { no } \\
\text { census }\end{array}$ & 2.6 & $10 \%$ & $\$ 47,855.00$ & $30 \%$ \\
\hline & & & & & & & 2006 & 2.9 & $34 \%$ & $\$ 91,384.00$ & $30 \%$ & 2.5 & $13 \%$ & $\$ 55,312.00$ & $27 \%$ \\
\hline & & & & & & & 2011 & 2.8 & $23 \%$ & $\$ 98,691.00$ & $26 \%$ & 2.5 & $15 \%$ & $\$ 60,259.00$ & $25 \%$ \\
\hline
\end{tabular}




\section{BIBLIOGRAPHY}

Abramowicz, E. (2014). Trends in adaptive reuse in Toronto (Unpublished primary research for PL8105). Ryerson University, Toronto.

Amayu, E. (2014). New uses for old churches: An examination of the effects of planning regulations on the adaptive reuse of church buildings (Master's report). Retrieved from Queen's University SURP Student Master's Theses and Reports: 2010-2014.

Archer, L. (2009). Save our (heritage) schools: The adaptive reuse of our dying institutional buildings. Spacing Toronto. Retrieved from http://spacing.ca/toronto/2009/04/20/save-our-heritage-schools-the-adaptive-reuse-of-our-dying-institutional-buildings/.

Arnold, S. (2016). Heritage panel places hurdle before Stinson condo project. Hamilton Spectator. Retrieved from http://www.thespec.com/news-story/6407902-heritagepanel-places-hurdle-before-stinson-condo-project/.

Artscape. (2013). Repurposing schools as cultural spaces [press release]. Retrieved from http://www.torontoartscape.org/sites/default/files/News\%20Release_Repurposing $\% 20$ Schools\%20as\%20Cultural\%20Spaces_FINAL.pdf.

Bain, A. (2010). Re-Imaging, Re-Elevating, and Re-Placing the Urban: The Cultural Transformation of the Inner City in the 20-First Century. In T. Bunting, P. Fillion \& R. Walker (Eds.), Canadian Cities in Transition: New Directions in the 20First Century (4th ed.) (262-75). Toronto: Oxford University Press.

Beaudry, G. (2015, Dec. 01). Top 15 des plus belles églises converties à Montréal. Mes Quartiers. Retrieved from https://mesquartiers.wordpress.com/2015/12/01/top-15des-plus-belles-eglises-converties-a-montreal/.

Bentley Mays, J. (2009, Dec. 03). Harry Stinson goes back to school. The Globe and Mail. Retrieved from http://www.theglobeandmail.com/life/home-andgarden/real-estate/harry-stinson-goes-back-to-school/article4294639/.

Bentley Mays, J. (2014, Nov. 06). This church conversion has form and function preserved. The Globe and Mail. Retrieved from http://www.theglobeandmail.com/life/home-and-garden/architecture/this-churchconversion-has-form-and-function-preserved/article21475608/.

Bullen, P. A., \& Love, P. E. D. (2010). The rhetoric of adaptive reuse or reality of demolition: Views from the field. Cities, 27(4), 215-24.

Bullen, P. A., \& Love, P. E. D. (2011a). Adaptive reuse of heritage buildings. Structural Survey, 29(5), 411-21. 
Bullen, P. A., \& Love, P. E. D. (2011b). Factors influence the adaptive re-use of buildings. Journal of Engineering, Design and Technology, 9(1), 32-46.

Bullen, P. A., \& Love, P. E. D. (2011c). A new future for the past: A model for adaptive reuse decision-making. Built Environment Project and Asset Management, 1(1), $32-44$.

Bunting, T. \& Phipps, A. (1988). Inner-city home renovation in two medium-sized Canadian cities: A case of modest upgrading. In T. Bunting \& P. Fillion (Eds.), The Changing Canadian Inner City (137-57). Waterloo: University of Waterloo Department of Geography.

Button, J. (2009). The reuse of surplus school sites in Ottawa, Ontario: An examination of community interests and public participation in the acquisition, planning and conversion of surplus school sites (Master's report). Retrieved from Queen's University SURP Student Master's Theses and Reports: 2005-2009.

Campion-Smith, B. (2015, Nov. 05). Canada's long-form census is back for 2016. Toronto Star. Retrieved from http://www.thestar.com/news/canada/2015/11/05/liberals-restore-mandatory-longform-census.html.

Canadian Mortgage and Housing Corporation. (2006, July 18). Downtown church converted into affordable housing. Canadian Mortgage News. Retrieved from http://archive.canequity.com/mortgage-news/archive/2006/pdf/2006-0718_CMHC-downtown_church_converted_housing.pdf.

Caulfield, J. (1994). City form and everyday life: Toronto's gentrification and critical social practice. Toronto: University of Toronto Press.

Caulfield, J. (2015, April 22). Condo developers covet churches for conversion. Building Design + Construction. Retrieved from http://www.bdcnetwork.com/condodevelopers-covet-churches-conversions.

CBC News. (2010, June 29). Old Firehall gets new community centre. Canadian Broadcasting Corporation. Retrieved from http://www.cbc.ca/news/canada/ottawa/old-firehall-gets-new-community-centre1.971647.

Chook, S. J. (2011). Adaptive reuse of office space to residential units in Kingston, Ontario (Master's report). Retrieved from Queen's University SURP Student Master's Theses and Reports: 2010-2014.

City of Hamilton. (2001). Report 01-023 - 4:30pm, Tuesday July 10, 2001. Committee of the Whole Report. Retrieved from 
http://www2.hamilton.ca/Hamilton.Portal/Inc/PortalPDFs/ClerkPDFs/committeeof-the-whole/2001/jul10/Rep01-023.pdf.

City of Hamilton. (2002). Application for a Change in Zoning for 357 Hunter Street West (former City of Hamilton). Planning and Development Department Report.

Retrieved from

http://www2.hamilton.ca/Hamilton.Portal/Inc/PortalPDFs/ClerkPDFs/committeehearings/2002/May08/PD02088\%20.pdf.

City of Hamilton. (2008). Application for a Change in Zoning for the Properties Located at 40 and 46 Flamboro Street and 62 Barton Street (Flamborough). Planning and Economic Development Department Report. Retrieved from http://www2.hamilton.ca/NR/rdonlyres/C8459A37-36B5-4274-B6A77EC9A80CC8FD/0/Feb05PED08035.pdf.

City of Hamilton. (2009). Urban Hamilton Official Plan. Retrieved from City of Hamilton City Planning: https://www.hamilton.ca/city-planning/official-planzoning-by-law/urban-hamilton-official-plan.

City of Hamilton. (2010a). Application for an Amendment to the Town of Dundas Official Plan and Zoning By-law No. 3581-86 for the Lands Located at 365 Park Street West and 397 King Street West (Dundas). Planning and Economic Development Department Report. Retrieved from http://www2.hamilton.ca/NR/rdonlyres/7628D349-011F-45B0-ABEF9C27EE820A03/0/Ju105PED10142.pdf.

City of Hamilton. (2010b). Application for Approval of an Amendment to the City of Hamilton Zoning By-law No. 6593 for the Lands Located at 200 Stinson Street (Hamilton). Planning and Economic Development Department Report. Retrieved from http://www2.hamilton.ca/NR/rdonlyres/3354BC3F-C2DD-4498-BF26174DDF63197F/0/Aug09PED10152.pdf.

City of Hamilton. (2012). Hamilton Downtown Property Improvement Grant Program 50 Murray Street West. Planning and Development Department Report. Retrieved from http://www2.hamilton.ca/NR/rdonlyres/0D4E72C2-8C21-453A-8740B7FF341AAAFC/0/Mar21EDRMS_n281711_v1_5_6_PED12031.pdf.

City of Hamilton. (2015a). Planning Committee Minutes 15-001. Committee Minutes. Retrieved from http://www2.hamilton.ca/NR/rdonlyres/A0F1ADC4-7FF8-40AA8273-394A279C42EA/0/Jan13PlanningMinutes15001.pdf.

City of Hamilton. (2015b). Planning Committee Minutes 15-012. Committee Minutes. Retrieved from http://www2.hamilton.ca/CityDepartments/CorporateServices/Clerks/AgendaMin utes/MinutesReports/Planning/2015/Aug11PlanningMinutes15012.pdf. 
City of Ottawa. (2003). Official Plan. Retrieved from City of Ottawa Planning and Development: http://ottawa.ca/en/official-plan-0/volume-1-official-plan/pdfversion.

City of Ottawa. (2007). Zoning - 345 St. Denis Street. Planning and Environment Committee Report. Retrieved from http://app06.ottawa.ca/calendar/ottawa/citycouncil/occ/2008/01-09/ACS2007PTE-APR-0217.htm.

City of Toronto. (2001a). Final Report - 70 High Park Avenue; Application to amend the former City of Toronto Official Plan and Zoning By-law No. 438-86; The Trustees of the Fifth Church of Christ, Scientist (Parkdale-High Park, Ward 13). Staff Report. Retrieved from http://www.toronto.ca/legdocs/2001/agendas/council/cc011204/yk10rpt/cl004.pdf

City of Toronto. (2001b). Draft By-laws - Official Plan Amendment and Rezoning - 662 Pape Avenue. City Clerk Report. Retrieved from http://www.toronto.ca/legdocs/2001/agendas/council/cc010626/to5rpt/c1004.pdf.

City of Toronto. (2002). 384 Sunnyside Avenue (Howard Park Methodist Church) Inclusion on the City of Toronto Inventory of Heritage Properties. Staff Report. Retrieved from http://www.toronto.ca/legdocs/2003/agendas/committees/yk/yk030121/it042.pdf.

City of Toronto. (2007). 701-703 Dovercourt Road - Official Plan and Zoning By-law Amendment Applications - Final Report. Staff Report. Retrieved from http://www.toronto.ca/legdocs/mmis/2007/te/bgrd/backgroundfile-5978.pdf.

City of Toronto. (2008a). 21 Swanwick Ave-OPA \& Rezoning - Final Report. Staff Report. Retrieved from http://www.toronto.ca/legdocs/mmis/2008/te/bgrd/backgroundfile-14171.pdf.

City of Toronto. (2008b). 152 Annette Street (Victoria Royce Church) - Approval of Alterations to a Heritage Property and Intention to Designate, Part IV, Section 29, Ontario Heritage Act. Staff Report. Retrieved from http://www.toronto.ca/legdocs/mmis/2008/ey/bgrd/backgroundfile-16620.pdf.

City of Toronto. (2009a). 34-38 Hazelton Avenue, Alteration to a Designated Heritage Property. Staff Report. Retrieved from http://www.toronto.ca/legdocs/mmis/2009/te/bgrd/backgroundfile-20287.pdf.

City of Toronto. (2009b). 506 College Street - Designation under Part IV, Section 29 of the Ontario Heritage Act and Authority to Enter into a Heritage Easement Agreement. Staff Report. Retrieved from http://www.toronto.ca/legdocs/mmis/2009/te/bgrd/backgroundfile-21950.pdf. 
City of Toronto. (2010a). 169 and 175 Jones Avenue - OPA \& Rezoning, Site Plan, Applications - Final Report. Staff Report. Retrieved from http://www.toronto.ca/legdocs/mmis/2010/te/bgrd/backgroundfile-31095.pdf.

City of Toronto. (2010b). 200 Annette Street - Alteration to a Heritage Property and Intention to Designate, Part IV, Section 29, Ontario Heritage Act and Authority to Enter Into a Heritage Easement Agreement. Staff Report. Retrieved from http://www.toronto.ca/legdocs/mmis/2010/pb/bgrd/backgroundfile-32023.pdf.

City of Toronto. (2012a). 129 St Clair Ave. West \& Part of 111 St. Clair Ave. WestOfficial Plan and Zoning Amendment Applications - Final Report. Staff Report. Retrieved from http://www.toronto.ca/legdocs/mmis/2012/te/bgrd/backgroundfile-44834.pdf.

City of Toronto. (2012b). 40-42 Westmoreland - Request for Direction to Amend a Section 37 Agreement. Staff Report. Retrieved from http://www.toronto.ca/legdocs/mmis/2012/te/bgrd/backgroundfile-45946.pdf.

City of Toronto. (2012c). 243 Perth Ave - Official Plan Amendment and Zoning Amendment Applications - Final Report. Staff Report. Retrieved from http://www.toronto.ca/legdocs/mmis/2012/te/bgrd/backgroundfile-49209.pdf.

City of Toronto. (2012d). 1183 Dufferin Street Official Plan Amendment and Zoning Amendment Applications - Preliminary Report. Staff Report. Retrieved from http://www.toronto.ca/legdocs/mmis/2012/te/bgrd/backgroundfile-50235.pdf.

City of Toronto. (2015). Official Plan. Retrieved from City of Toronto City Planning: http://www1.toronto.ca/wps/portal/contentonly?vgnextoid=03eda07443f36410Vg nVCM10000071d60f89RCRD.

Clandfield, D. (2010). The school as community hub: A public alternative to the neoliberal threat to Ontario schools. Our Schools, Our Selves, 19(4), 7-74.

Clay, P. (1979). Neighbourhood renewal: Middle-class resettlement and incumbent upgrading in American neighbourhoods. Lexington, MA: D. C. Health.

Cornell, C. (2016, Jan. 24). Startup boom revitalizing urban Kitchener, but not all in favour. The Globe and Mail. Retrieved from http://www.theglobeandmail.com/report-on-business/smallbusiness/startups/startup-boom-is-revitalizing-urban-kitchener-but-not-everyoneis-happy/article28366204/.

Dantas, A. (1988). Overspill as an alternative style of gentrification: The case of Riverdale, Toronto. In T. Bunting \& P. Fillion (Eds.), The Changing Canadian Inner City (73-86). Waterloo: University of Waterloo Department of Geography. 
Davidson, M. \& Lees, L. (2005). New-build 'gentrification' and London's riverside renaissance. Environment and Planning, 37, 1165-90.

Dean, C., Donnellan, C. \& Pratt, A. (2010). Tate Modern: Pushing the limits of regeneration. City, Culture and Society, 1, 79-87.

Dutton, P. (2005). Outside the metropole: Gentrification in provincial cities or provincial gentrification? In R. Atkinson and G. Bridge (Eds.), Gentrification in a Global Context: The new urban colonialism, (214-29). New York: Routledge.

Fagan, N. (2010, Mar. 17). Report on Ottawa's neighbourhood associations: Their power and influence. Daily Xtra. Retrieved from http://www.dailyxtra.com/ottawa/newsand-ideas/news/report-ottawas-neighbourhood-associations-power-and-influence6587.

Gale, D. E. (1979). Middle class resettlement in older urban neighbourhoods: The evidence and the implications. Journal of the American Planning Association, 45, 293-204.

Gee, M. (2015, Jan. 02). How Hamilton is revitalizing its downtown to bring new life. The Globe and Mail. Retrieved from http://www.theglobeandmail.com/news/toronto/building-blocks-for-a-newhamilton-already-in-place/article22279390/.

Glancey, J. (2014, Mar. 23). Danish National Maritime Museum in Helsingor, Denmark by Bjarke Ingels Group. Architectural Review. Retrieved from http://www.architectural-review.com/today/danish-national-maritime-museum-inhelsingr-denmark-by-bjarke-ingels-group/8660485.fullarticle.

Glass, R. (1964). Introduction: Aspects of Change. In Centre for Urban Studies (Ed.), London: Aspects of Change. London: MacKibbon and Kee.

Hackworth, J. (2002). Postrecession gentrification in New York City. Urban Affairs Review, 37(6), 815-43.

Hackworth, J. \& Gullikson, E. (2013). Giving new meaning to religious conversion: Churches, redevelopment and secularization in Toronto. The Canadian Geographer, 57(1), 72-89.

Hamilton Public Library. (2016). Resources - Directories: City Directories. Retrieved from http://www.hpl.ca/articles/city-directories.

Harness, A. (2013, Feb. 15). House of the Week. Toronto Star. Retrieved from http://www.thestar.com/life/homes/2013/02/15/little_italy_condo_built_around_1 884_church.html. 
Hulchanski, D., Murdie, R., Walks, A. \& Bourne, L. (2013, Oct. 4). Canada's voluntary census is worthless. Here's why. The Globe and Mail. Retrieved from http://www.theglobeandmail.com/opinion/canadas-voluntary-census-is-worthlessheres-why/article14674558/.

Hutton, S. (2014). From old mould to functional gold: The adaptive reuse of surplus heritage schools in Hamilton, Ontario (Master's report). Retrieved from the Queen's University SURP Student Master's Theses and Reports: 2010-2014.

Karsten, L. (2014). From yuppies to yupps: Family gentrifiers consuming spaces and reinventing cities. Tijdschrift voor Economische en Sociale Geografie, 105(2), 17588.

Kary, K. J. (1988). The gentrification of Toronto and the rent gap theory. In T. Bunting \& P. Fillion (Eds.), The Changing Canadian Inner City (53-72). Waterloo: University of Waterloo Department of Geography.

Keil, R. (2002). "Common-Sense" neoliberalism: Progressive conservative urbanism in Toronto, Canada. Antipode, 34(3), 578-601.

Kulig, P. (2010). High-end condo goes back to school. Toronto Star. Retrieved from http://www.thestar.com/life/homes/2010/03/20/highend_condo_goes_back_to_sc hool.html.

Langston, C., Wong, F. K. W., Hui, E. C. M., \& Shen, L. (2007). Strategic assessment of building adaptive reuse opportunities in Hong Kong. Building and Environment, 43, 1709-18.

Lees, L., Slater, T. \& Wyly, E. (2008). Gentrification [e-reader version]. New York: Routledge.

Lehrer, U. \& Wieditz, T. (2009). Condominium development and gentrification: The relationship between policies, building activities and socio-economic development in Toronto. Canadian Journal of Urban Research, 18(1), 140-61.

Ley, D. (1986). Alternative explanations for inner-city gentrification: A Canadian assessment. Annals of the Association of American Geographers, 76(4), 521-35.

Ley, D. \& Martin, R. B. (1993). Gentrification as secularization: The status of religious belief in the post-industrial city. Social Compass, 40(2), 217-32.

Lynch, N. A. (2013). Altared Places: The re-use of urban churches as loft living in the post-secular and post-industrial city (Ph.D. Thesis). Retrieved from cIRcle at the University of British Columbia. 
MacDonald, G. (2013, Feb. 09). Bridgepoint Hospital shines light on a dark past. The Globe and Mail. Retrieved from http://www.theglobeandmail.com/news/toronto/bridgepoint-hospital-shines-lighton-a-dark-past/article8407192/.

Mills, C. (2014). Hintonburg 17-storey development rezoning endorsed by city staff. Ottawa Citizen. Retrieved from http://ottawacitizen.com/news/localnews/hintonburg-17-storey-development-rezoning-endorsed-by-city-staff.

Musée d'Orsay. (2006). From station to museum. Retrieved from http://www.museeorsay.fr/en/collections/history-of-the-museum/from-station-to-museum.html.

Ngoh, J. (2009, June 10). Condo of the week: Archive Square at 174 Stanley. Ottawa Condos Blog. Retrieved from http://ottawacondos.blogspot.ca/2009/06/condo-ofweek-archive-square-at-174.html.

O'Reilly, D. (2012, Aug. 03). Harry Stinson goes back to school. Toronto Star. Retrieved from http://www.thestar.com/life/homes/2012/08/03/harry_stinson_goes_back_to_scho ol.html.

Ottawa Condo Network. (2014a). 159 Murray - Ecole Guigues. Retrieved from http://www.ottawacondonetwork.com/authentic/159-murray-ecole-guigues/.

Ottawa Condo Network (2014b). 24 Springfield - Schoolhouse Square. Retrieved from http://www.ottawacondonetwork.com/authentic/24-springfield-schoolhousesquare/.

Ottawa Condo Network (2014c). 297 Dupuis - Les Lofts du Montfort. Retrieved from http://www.ottawacondonetwork.com/authentic/297-dupuis-les-lofts-dumontfort/.

Ottawa Condo Network (2014d). 19 Melrose-Ecole Sacre-Coeur. Retrieved from http://www.ottawacondonetwork.com/authentic/19-melrose-ecole-sacre-coeur/.

Phipps, A. (2008). Reuses of closed schools in Windsor, Ontario. Socio-Economic Planning Sciences, 42, 18-30.

Province of Ontario. (2014). 2014 Provincial Policy Statement. Retrieved from the Ministry of Municipal Affairs and Housing: http://www.mah.gov.on.ca/AssetFactory.aspx?did=10463.

Quadrangle Architects. (2016). Expertise - Specialisms: Adaptive Reuse. Retrieved from http://www.quadrangle.ca/expertise/specialisms/adaptive-reuse/. 
Radburn, M. (2011, Feb. 22). Quartier Vanier: Nowhere to go but up? Capital Arts. Retrieved from http://www.cusjc.ca/capitalarts/?p=2467.

Revitalization of Kitchener's east downtown area a welcome development. [Editorial]. (2012, Oct. 09). Waterloo Region Record. Retrieved from http://www.therecord.com/opinion-story/2613818-opinion-revitalization-ofkitchener-s-east-downtown-area-a-welcome-development/.

Robertson Simmons Architects. (2016). New Work: Google Kitchener Office. Retrieved from http://www.rsarchitects.ca/new-work-google-kitchener-office-25-breithauptstreet.htm.

Rose, D. (2010). Rethinking gentrification: Beyond the uneven development of Marxist urban theory. In J. Brown-Saracino (Ed.), The gentrification debates, (195-210). New York: Routledge.

Rushowy, K. \& Brown, L. (2015, January 21). Revealed: 'Secret' list of Toronto schools that could close or have boundary changes. Toronto Star. Retrieved from http://www.thestar.com/yourtoronto/education/2015/01/31/revealed-secret-list-oftargeted-toronto-schools-that-could-close-or-have-boundary-changes.html.

Sauve, L. (2014). An investigation into the role for municipal planners in decisions pertaining to the future of surplus schools (Major research paper). Retrieved from Digital Commons@Ryerson: Theses and dissertations.

Sewell, J. (1993). The shape of the city. Toronto: University of Toronto Press.

Shaw, W. (2005). Heritage and gentrification: Remembering the 'good old days' in postcolonial Sydney. In R. Atkinson \& G. Bridge (Eds.), Gentrification in a global context: The new urban colonialism, (58-72). New York: Routledge.

Shipley, R. \& Kovacs, J. (2007). From bottles to buildings. Alternatives, 33(2/3), 11.

Shipley, R., Utz, S. \& Parsons, M. (2006). Does adaptive reuse pay? A study of the business of building renovation in Ontario, Canada. International Journal of Heritage Studies, 12(6): 505-20.

Smith, N. (1979). Toward a theory of gentrification: A back to the city movement by capital, not people. Journal of the American Planning Association, 45(4), 538-48.

Smith, N., Duncan, B. \& Reid, L. (1989). From disinvestment to reinvestment: Tax arrears and turning points in the East Village. Housing Studies, 4(4), 238-52.

Smith, N. \& Defilippis, J. (1999). The reassertion of economics: 1990s gentrification in the Lower East Side. International Journal of Urban and Regional Research, 23, 638-53. 
Sooley, L. (2012). An examination of the benefits and constraints of adaptive reuse of surplus school sites (Major research paper). Retrieved from Digital Commons @ Ryerson: Theses and dissertations. (Paper 1765)

Spears, T. (2015, Dec. 20). All Saints Anglican Church sold for community use. Ottawa Citizen. Retrieved from http://ottawacitizen.com/news/local-news/all-saintsanglican-church-sold-for-community-use.

Stas, N. (2007). The economics of adaptive reuse of old buildings: A financial feasibility study \& analysis (Master's thesis). Retrieved from ProQuest dissertations publishing. (Paper MR34399)

Statistics Canada (1971-2011). Profile of Census Tracts - Cumulative. Retrieved from http://dc1.chass.utoronto.ca/census/.

Statistics Canada (2011). Population and dwelling counts highlight tables, 2011 census. Retrieved from http://www12.statcan.gc.ca/census-recensement/2011/dp-pd/hltfst/pd-pl/Table-Tableau.cfm? $=301 \& \mathrm{~S}=3 \& \mathrm{O}=\mathrm{D}$.

Toronto Lands Corporation. (2014). FAQ. Retrieved from http://www.torontolandscorp.com/tlc.php/faq/.

Walks, R. A. \& August, M. (2008). The factors inhibiting gentrification in areas with little non-market housing: Policy lessons from the Toronto experience. Urban Studies, 45(12), 2594-2625.

Walks, R. A. \& Maaranen, R. (2008). The timing, patterning and forms of gentrification and upgrading in Montreal, Toronto and Vancouver, 1961 to 2001. Toronto: Centre for Urban and Community Studies, Cities Centre, University of Toronto.

Warzecha, M. (2012a, Oct. 12). Condominium: $\$ 1.2$ million for a sunny unit in a former church in midtown. Toronto Life. Retrieved from http://torontolife.com/realestate/condomonium-11-woodlawn-avenue/.

Warzecha, M. (2012b, Nov. 30). Condominium: \$1.2 million for a suite in a former Sunday school near Dovercourt and Bloor. Toronto Life. Retrieved from http://torontolife.com/real-estate/condomonium-110-hepbourne-street/.

Wells, J. (2013, May 25). Barton Street: Bound for glory or...? Hamilton Spectator. Retrieved from http://www.thespec.com/news-story/3237837-barton-streetbound-for-glory-or-/.

White, M. (2014, Jan. 10). Home of the week: A king of Kensington condos. The Globe and Mail. Retrieved from http://www.theglobeandmail.com/life/home-andgarden/real-estate/home-of-the-week-a-king-of-kensingtoncondos/article $16278739 /$. 
Wiebe, C. \& Quinn, C. (2010). Are Canada's historic schools our next endangered species? Heritage 8(3/4), 20-9.

Wilson, C. A. (2010). Adaptive reuse of industrial buildings in Toronto, Ontario: Evaluating criteria for determining building selection (Master's report). Retrieved from Queen's University SURP Student Master's Theses and Reports: 2010-2014.

Wyly, E. K. \& Hammel, D. J. (1999). Islands of decay in seas of renewal: Housing policy and the resurgence of gentrification. Housing Policy Debate, 10(4), 711-71.

Young, M. (2009). Adapting to adaptive reuse: Comments and concerns about the impacts of a growing phenomenon. Southern California Interdisciplinary Law Journal, 18(3), 703-28.

Zuk, D. (2015). Old buildings, great beer: Lessons of adaptive reuse and microbreweries in the city of Toronto (Master's report). Retrieved from Queen's University SURP Student Master's Theses and Reports: 2015.

Zukin, S. (1982). Loft living: culture and capital in urban change. Baltimore: Johns Hopkins University Press. 